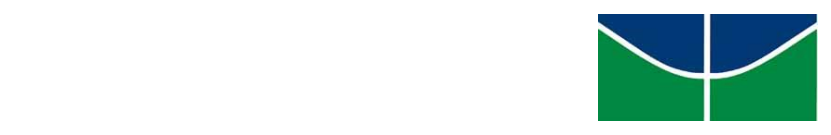

UNIVERSIDADE DE BRASÍLIA - FACULDADE UNB PLANALTINA - FUP PROGRAMA DE PÓS-GRADUAÇÃO EM MEIO AMBIENTE E DESENVOLVIMENTO RURAL - PPG-MADER

CARLA SILVA SOUSA

POLÍTICAS PÚBLICAS PARA A AGRICULTURA FAMILIAR:

UM ESTUDO SOBRE A DESCONTINUIDADE DO PROGRAMA MAIS GESTÃO 
CARLA SILVA SOUSA

\section{POLÍTICAS PÚBLICAS PARA A AGRICULTURA FAMILIAR: UM ESTUDO SOBRE A DESCONTINUIDADE DO PROGRAMA MAIS GESTÃO}

Dissertação de mestrado apresentada ao Programa de Pós-Graduação em Meio Ambiente e Desenvolvimento Rural da Faculdade UnB - Campus Planaltina, como requisito para a obtenção do título de Mestre em Meio Ambiente e Desenvolvimento Rural.

Orientador:

Professor Dr. Mário Lúcio de Avila 
Ficha catalográfica elaborada automaticamente, com os dados fornecidos pelo(a) autor(a)

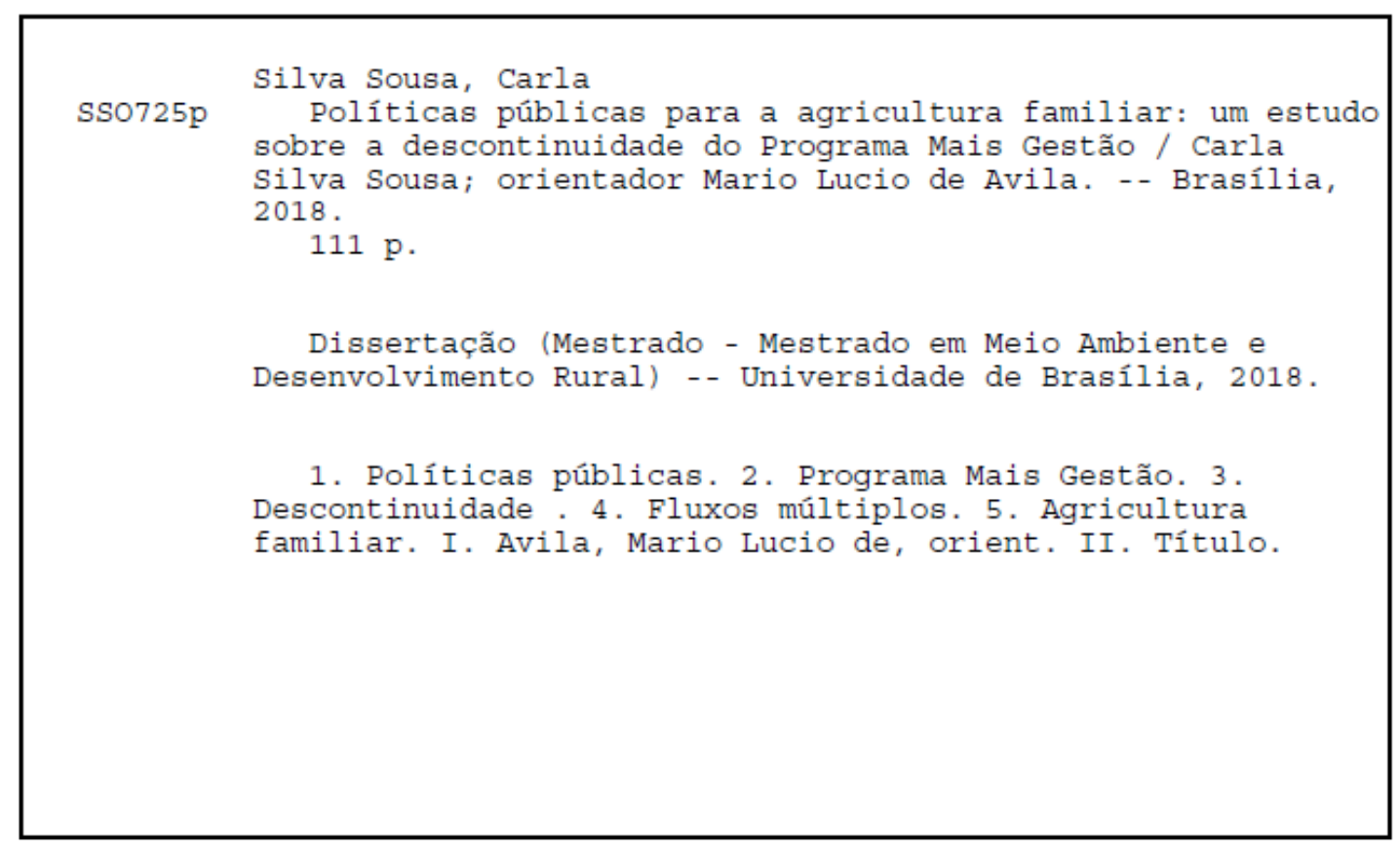


CARLA SILVA SOUSA

\title{
POLÍTICAS PÚBLICAS PARA A AGRICULTURA FAMILIAR: UM ESTUDO SOBRE A DESCONTINUIDADE DO PROGRAMA MAIS GESTÃO
}

\author{
Banca Examinadora
}

Planaltina-DF, 23 de janeiro de 2018

Prof. Dr. Mário Lúcio de Ávila

Orientador

Universidade de Brasília - Faculdade UnB Planaltina

Prof. Dra. Janaína Deane de Abreu Sá Diniz

Membro Interno

Universidade de Brasília - Faculdade UnB Planaltina

Prof. Dra. Carolina Lopes Araújo

Membro Externo ao Programa

Universidade de Brasília - Faculdade UnB Planaltina

Prof. Dr. Marcelo Ximenes Aguiar Bizerril

Examinador Suplente

Universidade de Brasília - Faculdade UnB Planaltina 
É aquela voz que te abraça e te diz que tudo vai passar.

É o que rega a paz pra colher o bem. É aquela verdade que mora no coração. Projota gostaria de acrescentar: foco e força. É aquilo que não se explica (e nem precisa). É o que move um corpo quando fraco. É aquilo que te faz acreditar. É o que não me deixa desistir de lutar. 


\section{AGRADECIMENTOS}

A Deus e Nossa Senhora, por me darem força e iluminarem meus caminhos.

Por mais que a construção de uma dissertação seja um processo solitário, o apoio de algumas pessoas foi fundamental para a conclusão dessa pesquisa. A minha família, meus pais Edival e Orlandina, responsáveis pela minha criação e pelo apoio incondicional. A minhas irmãs Jaqueline e Verônica e meu cunhado Tércio, por todo o exemplo, por me incentivarem e acreditarem que eu seria mestre, antes mesmo de eu imaginar. Ao meu amado Edu. Obrigada por vocês terem compreendido minhas ausências, estresses e por serem mais que minha fortaleza. Amo vocês.

Ao meu orientador, Mario Lucio de Avila, por ter me apresentado o Programa Mais Gestão e me auxiliado a iniciar e fechar esse ciclo. Obrigada por compartilhar seus ensinamentos, orientações precisas e indispensáveis.

Aos membros da banca, professoras Janaína Deane e Carolina Araújo e o professor Marcelo Bizerril, por terem aceitado de pronto compor a banca deste trabalho. Pelas valiosas contribuições que foram dadas desde a qualificação e mesmo após a defesa.

Aos professores, funcionários e colegas do Programa de Pós-Graduação em Meio Ambiente e Desenvolvimento Rural, que compartilharam seus ensinamentos e angústias.

Aos colegas de trabalho do Projeto RADIS, por todo o incentivo, apoio e compreensão.

A Rede de Universidades na Avaliação do Programa Mais Gestão.

Aos colegas de café e chocolate.

Aqueles que por ventura não mencionei e que contribuíram para o desenvolvimento deste trabalho, o meu muito obrigada. 


\section{RESUMO}

Por anos aquém da agenda política, os agricultores familiares conseguiram uma relevância considerável durante os governos federais democráticos. A criação de políticas públicas para esse setor e demais marginalizados, como indígenas, quilombolas e outros, permitiu evoluções para tais classes, além de promover o Brasil a um reconhecimento internacional por conta destas ações. Mudanças, no entanto, ocorreram a partir do ano de 2016, com o impeachment da expresidente Dilma Rousseff. Com a posse do presidente interino Michel Temer, diversas políticas foram afetadas e descontinuadas, a exemplo do Programa Mais Gestão. O Mais Gestão foi criado com o intuito de aperfeiçoar o acesso das cooperativas da agricultura familiar ao Programa de Aquisição de Alimentos (PAA), ao Programa Nacional de Alimentação Escolar (PNAE) e ao Programa Nacional de Produção e Uso do Biodiesel (PNPB), por meio da oferta de Assistência Técnica e Extensão Rural (ATER), com ênfase no coletivo de agricultores. Desde sua criação no ano de 2012, até o ano de 2015, o Programa atendeu mais de 400 cooperativas em quase todas as regiões brasileiras. A presente dissertação buscou apresentar os fluxos múltiplos: político, de problemas e de soluções que culminaram na extinção do Programa Mais Gestão. Para tanto, desenvolveu-se uma pesquisa documental e bibliográfica, que possibilitou a compreensão desta decisão repentina. Além da identificação dos fluxos múltiplos que propiciaram a extinção do Mais Gestão, foi realizada uma análise do PAA, PNAE e PNPB e também a construção do ciclo de vida do Programa Mais Gestão, por meio do ciclo de políticas públicas. Como resultado foi possível observar a mudança de preocupação governamental com a questão e identificar as principais ações usadas para a descontinuidade do PMG. As políticas públicas para a agricultura familiar além de terem seus recursos reduzidos, agora precisam disputar espaço com outras temáticas. As classes marginalizadas perderam espaço na agenda governamental e há uma clara tentativa de incorporação de outras políticas públicas condizentes com a agenda do atual governo.

Palavras-chave: Políticas públicas. Programa Mais Gestão. Descontinuidade. Fluxos múltiplos. Agricultura familiar. 


\begin{abstract}
For years under the political agenda, family farmers have achieved considerable relevance during the democratic federal governments. The creation of public policies for this sector and other marginalized people, such as indigenous people, quilombolas and others, allowed changes to these classes, as well as promoting Brazil to an international recognition for these actions. Changes, however, occurred from the year 2016, with the impeachment of former President Dilma Rousseff. With the interim president's inauguration, Michel Temer, several policies were affected and discontinued, such as the Programa Mais Gestão (PMG). Mais Gestão was created with the aim of improving the access of family farming cooperatives to the Programa de Aquisição de Alimentos (PAA), the Programa Nacional de Alimentação Escolar (PNAE) and the Programa Nacional de Produção e Uso do Biodiesel (PNPB). through the provision of Assistência Técnica e Extensão Rural (ATER), with emphasis on the farmers collective. Since its creation in 2012, through 2015, the Program has served more than 400 cooperatives in almost all Brazilian regions. The present dissertation sought to present the political flows, problems and solutions that culminated in the extinction of the Programa Mais Gestão. Therefore, it was developed a documentary and bibliographical research, that made possible the understanding of the sudden decision. In addition to identifying the multiple flows that led to the extinction of Programa Mais Gestão, an analysis of the PAA, PNAE and PNPB was carried out, as well as the construction of the life cycle of the Programa Mais Gestão through the public policy cycle. As a result, it was possible to identify the change of governmental concern with the issue and to identify the main reasons used to discontinue the PMG. Public policies for family agriculture, in addition to having their resources reduced, now need to compete with other issues. Marginalized classes have lost ground in the government agenda and there is a clear attempt to incorporate other public policies that are aligned with the current government's agenda.
\end{abstract}

Key words: Public policy. Programa Mais Gestão. Discontinuity. Multiple streams. Family farming. 


\section{LISTA DE FIGURAS}

Figura 1 - Dinâmica metodológica e instrumentos de pesquisa. ___ 24

Figura 2 - O ciclo de políticas públicas e suas sete fases. ___ 32

Figura 3 - Dinâmica criada por Capella que exemplifica a criação de uma política pública pela

integração dos fluxos múltiplos criados por Kingdon. 38

Figura 4 - Resumo das três gerações de políticas públicas voltadas para a agricultura familiar, com a ênfase dada em cada geração e os principais programas lançados.

Figura 5 - Evolução de valores das aquisições da agricultura familiar para produção do biodiesel, em milhões de reais.

Figura 6 - Evolução do número de atendimentos de ATER no Brasil

Figura 7 - Faixa de idade das cooperativas atendidas pelo Programa Mais Gestão: até 3 anos; de 4 a 10 anos; de 11 a 25 anos; de 26 a 50 anos e acima de 51 anos.

Figura 8 - Participação dos mercados institucionais no faturamento total (em \%).

Figura 9 - Histórico de adaptação da metodologia PEIEx e contratação das Organizações Não

Governamentais - A Casa Verde e Centro de Apoio a Microempreendedores pelo Ministério do

Desenvolvimento Agrário.

Figura 10 - Matriz lógica geral do Programa Mais Gestão, destacando os objetivos gerais e específicos, metas e produtos.

Figura 11 - Sistemática de funcionamento do Programa Mais Gestão.___ 79

Figura 12 - Quantitativo de sócios, sócios ativos, associados com DAP e sócios ativos com DAP, por região.

Figura 13 - Quantitativo de associados com DAP por região, total x mulheres.

Figura 14 - Porcentagem das cooperativas atendidas pelo Programa Mais Gestão que acessaram a

ATER via entidades públicas. $(\mathrm{N}=443)$.

Figura 15 - Quantidade de cooperativas atendidas pelo Programa Mais Gestão segundo os principais produtos comercializados em 2012. 


\section{LISTA DE QUADROS}

Quadro 1 - Chamadas públicas lançadas pelo MDA para contratação de entidades executoras de ATER, com vistas a executar o Programa Mais Gestão e valores envolvidos.

Quadro 2 - Quantidade de cooperativas e estados beneficiados, por edital.

Quadro 3 - Principais medidas legislativas adotadas pelo Presidente Michel Temer. 


\section{LISTA DE TABELAS}

Tabela 1 - Produção da agricultura familiar de produtos selecionados no ano de 2006

Tabela 2 - Evolução dos recursos SEAD/MDS aplicados na aquisição de produtos do PAA entre 2003

a 2016

Tabela 3 - Evolução da aquisição (valor em mil reais) das modalidades do Programa de Aquisição de Alimentos, dos anos 2009 a 2016.

Tabela 4 - Valores referentes a compra da agricultura familiar no PNAE (total de 4992 municípios). 57

Tabela 5 - Faturamento $(\mathrm{R} \$$ ) das cooperativas atendidas pelo Programa Mais Gestão em diferentes mercados.

Tabela 8 - Síntese dos dados das cooperativas atendidas pelo Programa Mais Gestão. 81

Tabela 7 - Valor de faturamento das cooperativas atendidas pelo Programa Mais Gestão ao PAA, PNAE e PNPB e respectivo número de cooperativas que acessam aos mercados. 83 


\section{LISTA DE SIGLAS E ABREVIATURAS}

AIAF - Ano Internacional da Agricultura Familiar

ANATER - Agência Nacional de Assistência Técnica e Extensão Rural ANP - Agência Nacional do Petróleo, Gás Natural e Biocombustíveis

ATC - Assistente técnico central

ATER - Assistência Técnica e Extensão Rural

ATR - Assistente Técnico Regional

BNDES - Banco Nacional de Desenvolvimento Econômico e Social

CAE - Conselhos de Alimentação Escolar

CAM - Centro de Apoio a Microempreendedores

CDAF - Compra Direta da Agricultura Familiar

CDS - Compra com Doação Simultânea

CEIB - Comissão Executiva Interministerial

CF - Constituição Federal

CGU - Controladoria Geral da União

CNS - Conselho Nacional dos Seringueiros

Conab - Companhia Nacional de Abastecimento

Coomtrata - Cooperativa dos Pequenos Produtores Rurais e Trabalhadores Autônomos na Agropecuária

CUT - Central Única dos Trabalhadores

DAP - Declaração de Aptidão ao Pronaf

DATER - Departamento de Assistência Técnica e Extensão Rural

DEGRAV - Departamento de Geração de Renda e Agregação de Valor

DNTR - Departamento Nacional dos Trabalhadores Rurais

FE - Formação de Estoques

FNDE - Fundo Nacional de Desenvolvimento da Educação 
INCRA - Instituto de Colonização e Reforma Agrária

MAPA - Ministério da Agricultura Pecuária e Abastecimento

MDA - Ministério do Desenvolvimento Agrário

MDIC - Ministério da Indústria, Comércio Exterior e Serviços

MDS - Ministério do Desenvolvimento Social

MDSA - Ministério do Desenvolvimento Social e Agrário

MEC - Ministério da Educação

MIE - Matriz de Identificação Estratégica

MR - Monitor Regional

MST - Movimento dos Trabalhadores Rurais Sem Terra

NOC - Núcleo operacional central

OEAFs - Organizações Econômicas da Agricultura Familiar

ONU - Organização das Nações Unidas

PAA - Programa de Aquisição de Alimentos

PAR - Ponto de Apoio Regional

PEIEx - Projeto de Extensão Industrial Exportadora

PGPAF - Programa de Garantia de Preço da Agricultura Familiar

PGPMBio - Política de Garantia de Preço Mínimo para os Produtos da Sociobiodiversidade

PLANSAN - Programa Nacional de Segurança Alimentar e Nutricional

PLO - Projeto de Lei Orçamentária

PMG - Programa Mais Gestão

PNAE - Programa Nacional de Alimentação Escolar

PNATER - Política Nacional de Assistência Técnica e Extensão Rural

PNHR - Política Nacional de Habitação Rural

PNPB - Programa Nacional de Produção e Uso do Biodiesel 
PRONAF - Programa Nacional de Fortalecimento da Agricultura Familiar

Pronat - Programa Nacional de Desenvolvimento Sustentável de Territórios Rurais

Pronater - Programa Nacional de Assistência Técnica e Extensão Rural

SAF - Secretaria de Agricultura Familiar

SDT - Secretaria de Desenvolvimento Territorial

Sead - Secretaria Especial de Agricultura Familiar e Desenvolvimento Agrário

SEAF - Seguro da Agricultura Familiar

Sipaf - Selo de Identificação de Participação da Agricultura Familiar

SRA - Secretaria de Reordenamento Agrário

TCU - Tribunal de Contas da União

TED - Termo de Execução Descentralizada

UFRB - Universidade Federal do Recôncavo Baiano

UFV - Universidade Federal de Viçosa 


\section{SUMÁRIO}

1. INTRODUÇÃO ___ 16

Justificativa ___ 20

Objetivo Geral ___ 22

Objetivos específicos ___ 22

Hipótese ___ 22

Procedimentos metodológicos ___ 22

2. POLÍTICAS PÚbliCAS, DESCONTINUIDADE E AS POLÍTICAS PÚBLICAS DE $3^{\text {a }}$ GERAÇÃO _ 26

Introdução____ 26

Políticas públicas ___ 28

O ciclo de políticas públicas____ 31

Identificação do problema ___ 32

Agenda ___ 33

Formulação de alternativas____ 34

Tomada de decisão ___ 34

Implementação ___ 34

Avaliação _ـ_ 35

A descontinuidade ___ 36

Fluxos múltiplos ___ 37

Problemas___ 38

Ambiente político ___ 39

Soluções _ 40

Conexão e janelas_______ 41

As Políticas Públicas de $3^{\text {a Geração ___ }} 42$

Programa de Aquisição de Alimentos - PAA ___ 49

Programa Nacional de Alimentação Escolar - PNAE __ 54

Programa Nacional de Produção e Uso do Biodiesel - PNPB

Breves considerações ___ 62

3. O PROGRAMA MAIS GESTÃo E O CICLO DE POLÍticAS PÚBliCAS _

Introdução___ 63

O Programa Mais Gestão ___ 64

Problema __ 66

Agenda __ 70

Formulação de alternativas____ 71

Tomada de decisão____ 74 
Implementação 75

As cooperativas do Programa Mais Gestão 81

Monitoramento e avaliação

Breves considerações 90

4. A DESCONTINUIDADE DO PROGRAMA MAIS GESTÃO E SEUS CONDICIONANTES 91

Introdução 91

A descontinuidade do Programa Mais Gestão 92

Fluxo de problemas 95

Fluxo de soluções 96

Fluxo político 96

A descontinuidade e um considerável valor investido 98

Breves considerações 100

5. CONSIDERAÇÕES FINAIS 101 REFERÊNCIAS 104 


\section{INTRODUÇÃO}

A criação de políticas públicas para a agricultura familiar ganhou destaque principalmente após a promulgação da Constituição Federal (CF), no ano de 1988. O histórico de tais políticas é marcado por lutas, desafios e conquistas para um segmento, até então alijado dos programas criados pelo Estado.

Desde o Programa Nacional de Fortalecimento da Agricultura Familiar (PRONAF) em 1995, passando pela criação de um ministério específico no ano 2000, o Ministério do Desenvolvimento Agrário (MDA) ${ }^{1}$, muito se acumulou para reforçar a categoria e sensibilizar a sociedade política e civil para sua importância.

As políticas concebidas aos agricultores familiares entre os anos 1990 e 2010 em sua grande maioria possuem inicialmente orientação ao crédito e à produção, salvo aquela de arranjos para a organização social e territorial destes grupos encampadas pela Secretaria de Desenvolvimento Territorial (SDT). Um segundo grupo de políticas se orientou para o problema da comercialização, tema amplamente diagnosticado por diferentes estudos nos anos 2000, como exposto nos estudos de Grisa (2012) ao analisar as políticas públicas para a agricultura familiar no Brasil, e a construção das três gerações de políticas públicas para a agricultura por Grisa e Schneider (2015b).

No período mais recente, o extinto MDA, por meio de políticas e programas voltados para a agregação de valor e geração de renda, vinha incentivando a agricultura familiar a organizar sua base produtiva e melhorar a gestão de seus empreendimentos coletivos, visando sua inserção qualificada nos mercados institucionais e privados. Essas políticas se traduziam em medidas concretas capazes de responder às especificidades da agricultura familiar, privilegiando a formulação de instrumentos de coordenação entre os elos da cadeia produtiva de modo a propiciar o aumento da competitividade dos produtos no mercado.

Nos mercados privados, os produtos da agricultura familiar gradativamente acumulam reconhecimento como resultado de acordos firmados entre o Ministério e redes nacionais e regionais de supermercados, com o objetivo de ampliar a oferta dos produtos

\footnotetext{
${ }^{1}$ A Medida Provisória $n^{\circ}$ 726, de 12 de maio de 2012 extinguiu o MDA e o Decreto $n^{\circ} 8.780$, de 27 de maio de 2016, transferiu as competências do referido ministério para a Secretaria Especial de Agricultura Familiar e do Desenvolvimento Agrário - Casa Civil da Presidência da República.
} 
da agricultura familiar, povos e comunidades tradicionais, neste segmento. Estes produtos, que ostentam o Selo de Identificação de Participação da Agricultura Familiar (Sipaf) em suas embalagens, divulgam e valorizam o trabalho das famílias do campo e da agricultura familiar como um todo, fortalecendo a identidade social da agricultura familiar perante os consumidores e divulgando a presença da agricultura familiar no mercado (BRASIL, 2014a).

Concomitante a este fenômeno, o Brasil vinha ganhando amplo reconhecimento internacional devido suas práticas para a erradicação da fome e a diminuição da pobreza e das desigualdades sociais. As ações coordenadas entre o Ministério do Desenvolvimento Social (MDS), o Ministério da Educação (MEC), o Fundo Nacional de Desenvolvimento da Educação (FNDE), o MDA e outros órgãos geraram um acúmulo de políticas e modos de fazer política que hoje são referências internacionais valorizadas por organismos internacionais, governos e instituições de pesquisa, conforme apontado nos estudos de Campos e Bianchini (2014) e também por Grisa e Schneider (2015a). Corroborando com esses autores, Sabourin (2017) ressalta que vários países, em particular da América Latina, têm buscado estabelecer acordos de cooperação e intercâmbios, com o intuído de identificar e realizar transferências de políticas públicas.

As experiências do Programa de Aquisição de Alimentos (PAA) e Programa Nacional de Alimentação Escolar (PNAE), sem dúvida, são as mais importantes neste cenário e se mostravam como alicerces de novas empreitadas por parte do Executivo Federal. Demandavam, por sua vez, o desenho de novas políticas para a manutenção do sucesso do PAA e PNAE e isso passava pela reorganização social e produtiva dos agricultores familiares e fortalecimento de arranjos produtivos locais.

Como resposta a esta demanda, surgiu o Programa Mais Gestão (PMG) criado no ano de 2012 pela Secretaria de Agricultura Familiar (SAF), do Ministério do Desenvolvimento Agrário. O Programa tinha como objetivo promover o acesso das cooperativas da agricultura familiar aos mercados institucionais: PAA, PNAE e PNPB (Programa Nacional de Produção e Uso do Biodiesel), por meio do aperfeiçoamento da gestão de tais organizações.

O PMG foi construído como estratégia de assistência técnica orientada para a gestão e comercialização de grupos de produtores familiares organizados em cooperativas e associações e procurava criar planos estratégicos para a qualificação e manutenção destes grupos nos mercados institucionais. 
Geralmente, as políticas públicas de reforma agrária e de agricultura familiar são resultados de conquistas sociais acumuladas, a partir de construções e conflitos sociais (SABOURIN, 2014). Como são inúmeros os atores, organismos e contexto político envolvidos durante a formulação de políticas públicas, a compreensão de como ocorreu essa trajetória torna-se fundamental.

Entre as décadas de 1960 e 70, o Brasil adotou instrumentos com o intuito de potencializar a produção agrícola, por meio de crédito rural, garantia de preço, Assistência Técnica e Extensão Rural (ATER) e pesquisas (GRISA, 2012). A democratização no Brasil permitiu que os atores sociais pudessem articular-se para clamar a criação de políticas públicas para classes até então aquém dos interesses governamentais. É importante destacar a criação da Central Única dos Trabalhadores (CUT) em 1983; a conformação do Departamento Nacional de Trabalhadores Rurais (DNTR) em 1988; a constituição do Movimento dos Trabalhadores sem Terra (MST) em 1984; a institucionalização do Movimento dos Atingidos por Barragens (MAB) em 1991 e a criação do Conselho Nacional dos Seringueiros (CNS) em 1985 (GRISA, 2012).

Com relação à governabilidade do País, durante o governo do ex-presidente Fernando Henrique Cardoso, o Brasil provocou a criação de 9.000 projetos de assentamentos, entre 1995 e 2002 (SANTOS NETO, 2016). A partir de 2003, com o início do governo petista, presidido pelo ex presidente Luiz Inácio Lula da Silva, foram criadas diversas políticas com foco ao desenvolvimento dos agricultores familiares, como PAA, PNAE, PNATER e outras.

Mesmo frente à importância da agricultura familiar para o país, conforme dados do Censo Agropecuário de 2006 (BRASIL, 2006b), os estabelecimentos da agricultura familiar representam 84, 36\% de um total de 5.175.636, ocupando apenas 24,01\% da área total. Mesmo com uma área consideravelmente menor, a agricultura familiar é responsável pela seguinte produção: 
Tabela 1 - Produção da agricultura familiar de produtos selecionados no ano de 2006

\begin{tabular}{|c|c|}
\hline Produto & Produção da agricultura familiar \\
\hline Arroz em casca $(1.000 \mathrm{t})$ & 3.204 \\
\hline Feijão-preto $(1.000 \mathrm{t})$ & 512 \\
\hline Feijão de cor $(1.000 \mathrm{t})$ & 685 \\
\hline $\begin{array}{l}\text { Feijão-outros (Feijão-fradinho, caupi, de corda ou } \\
\text { macácar, em grão) (1.000 t) }\end{array}$ & 953 \\
\hline Feijão-total (1.000 t) & 2.149 \\
\hline Mandioca $(1.000 \mathrm{t})$ & 9.907 \\
\hline Milho em grão (1.000 t) & 18.873 \\
\hline Soja $(1.000 \mathrm{t})$ & 6.465 \\
\hline Trigo $(1.000 \mathrm{t})$ & 473 \\
\hline Café em grão (verde) (1.000 t) & 919 \\
\hline Leite de vaca ( $10^{6}$ litros $)$ & 11.849 \\
\hline Leite de cabra ( $10^{6}$ litros $)$ & 24 \\
\hline Ovos de galinha ( $10^{6}$ dúzias) & 451 \\
\hline
\end{tabular}

Fonte: Censo Agropecuário (2006b)

Apesar do claro reconhecimento e incremento apresentado, as políticas destinadas à agricultura familiar sempre estiveram vulneráveis aos ataques e tentativas de desqualificação oriundas de "parcelas" da sociedade ligadas: ao agronegócio, aos movimentos patronais da agricultura, aos latifundiários, grileiros, parlamentares da bancada ruralista e do próprio Ministério da Agricultura Pecuária e Abastecimento (MAPA). Parte desses esforços já alcançavam sucesso nos governos Lula-Dilma inviabilizando estratégias, sobretudo as mais críticas como aquelas pautas ligadas à reforma agrária e ao uso de agrotóxicos e também na disputa interna do governo por recursos financeiros.

Porém, mais recentemente, com a crise institucional e econômica que deu início com o processo de destituição da presidenta Dilma, a partir do ato de aceite de abertura do processo de impeachment pelo ex-presidente da Câmara dos Deputados, Eduardo Cunha. Os novos atores que encabeçavam a agenda política, liderados pelo presidente interino Michel Temer, iniciam um quadro de desmonte de políticas que merece o aprofundamento analítico e a sua reflexão.

O objetivo do presente estudo, portanto, enquadra-se, no campo das políticas públicas para as cooperativas de agricultura familiar e a descontinuidade dos programas para esse público. Desse modo, apresenta-se a questão orientativa do estudo: Quais 
fatores propiciam a decontinuidade de uma política pública? Para responder a essa questão, foi realizado um estudo sobre o PMG e usado o referencial analítico dos fluxos múltiplos (KINGDON, 2006a) que procura explicar a concepção das políticas públicas a partir de três fluxos (problemas, soluções e político). O destaque aqui apresentado é a utilização deste referencial para explicar a descontinuidade de políticas públicas. Para subsidiar a compreensão e na tentativa de responder à questão, essa dissertação busca apontar as ideias, a dinâmica do Programa e sua execução, por meio da elucidação do ciclo de políticas públicas aplicado ao PMG.

\section{$\underline{\text { Justificativa }}$}

O conteúdo da produção acadêmica voltada para políticas públicas tem sido, em boa medida, a avaliação dos resultados alcançados pelas políticas, ou a atualização da informação existente sobre programas já consolidados (AVILA; CALDAS; ASSAD, 2013; GRISA; WESZ JUNIOR; BUCHWEITZ, 2014; PORTO, 2014; SANTOS NETO, 2016; SOUSA, 2015). Na verdade, a subordinação da agenda de pesquisa à agenda política é potencialmente maior na área de políticas públicas do que em outras áreas do conhecimento (TREVISAN; BELLEN, 2008).

Embora sejam volumosos os estudos voltados as temáticas centrais desta dissertação, em particular as discussões sobre análise de políticas públicas, como o estudo de Bonduki (2017) sobre o PNAE e o desenvolvido por Grisa a respeito do PAA (2010), além de pesquisas sobre a agricultura familiar (BONDUKI, 2017; DELGADO; BERGAMASCO, 2017; FORNAZIER; BELIK, 2011) existem certas lacunas em relação a descontinuidade de políticas públicas (SPINK, 1987; SPINK; CLEMENTE; KEPPKE, 1997). Em particular, o presente estudo difere-se dos voltados à descontinuidade de políticas públicas, pois, esse propõe-se a compreender e analisar a descontinuidade de um programa governamental ancorado na teoria de fluxo múltiplos.

No tocante a extinção e descontinuidade, foi somente na década de 1970 que os estudos sobre a extinção de políticas públicas tiveram atenção dos acadêmicos (SOUZA; SECCHI, 2015, p. 76). Como apontado por Estevam ([s.d.]), mesmo com a modernização do setor público, a descontinuidade das políticas públicas não têm diminuído. Conforme Souza e Secchi (2015), um dos motivos para a extinção de políticas públicas é a mudança na administração e no governo. Nesse sentido, a cada mudança governamental a dúvida sobre a continuidade ou não de programas paira sobre os executores das políticas e 
também sobre a sociedade. Um dos motivos apontados por DeLeon (1982) para explicar a rescisão de políticas públicas é a necessidade de cortes governamentais, demissões e reduções gerais, relacionada principalmente aos orçamentos públicos. Assim, é importante compreender qual (is) fator (es) foi (ram) fundamental (is) para a proposta e efetiva descontinuidade de uma política pública.

Em casos em que um problema que tenha originado certa política pública seja sanado, a decisão mais acertada é extinguir a política ou programa. No entanto, a extinção diversas vezes é difícil de ser concretizada. Tal dificuldade é justificada pela imagem que o ator responsável por extinguir a política passa a ter (BARDACH, 1976; DELEON, 1982; GUTIÉRREZ, 2016).

De modo geral, os estudos acerca das políticas públicas e programas tendem a compreender e analisar sua formação, avaliar sua implementação e entender seus determinantes. Isso pode ser explicado pela relevância que os autores dão às novas políticas em detrimento a sua extinção (SOUZA; SECCHI, 2015).

Esse trabalho foi desenrolado após indagações levantadas por Souza e Secchi em 2015, no estudo Extinção de políticas públicas: síntese teórica sobre a fase esquecida do policy cicle. No artigo citado, os autores apontam a "pouca preocupação" sobre a extinção de política pública e também lacunas sobre tal fase do ciclo de políticas públicas. Diante disso, ao final do estudo os autores questionam a possibilidade de utilizar o modelo de fluxos múltiplos de Kingdon para a análise de extinção de políticas públicas, método sugerido também por Cabral no texto As mudanças na agenda das políticas públicas para a agricultura familiar promovidas pelo governo Michel Temer (2017).

Dessa maneira, a presente dissertação buscou apresentar os fluxos políticos, de problemas e de soluções que propiciaram a extinção do Programa Mais Gestão, integrando a análise dos textos pertinentes e possíveis considerações, possibilitando a compreensão dessa decisão repentina. Portanto, justifica-se realizar tal estudo em face da pergunta central que dialoga com a necessidade de investigar quais foram os fatores que provocaram a descontinuidade do Programa Mais Gestão, sem um processo de avaliação consolidado.

O estudo propõe ainda apresentar, ao longo do texto, características das cooperativas que foram atendidas pelo referido Programa, o que poderá auxiliar em uma 
melhor construção das políticas públicas futuras a serem elaboradas pelo governo, ou mesmo avaliação de programas já lançados.

Considerando que a dissertação busca convergir os assuntos e elaborar uma análise teórica coerente ao que se propõe, os objetivos propostos para o estudo são:

\section{Objetivo Geral}

Compreender os fatores que levaram a descontinuidade do Programa Mais Gestão utilizando as abordagens do ciclo de políticas públicas e dos fluxos múltiplos.

\section{Objetivos específicos}

(1) Analisar as principais políticas públicas de apoio acessadas pelas cooperativas de agricultura familiar atendidas pelo Programa Mais Gestão.

(2) Realizar uma análise do Programa Mais Gestão desde sua concepção até sua avaliação, por meio do ciclo de políticas públicas.

(3) Evidenciar as principais características das cooperativas atendidas pelo Programa Mais Gestão.

(4) Analisar os determinantes que promoveram a descontinuidade do Programa Mais Gestão, por meio dos fluxos múltiplos.

\section{Hipótese}

A hipótese desta dissertação é de que a descontinuidade do Programa Mais Gestão foi dada após a mudança no fluxo político.

\section{$\underline{\text { Procedimentos metodológicos }}$}

Com vistas ao cumprimento dos objetivos propostos para o presente estudo, considera-se pertinente a utilização de técnicas qualitativas (pesquisa documental e revisão bibliográfica). Conforme Creswell (2007), a investigação qualitativa é fundamentalmente interpretativa, incluindo a descrição, análise e possivelmente conclusões sobre determinado estudo. $\mathrm{O}$ autor aponta ainda que o pesquisador vê os fenômenos sociais holisticamente, quanto mais complexa, interativa e abrangente a narrativa melhor o estudo.

Quanto ao que se propõe para o estudo apresentado, este pode ser classificado como uma pesquisa aplicada, por se ater menos ao desenvolvimento de teorias, mas, por outro 
lado, a utilização e consequências práticas dos conhecimentos, ao desenvolver um referencial teórico de políticas públicas para a agricultura familiar, conforme capítulo 3 (GIL, 2008).

Por descrever características das cooperativas que foram atendidas pelo Programa Mais Gestão, a dissertação pode ser classificada como uma pesquisa descritiva. Os procedimentos metodológicos da dissertação estão caracterizados também como uma pesquisa exploratória, que se atém em levantamento bibliográfico e documental, além do uso de entrevistas não padronizadas (GIL, 2008).

A primeira etapa do trabalho foi direcionada à interpretação e triangulação dos dados secundários oriundos de pesquisa documental e bibliográfica, que possibilitou a construção do referencial teórico e revisão bibliográfica dos conceitos trabalhados na dissertação: políticas públicas e agricultura familiar. Dentre as principais fontes para construção de breve histórico das principais políticas públicas que as cooperativas do Programa Mais Gestão acessavam (PAA, PNAE e PNPB) destacam-se as de cunho normativo (leis, decretos, instruções normativas e chamadas públicas), além de livros, teses e artigos que também pautaram sobre o tema proposto.

Após compreensão do referencial teórico orientador para o presente estudo, foi possível construir o ciclo de vida do PMG e também evidenciar os fluxos que orientaram a descontinuidade do mesmo. Para realização dessas etapas que estão atreladas aos capítulos 4 e 5 , foram utilizadas as seguintes fontes:

(1) Chamadas públicas $n^{\circ} 04 / 2012, n^{\circ} 06 / 2012, n^{\circ} 07 / 2012$ e n 17/2013 para contratação das equipes de ATER com vistas à execução do Programa Mais Gestão;

(2) Documentos elaborados pela "Rede de Universidades na Avaliação do Programa Mais Gestão" 2, contratada pelo Termo de Execução Descentralizada (TED) $\mathrm{n}^{\circ}$ 046/2014, celebrado pelo Ministério do

\footnotetext{
2 Agradecimentos ao estudo realizado e disponibilização de dados, no âmbito do Projeto "Rede de Universidades na Avaliação do Programa Mais Gestão", financiado pelo MDA, em colaboração com a Rede de Cooperação em Pesquisa da Agricultura Familiar (Rede Mais Gestão). Com a participação das seguintes instituições de ensino: Universidade Federal de Viçosa, Universidade de Brasília, Universidade do Recôncavo Baiano, Universidade Federal do Rio Grande do Sul, Universidade Federal Rural de Pernambuco.
} 
Desenvolvimento Agrário (MDA) e a Universidade Federal de Viçosa (UFV);

(3) Entrevistas não estruturadas realizadas com pessoas envolvidas na construção do Programa, gestores do Ministério do Desenvolvimento Agrário (MDA), técnicos das equipes de ATER contratadas, diretores das cooperativas e representantes, realizadas em parceria com a Rede de Universidades na Avaliação do Programa Mais Gestão ${ }^{3}$.

A partir de tais fontes, foi possível, portanto, realizar esta pesquisa com base na seguinte dinâmica:

Figura 1 - Dinâmica metodológica e instrumentos de pesquisa.

\section{ETAPAS}

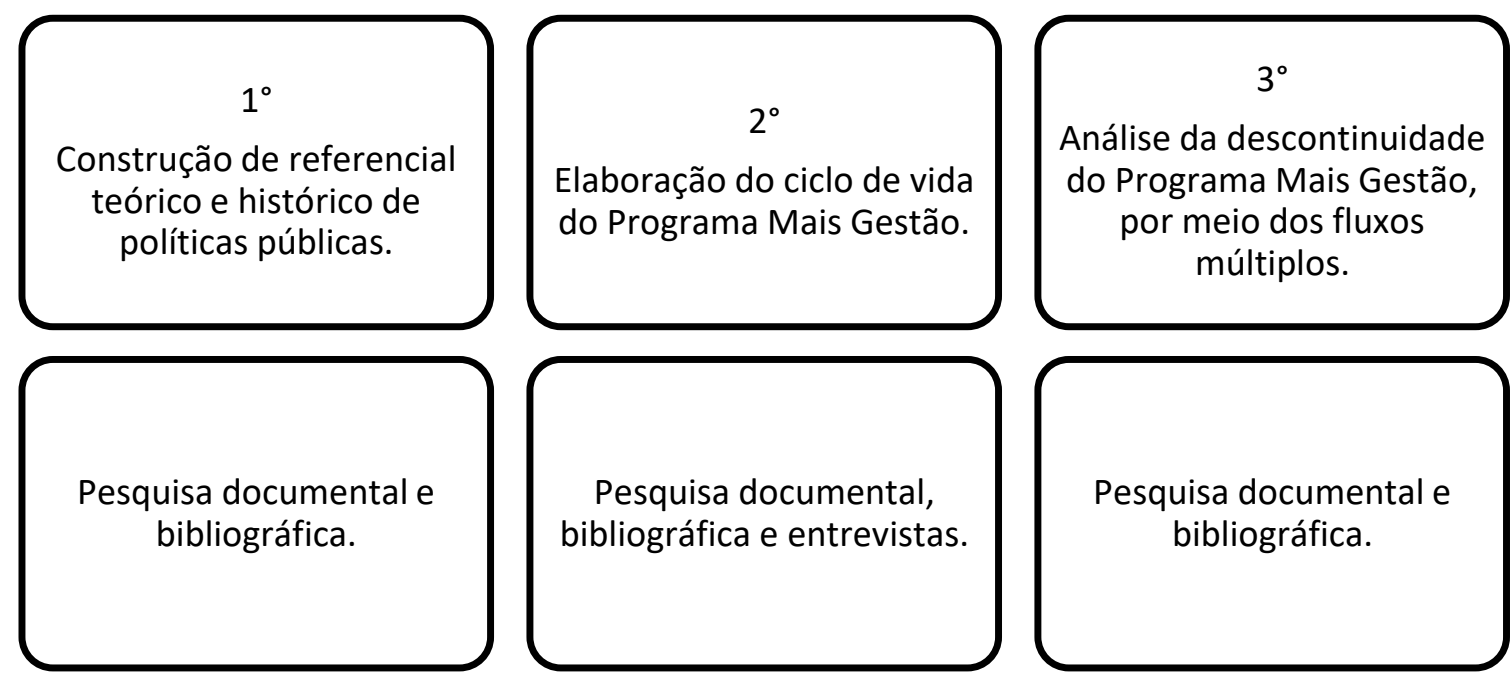

Porém, para garantir a veracidade dos dados apresentados, foram utilizadas diversas fontes e os dados das cooperativas foram obtidos diretamente do MDA, por meio da Rede de Universidades na Avaliação do Programa Mais Gestão.

Diante do exposto, a estrutura da dissertação está organizada em cinco capítulos, incluindo a introdução e a conclusão. No capítulo 2 é realizada uma revisão de literatura sobre políticas públicas, descontinuidade e as políticas públicas de $3^{\text {a }}$ geração para a agricultura familiar, com enfoque ao PAA, PNAE e PNPB, visto que são os mercados institucionais de que trata o Programa Mais Gestão. O objetivo é revisitar as principais explicações do ciclo de políticas públicas e dos fluxos múltiplos, além de um breve estudo

\footnotetext{
${ }^{3}$ Os nomes dos atores entrevistados não foram divulgados, com vistas a garantir a privacidade dos mesmos.
} 
dessas políticas públicas de $3^{\mathrm{a}}$ geração. No capítulo 3 , é apresentado o histórico e as características do Programa Mais Gestão, os agentes que propiciaram sua concepção, condicionantes e evolução, à luz do ciclo de políticas públicas. No capítulo 4, a partir do levantamento teórico, histórico dos programas e dos dados quantitativos, é analisada a descontinuidade do Programa Mais Gestão e suas possíveis causas. 


\section{POLÍTICAS PÚBLICAS, DESCONTINUIDADE E AS POLÍTICAS

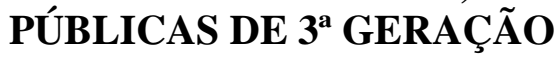

\section{Introdução}

A pesquisa buscou localizar este estudo no universo das questões relativas a políticas públicas. As questões específicas estão diretamente relacionadas a descontinuidade de políticas públicas ou "extinção de políticas públicas", conforme exposto por Souza e Secchi (2015), a partir da ideia de fluxos múltiplos.

Por meio deste recorte buscou-se apresentar a compreensão de políticas públicas, ancorada em duas linhas de estudo: o ciclo de políticas públicas (policy cicle) (SECCHI, 2010) e o modelo dos fluxos múltiplos (KINGDON, 2006a). Assim, foi possível compreender a formulação de políticas públicas e reconhecer os possíveis mecanismos que explicam a extinção. Pressupõe-se que as duas teorias são complementares uma à outra, para contribuir com o conjunto explicativo do fenômeno de extinção de uma política pública.

Posteriormente, por meio desse recorte serão apresentadas e discutidas as políticas públicas de fomento acessadas pelas cooperativas do Programa Mais Gestão e também a compreensão das fases do referido programa. A justificativa para a escolha dessas teorias deve-se ao fato de buscar compreender a extinção de uma política por meio das mesmas teorias que permitem fundamentar sua gênese.

Desta maneira, neste capítulo objetiva-se compreender as políticas públicas, ancorado nas definições para esse conceito ao longo dos anos, por meio de um arcabouço teórico que apresenta as teorias do ciclo de políticas públicas e dos fluxos múltiplos e desenvolver ainda uma breve síntese dos programas PAA, PNAE e PNPB.

Este capítulo está estruturado, além desta introdução e de breves considerações, nos seguintes pontos:

(1) Políticas públicas, com o objetivo de compreender as principais conceituações sobre o termo;

(2) O ciclo de políticas públicas, com o intuito de apresentar cada fase do ciclo das políticas públicas;

(3) Fluxos múltiplos. Tal seção tem a pretensão de situar a teoria dos fluxos múltiplos a partir dos estudos de Kingdon (KINGDON, 2006a). 
(4) Políticas públicas de $3^{\circ}$ geração. Tem o objetivo de apresentar a teoria das gerações de políticas públicas e os programas acessados pelas cooperativas atendidas pelo Programa Mais Gestão. 


\section{Políticas públicas}

Os agricultores familiares construíram históricos de lutas para que políticas públicas fossem criadas para a categoria. Para realizar um estudo acerca das políticas públicas para agricultura familiar, é fundamental, porém, compreender a princípio o que significa uma política pública, a quem se destina e para que elas servem. A compreensão sobre o que é uma política pública foi sendo modificada e qualificada, sendo possível observá-la por diversos olhares.

A origem dos estudos na área de políticas públicas surge na Europa a partir do desdobramento dos trabalhos que buscam explicar o papel do Estado e do governo. Por outro lado, nos Estados Unidos tal área de estudos é oriunda do mundo acadêmico, com ênfase sobre a ação dos governos (SOUZA, 2006). A visibilidade da área, ainda de acordo com Souza (2006, p. 20), perpassa por alguns fatores. Em primeiro lugar, tal visibilidade está associada às políticas restritivas de gasto, que dominaram a agenda de inúmeros países. Em segundo lugar, "novas visões sobre o papel dos governos substituíram as políticas keynesianas ${ }^{4}$ do pós-guerra por políticas restritivas de gasto”. Em terceiro lugar e associado aos países em desenvolvimento, de democracia recente ou recémdemocratizados, a evidência desta área esteve aliada à falta de coalizões políticas responsáveis por impulsionar o desenvolvimento econômico e a inclusão social, por meio de políticas públicas.

Os estudos acerca das políticas públicas estão associados às policy sciences, uma ciência social que busca "a produção de conhecimento direcionado à resolução de problemas governamentais por meio da expertise de técnicos treinados em métodos de análise e solução de problemas" (CAPELLA, 2015, p. 241). Tal movimento fomentou os debates voltados para a produção de políticas públicas. Assim, a partir dos anos 1960, "diversos esforços foram conduzidos no sentido do desenvolvimento de técnicas e métodos para a análise de políticas públicas, aplicando conhecimentos oriundos da engenharia, pesquisa em operações, matemática aplicada e economia" (CAPELLA, 2015, p. 242).

\footnotetext{
${ }^{4}$ O keynesianismo é uma doutrina ativista, que preconiza a ação do Estado na promoção e sustentação do pleno emprego em economias empresariais. A teoria keynesiana, em parte como herança do seu próprio criador, tem como objeto o mundo real, de modo a ter bem claro que a construção de conceitos e modelos não é, de modo algum, um fim em si mesmo, mas um instrumento de pesquisa empírica e derivação de políticas de ação (CARVALHO, 2008).
} 
Com foco nas ações políticas, Rua ([s.d.], p. 1) aponta que "as políticas públicas (policies) são outputs, resultantes das atividades políticas (politics) que compreendem o conjunto das decisões e ações relativas à alocação imperativa de valores”. É importante distinguir política pública e decisão política, a primeira envolve mais que uma decisão e necessita de ações para que as decisões sejam implementadas. A segunda, por outro lado, relaciona-se a uma escolha dentre diversas alternativas (RUA, [s.d.], p. 1). Convém ressaltar o caráter "público" das políticas públicas, que refletem um caráter "imperativo", ou seja, as ações e decisões estão revestidas da autoridade soberana do poder público (RUA, [s.d.], p. 2).

Corroborando com os ideais apontados por Rua ([s.d.]), Souza (2006) em seu estudo sobre políticas públicas evidencia alguns conceitos orientadores sobre o termo e que condizem com as atividades do governo. Desse modo: para Lynn (1980) as políticas públicas são um conjunto de ações do governo produzindo efeitos específicos. Para Peters (1986) é a soma de atividades do governo que influenciam a vida da sociedade, enquanto Dye (1984) define como "o que o governo escolhe fazer ou não fazer" (apud SOUZA, 2006, p. 24). A autora ressalta ainda que as políticas públicas representam o campo de conhecimento que busca tanto manter o governo em atividade e/ou analisar essa ação, e ainda, quando necessário, indicar mudanças para tais ações (SOUZA, 2006).

Em reforço aos autores supracitados, Molina (2012) apresenta a definição de Gobert e Muller sobre essa expressão. Para eles, políticas públicas significam o Estado em ação (1987, apud 2012, p. 588). Segundo a autora, tais políticas traduzem as ações do Estado na forma de programas que visam materializar os direitos constitucionais (MOLINA, 2012, p. 588).

Capella (2015) apresenta a política pública como uma solução para um problema governamental. De acordo com a autora, a análise de uma política tem como intenção a eficiência, "com base na identificação do curso de ação mais eficiente possível para um dado problema percebido" (CAPELLA, 2015, p. 243). Um aspecto a ser considerado nessa definição é a ambiguidade e indefinição dos objetivos de uma política, revelando que pode haver uma distância significativa entre o que está definido e o que é realizado.

Ainda convergindo com a linha de pensamentos de uma política pública como algo atrelado a ação governamental, Souza e Secchi (2015, p. 77) apontam que uma política pública "é uma entidade abstrata, que se materializa por instrumentos concretos, tais 
como programas, projetos, obras, organizações, campanhas e leis nas diversas áreas de atuação pública".

É perceptível, portanto, que embora existam inúmeros conceitos para esse termo, todos convergem para alguns pontos, refletindo em particular as atitudes do governo que contemplam de maneira positiva ou negativa a tentativa de atingir determinados objetivos. Os programas, portanto, são vistos como um recurso para a implementação das políticas públicas. Convém ressaltar que a articulação dos programas é compreendida muito mais como uma ação das próprias políticas, do que dos processos de planejamento e coordenação (AVILA; CALDAS; ASSAD, 2013).

Embora não destoante das teorias que convergem para a ação governamental, Saravia (2006, p. 28) aponta que política pública "trata-se de um fluxo de decisões públicas, orientado a manter o equilíbrio social ou a introduzir desequilíbrios destinados a modificar essa realidade".

Diante das definições apresentadas, é importante ressaltar, como conceito orientador para o desenvolvimento do presente estudo, a noção apresentada por Secchi (2010), segundo o qual as políticas públicas são diretrizes elaboradas para enfrentar um problema público. É importante lembrar ainda que a política pública pode ser uma

orientação à atividade ou à passividade de alguém; as atividades ou passividades decorrentes dessa orientação também fazem parte da política pública; uma política pública possui dois elementos fundamentais: intencionalidade pública e resposta a um problema público (SECCHI, 2010, p. 2).

O problema público, que orienta a elaboração e definição de uma política pública, é compreendido como a diferença entre aquilo que se tem como realidade e uma situação ideal possível para a realidade (SECCHI, 2010). Além disso, para ser considerado público, o problema deve abarcar ou mesmo gerar implicações para uma considerável quantidade de pessoas.

Uma linha de estudo apresentada por Secchi e que é base para o desenvolvimento desta dissertação é a abordagem multicêntrica, segundo a qual, o que dá a característica pública do termo políticas públicas é o caráter do problema, ou seja, são inúmeros os protagonistas na elaboração das políticas públicas: organizações privadas, organizações não governamentais, organismos multilaterais, redes de políticas públicas e sociedade civil em geral. A abordagem multicêntrica, aqui considerada, vai em desacordo à abordagem estatista, que considera que o que torna as políticas públicas como pública de 
fato, são os responsáveis pela sua criação. Dessa forma, na abordagem estatista a elaboração está no monopólio dos atores estatais (SECCHI, 2010). Compreende-se, portanto, que a política aqui apresentada está relacionada a um problema público, que abarca e gera implicações a diversos atores.

Além dos problemas públicos, as políticas públicas podem surgir ainda por meio das demandas, sejam elas novas ou recorrentes. As demandas novas são identificadas como aquelas que advém de novos atores políticos ou novos problemas. Por outro lado, as demandas recorrentes são caracterizadas como problemas não resolvidos, ou mesmo, mal resolvidos (RUA, [s.d.]).

A análise dessas políticas pode ser realizada de algumas formas, seja ela por um setor específico da qual faz parte, como por exemplo, a educação, ou mesmo a partir do seu ciclo. A partir disso, a presente dissertação está orientada por duas análises: o ciclo de políticas públicas (policy cycle) e o modelo dos fluxos múltiplos. Primeiramente, será observada a teoria do ciclo de políticas públicas, seguida da teoria dos fluxos múltiplos.

\section{O ciclo de políticas públicas}

Alguns estudos sobre políticas públicas têm proporcionado modelos explicativos do processo de decisão, elaboração, implementação e avaliação das ações governamentais. Nesse sentido, o ciclo das políticas públicas busca "explicar a interação entre intenções e ações, ao mesmo tempo em que busca desvendar a relação entre o ambiente social, político e econômico, de um lado, e o governo, de outro" (PINTO, 2008, p. 28).

O ciclo de políticas ou processo de elaboração de políticas públicas (policy-making process) "é um esquema de visualização e interpretação que organiza a vida de uma política pública em fases sequenciais e interdependentes" (SECCHI, 2010, p. 33). Souza aponta que essa teoria compreende a política pública como "um ciclo deliberativo, formado por vários estágios e constituindo um processo dinâmico e de aprendizado" (SOUZA, 2006, p. 29).

Esse ciclo compreende sete fases, conforme delineado na Figura 2. A política pública tem início com a identificação do problema, seguido da formação da agenda. Com uma agenda favorável são criadas alternativas para posterior implementação. Implementada a política, esta é avaliada e caso necessário, ela é por fim extinta. 
Figura 2 - O ciclo de políticas públicas e suas sete fases.

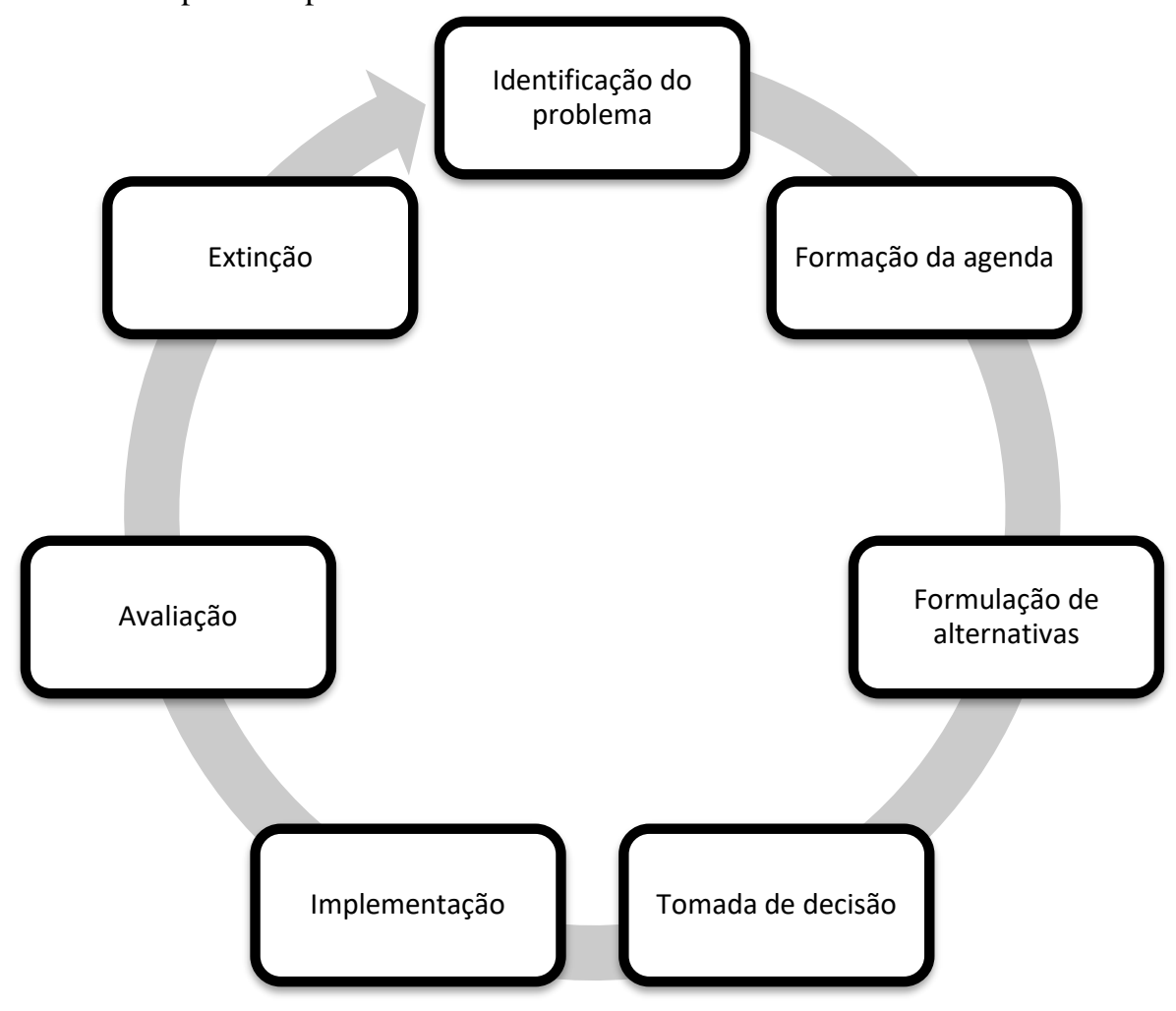

Fonte: Secchi (2010, p. 33).

É importante compreender que apesar de sua utilidade para estudos e análises, raramente o ciclo de políticas públicas reflete a real dinâmica de uma política (GUTIÉRREZ, 2016). O ciclo, portanto, auxilia na organização das ideias, simplifica o processo e auxilia os políticos, governantes e pesquisadores a criar referenciais comparativos (SECCHI, 2010; TREVISAN; BELLEN, 2008).

Uma das questões centrais para essa análise é a formação da agenda (agenda setting), que busca compreender por que algumas demandas entram na agenda política e outras não. No ciclo, os participantes são fundamentais e podem atuar como incentivo ou ponto de veto (SOUZA, 2006). Desse modo, os atores, de maneira geral políticos, acadêmicos e representantes de movimentos sociais lutam por seus interesses.

\section{Identificação do problema}

Conforme citado acima, um problema é a diferença entre a realidade e uma situação ideal possível. Secchi (2010) aponta que os problemas públicos podem aparecer subitamente e ganhar importância pouco a pouco, ou mesmo existir há muito tempo, porém, sem receber a devida atenção da sociedade. A identificação de um problema por parte de um ator político e o interesse na resolução do referido problema, indicam que 
esse ator pode empenhar-se para que o problema faça parte da lista de prioridades do governo.

O sucesso no processo de formação de agenda depende da definição do problema, no quão os formuladores de política dão atenção a ele e ainda no quanto ele está articulado. Esse processo se torna altamente competitivo, em vista das inúmeras questões e problemas que circundam a agenda governamental (CAPELLA, 2015).

\section{Agenda}

A agenda é um conjunto de problemas ou temas entendidos como relevantes. Para tanto, "a agenda é definida como um conjunto de assuntos sobre os quais tanto o governo quanto as pessoas a ele ligadas gastam seu tempo e concentram sua atenção" (CALDAS, 2007, p. 40).

Durante a formação da agenda, é fundamental levar em consideração as causas que provocam a entrada de determinado problema na agenda. Nesse aspecto, é importante compreender as relações políticas e a influência dos atores envolvidos. "Assim, a teoria da formação de agenda preocupa-se em saber como o governo toma decisão sobre determinada política pública num ambiente político plural e sob a influência e a pressão de grupos diversos" (CALDAS, 2007, p. 18).

À pergunta sobre como os governos definem suas agendas, são dados três tipos de respostas.

- A primeira resposta focaliza os problemas, isto é, os problemas entram na agenda quando a sociedade como um todo dá a devida atenção a ele.

- A segunda resposta relaciona-se à política propriamente dita, ou seja, como se constrói a consciência coletiva (sociedade civil) para a resolução de determinado problema. A consciência coletiva, de acordo com essa resposta, é determinante para a definição da agenda. A construção pode ser realizada via processo eleitoral, mudanças nos partidos que governam ou via mudanças nas ideologias, atrelados à força ou à fraqueza dos grupos de interesse. É importante ressaltar, ainda, que o consenso é construído mais por "barganha do que por persuasão, ao passo que, quando o ponto de partida da política pública encontra-se no problema a ser enfrentado, dá-se o processo contrário, ou seja, a persuasão é a forma para a construção do consenso" (SOUZA, 2006, p. 30).

- Finalmente, a terceira resposta aponta os participantes como fundamentais para a definição da agenda. Segundo esse ponto, os participantes visíveis (políticos, 
mídia, partidos, grupos de pressão, etc.) são responsáveis por definir a agenda, enquanto os invisíveis (acadêmicos e burocracia), as alternativas.

\section{Formulação de alternativas}

Com relação à etapa de construção de alternativas, esse "é o momento em que são elaborados métodos, programas, estratégias ou ações que poderão alcançar os objetivos estabelecidos" (SECCHI, 2010, p. 37). As alternativas são as soluções, ou ideias, geradas para que se possa resolver determinada questão. Geralmente essas alternativas são geradas em comunidades de especialistas (policy communities) que são compostas por pesquisadores, acadêmicos, funcionários públicos, assessores parlamentares, analistas de grupos de interesses (CAPELLA, 2015).

\section{$\underline{\text { Tomada de decisão }}$}

O momento de tomada de decisão é aquele em que são levados em conta os interesses dos atores e as intenções para o enfrentamento de um problema público. São reconhecidas três formas para compreensão desse processo:

- Há um problema considerado relevante e com objetivos já definidos e o tomador de decisão parte em busca da melhor alternativa.

- Os problemas e as soluções são ajustados uns aos outros, ou seja, eles ocorrem simultaneamente.

- Existe uma solução já concebida e o tomador de decisão busca o problema para resolver, promovendo a solução em política pública.

\section{Implementação}

O processo de implementação é compreendido como "o conjunto de ações realizadas por grupos ou indivíduos de natureza pública ou privada" direcionadas para a consecução dos objetivos estabelecidos" por meio da tomada de decisão anterior (RUA, [s.d.], p. 13). A fase de implementação é "aquela em que a administração pública revestese de sua função precípua, a de transformar intenções políticas em ações concretas" (SECCHI, 2010, p. 46).

A implementação compreende que cada ação nesse processo é interdependente da outra, ou seja, para que a política pública seja implementada é necessária uma cooperação significativa entre os autores envolvidos. Desse modo, é fundamental observar as pessoas e organizações, os interesses, as competências, as relações entre os envolvidos, os recursos que subsidiam a implementação de fato (financeiros, materiais) e ainda a capacidade de influência política (SECCHI, 2010). 
São apresentados, portanto, dois modelos de implementação de política pública, o modelo top-down (de cima para baixo) e o modelo bottom-up (de baixo para cima). $\mathrm{O}$ modelo top-down é caracterizado por uma clara distinção entre a tomada de decisão e a implementação, ou seja, as decisões são tomadas pela esfera política enquanto a implementação ocorre por meio das ações dos agentes. Por outro lado, o modelo bottomup sugere uma considerável interação entre a rede de atores e a esfera política, permitindo maior discricionariedade para os gestores e os burocratas.

\section{$\underline{\text { Avaliação }}$}

O momento da avaliação deve ser compreendido como um mecanismo de melhoria. Nesse aspecto, a avaliação pode garantir melhores informações para fundamentar as decisões e realizar possíveis prestações de conta.

De acordo com Trevisan e Bellen (2008), caso os objetivos do programa tenham sido atendidos, a política pode ser suspensa ou mesmo chegar ao fim. Caso contrário, se os objetivos não tiverem sido atingidos e o problema solucionado, dá-se início a um novo ciclo.

O resultado das avaliações pode ser enxergado como um problema para os governantes, executores e gerentes de projetos, porque as informações podem causar possíveis constrangimentos públicos ou até mesmo serem utilizadas para criticar o governo. Por outro lado, caso a avaliação tenha um resultado positivo, os governos podem usá-la em benefício próprio, pela legitimação das próprias políticas (TREVISAN; BELLEN, 2008).

A avaliação pode indicar a continuação da política pública, sua reestruturação ou em alguns casos sua extinção. De maneira geral, os principais critérios para a avaliação de uma política são, segundo Secchi (2010):

(1) Economicidade: refere-se ao nível de utilização dos recursos;

(2) Eficiência econômica: relaciona os recursos utilizados e a produtividade;

(3) Eficiência administrativa: trata do nível de conformação da execução a métodos preestabelecidos;

(4) Eficácia: corresponde ao nível de alcance de metas ou objetivos preestabelecidos; 
(5) Equidade: trata da homogeneidade de distribuição dos benefícios ou punições dos destinatários da política.

\section{$\underline{\text { A descontinuidade }}$}

A definição de continuidade ou descontinuidade de um programa é relativamente simples: se continua existindo ou não, se foi mantido ou não (SPINK; CLEMENTE; KEPPKE, 1997). Esse processo reflete grande amplitude, que envolve a questão do Estado, mas também a realidade vivenciada por inúmeros funcionários públicos, principalmente em momentos de transição governamental (SPINK, 1987).

Assim como organizações e qualquer outro sistema socialmente construído, as políticas públicas também são encerradas, e conforme apontam Souza e Secchi (2015), é fundamental compreender sua extinção.

A avaliação, fase que precede a extinção ou continuidade da política, é extremamente relevante pois permite mensurar os resultados e verificar a necessidade ou não de descontinuidade, o que sugere que os governantes devem ater-se às análises e avaliações políticas. Nesse aspecto, é importante ressaltar que se mal planejadsa ou executadas, as políticas podem atingir negativamente as pessoas.

Como sugere Spink (1987), a expressão descontinuidade diz respeito aos dilemas, práticas e contradições da Administração Pública, em particular, a cada troca de governos e de dirigentes. "Como fenômeno a descontinuidade, manifesta-se pelas consequências organizacionais de preencher um sem-número de cargos de confiança, explícita ou implicitamente disponíveis para distribuição no interior de organizações públicas" (SPINK, 1987, p. 1).

Nesse sentido, um fenômeno capaz de interromper políticas e programas em desenvolvimento é a mudança de gestores a cada troca de governo, traduzindo-se em descontinuidade administrativa (NOGUEIRA, 2006). A descontinuidade decorrente da troca de políticos e gestores resulta na "interrupção de projetos, obras e ações, e na reversão de prioridades e metas" (NOGUEIRA, 2006, p. 6). Essas rupturas comumente são consideradas indesejáveis, pois consequentemente resultam na perda de conhecimento, a chamada memória institucional, "na reversão de avanços, na descrença ou desmotivação por parte dos envolvidos, e também num provável desperdício de recursos públicos investidos" (NOGUEIRA, 2006, p. 6). 
As trocas de governo são consideradas como momentos em que "naturalmente tudo vai mudar, e atividades e programas serão rompidos, independentemente de política pública, partido ou sua efetividade anterior" (SPINK; CLEMENTE; KEPPKE, 1997, p. 13). Dificuldades desse processo de troca são vistas em locais em que há um relevante número de cargos de confiança, visto que, ao realizar a troca dos ocupantes, há um período considerável até que ocorra a adaptação, de maneira geral, entre os últimos seis meses de um governo e o primeiro semestre do próximo.

O momento posterior à realização das eleições é considerado um período de insegurança para beneficiários, parceiros e agentes públicos, pois, conforme apontam Caldas e Ávila (2013), há a dúvida se os novos governantes ou as novas equipes de antigos governantes darão continuidade aos programas. É importante apontar que a resistência das políticas públicas à extinção está atrelada a sua importância não apenas para a administração pública, mas também para a sociedade civil como um todo.

\section{Fluxos múltiplos}

Uma questão fundamental ao se debruçar sobre as teorias de políticas públicas, é sobre como e o que faz com que determinado tema seja prioridade para os formuladores de políticas. Por que alguns temas e não outros? Como já exposto anteriormente, o momento em que os policy makers dão atenção a determinado assunto, este é denominado “agenda". Kingdon (2006b) reflete que a agenda é a lista de temas ou problemas, que estão em foco tanto para as autoridades governamentais, como para pessoas fora do governo.

Além dos temas que estão na agenda, os responsáveis pelas políticas precisam especificar ainda as alternativas para resolução dos problemas. Esse processo de especificação de agenda e possíveis soluções restringe as inúmeras alternativas que existem no mundo político. Kingdon (2006b) aponta que em grande parte da literatura atual, o "estabelecimento da agenda" se refere aos processos de agenda e alternativas. Enquanto acadêmicos defendem que "a agenda" é dominada por profissionais especialistas e técnicos, outros apontam que ela é determinada por grandes problemas (com grande visibilidade) e pelas escolhas de governantes. Conforme exposto por Kingdon (2006b), é possível considerar que os especialistas são mais importantes no 
processo de geração de alternativas e governantes tem maior controle sobre o estabelecimento das agendas.

Consoante ao que Kingdon (2006b) define, existem três processos que influenciam o estabelecimento de agendas: a dinâmica dos problemas, das soluções e da política (ou "humor nacional"). A junção desses três fluxos, denominada fluxos múltiplos, permite a abertura de uma janela de oportunidade (policy window) que permite a criação da política pública, como é possível observar na Figura 3, na qual Capella (2006) sintetiza o modelo de Kingdon (2006b).

Figura 3 - Dinâmica criada por Capella que exemplifica a criação de uma política pública pela integração dos fluxos múltiplos criados por Kingdon.

O Modelo de Kingdon

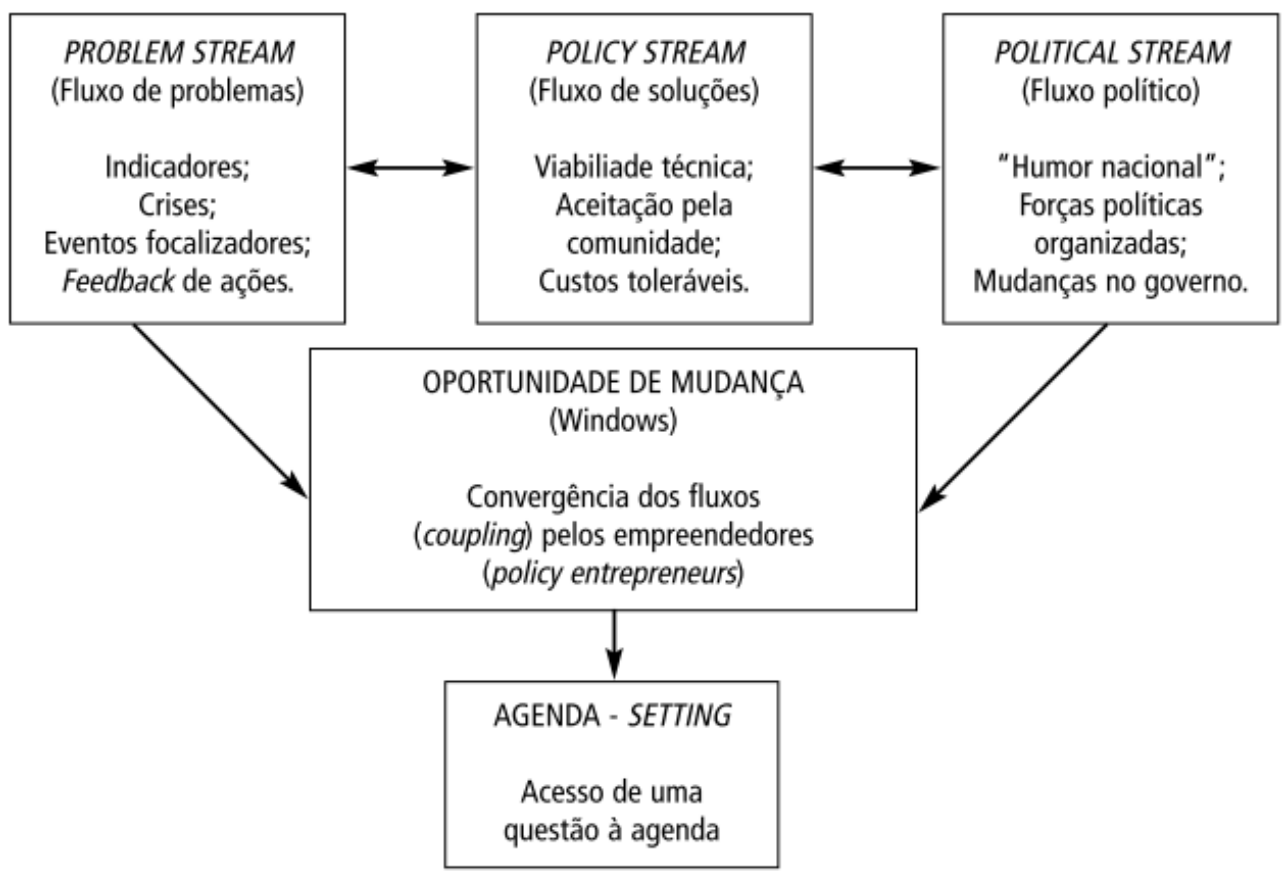

Fonte: Capella (2006, p. 32)

\section{Problemas}

A evidência que alguns problemas adquirem em detrimento a outros, está relacionada aos meios pelos quais os atorem tomam conhecimento das situações (KINGDON, 2006a). Com relação aos meios, conforme Kingdon (2006a, p. 227), são discutidos os indicadores, os eventos-foco e o feedback: 
Indicadores: os indicadores são utilizados para quantificar a magnitude de uma determinada situação, ou mesmo, verificar as possíveis mudanças ocorridas.

Evento-foco: um problema considerado um evento-foco origina de um desastre, uma crise, uma experiência pessoal ou um símbolo poderoso. No entanto, é importante ressaltar que caso não exista indicações precisas para determinado problema, os eventos-foco tem efeito passageiro.

Feedback: os feedbacks auxiliam para que uma situação fique em evidência, pois, a partir deles, os responsáveis por elaboração das políticas podem ter conhecimento da real situação de programas já existentes.

Apesar da compreensão de que um problema é a diferença entre uma situação atual e uma situação considerada ótima para a realidade, a definição de situação em problema por parte do governo e sociedade civil, pode ser feita de inúmeras formas (KINGDON, 2006a):

- Em primeiro lugar, podem ser consideradas problemas aquelas situações que "colocam em cheque valores importantes" (KINGDON, 2006a, p. 227).

- Segundo, o resultado das comparações entre outros países e unidades podem transformar situações em problemas.

- Terceiro, "a classificação de uma situação em uma certa categoria ao invés de outra pode defini-la como um certo tipo de problema" (KINGDON, 2006a, p. 228).

Convém apontar, que as agenda são capazes ainda de fazer os problemas desaparecerem pela falta de atenção. Além disso, é importante compreender que as pessoas não podem estar atentas a todos os problemas em todo o tempo.

\section{$\underline{\text { Ambiente político }}$}

A dinâmica política é capaz de criar o clima favorável para a criação ou extinção das políticas públicas, o denominado "humor nacional”. Caso as ideias estejam bem construídas, com boas argumentações e bem defendidas pelos seus autores, estas podem chegar à agenda, desde que o contexto seja favorável. É importante estar atento ainda para as mudanças no governo, que propiciam as alterações dos indivíduos em posições estratégicas na estrutura governamental, potencializando a emergência de algumas ideias, ou mesmo, limitando outras (CAPELLA, 2015).

Ressaltando a importância dos desdobramentos políticos e mudanças de governo, Kingdon (2006a, p. 229) aponta que "um novo governo, por exemplo, muda as agendas completamente ao enfatizar as suas concepções dos problemas e suas propostas, e torna bem menos provável que assuntos que não estejam entre as suas prioridades recebam atenção". Inclusive, tais mudanças podem influir na formação das agendas, 
independentemente do reconhecimento de um problema ou mesmo no desenvolvimento de alternativas.

A forma como o consenso é formado na dinâmica da política dá-se mais por negociação que pela persuasão. A negociação é formada por meio de negociações, emendas em trocas de apoio, alianças ou mesmo concessões (KINGDON, 2006a). Mais poderoso que as negociações entre grupos de interesses é a combinação da vontade nacional com as eleições.

Os atores que recebem uma significativa atenção da impressa e do público são os participantes visíveis, que incluem "o presidente e seus assessores de alto escalão, importantes membros do Congresso, a mídia, e atores relacionados ao processo eleitoral, como partidos políticos e comitês da campanha" (CAPELLA, 2006; KINGDON, 2006a, p. 230). Por outro lado, os participantes invisíveis são os acadêmicos, burocratas de carreira e funcionários do Congresso. "O trabalho desses participantes consiste em planejamento e avaliação, ou então em formulações orçamentárias junto à burocracia e aos seus funcionários" (KINGDON, 2006a, p. 231). Ou seja, os participantes visíveis definem a agenda, enquanto os atores invisíveis influenciam na escolha das alternativas.

Inúmeras ideias são geradas por esses atores visíveis e invisíveis, que podem ser sugeridas por discursos, projetos de lei, audiências, conversas e outros. Tais propostas podem ser atacadas ou mesmo descartadas, no entanto, algumas, de certa forma, podem ser consideradas durante o processo.

\section{$\underline{\text { Soluções }}$}

As ideias ou possíveis soluções não surgem de maneira linear e concisa ao aparecimento dos problemas. As ideias podem interagir umas com as outras gerando novas ideias, combinações e recombinações.

O processo de seleção das ideias inclui "viabilidade técnica, congruência com os valores dos membros da comunidade de especialistas, e a antecipação de possíveis restrições, incluído as orçamentárias, aceitabilidade do público e receptividade dos políticos” (KINGDON, 2006a, p. 232). A avaliação das propostas, desse modo, leva em consideração a situação política, porém, é baseada também em critérios lógicos e analíticos (KINGDON, 2006a). 
Desse modo, os empreendedores de políticas públicas (policy entrepreneurs) ${ }^{5}$ levam sempre em consideração suas propostas favoritas. Nesse processo de escolha de alternativas para políticas públicas, é mais comum e importante a reelaboração das propostas que o surgimento de novas (KINGDON, 2006a).

\title{
Conexão e janelas
}

Em alguns momentos, os fluxos de problemas, político e da dinâmica de alternativas se unem. Embora cada fluxo tenha sua dinâmica própria, em dado instante, por exemplo:

\begin{abstract}
um evento político, como a mudança de governo, gera mudanças de direção. Nesse momento, as propostas que podem ser relacionadas com aquele evento político, tais como as iniciativas em linha com a filosofia da nova administração, são destacadas e associadas ao novo contexto político já amadurecido. De forma similar, os problemas que se encaixam na nova ótica são enfatizados, enquanto outros são desprezados (KINGDON, 2006a, p. 233).
\end{abstract}

O momento de congruência dos três fluxos é propício para que os empreendedores de políticas públicas que estão atentos a determinado problema, aproveitem o contexto político para que busquem, ainda, propostas para a solução do problema. Convém ressaltar que em certos momentos podem ocorrer associações parciais, ou seja, soluções podem surgir para problemas que não possuem receptividade em dado momento, ou até mesmo, para um problema urgente atrelado a um momento político, porém sem que tivesse havido uma alternativa (KINGDON, 2006a).

A confluência dos fluxos cria, desse modo, uma janela de oportunidades, para o lançamento das soluções. A abertura dessa janela é propicia para que o problema se torne prioritário na agenda governamental, permitindo que os formuladores de política estejam atentos a essa questão. As janelas podem ser abertas tanto por eventos que estejam

\footnotetext{
${ }^{5}$ Os policy entrepreneurs são pessoas dispostas a investir recursos para promover políticas que possam lhes favorecer. Eles são motivados por combinações de diversos elementos: preocupação direta com certos problemas, busca de benefícios próprios, tais como proteger ou aumentar seu orçamento burocrático, reconhecimento pelas suas realizações, promoção de seus valores e o mero prazer de participar. São encontrados em três conjunturas: quando tentam colocar suas preocupações a respeito de certos problemas no topo da agenda, quando promovem suas propostas favoritas durante um processo de amaciamento do sistema e quando fazem as conexões. Esses entrepreneurs podem ser: políticos eleitos, funcionários públicos de carreira, lobistas, acadêmicos ou jornalistas (KINGDON, 2006a, p. 238). Com relação às conexões, os entrepreneurs aparecem quando janelas se abrem. Eles têm suas propostas favoritas e suas preocupações sobre problemas, e os trazem à tona no momento propício. Na busca de seus objetivos, eles desempenham no sistema a função de unir soluções e problemas, problemas a forças políticas, e forças políticas a propostas (KINGDON, 2006a, p. 239).
} 
ocorrendo durante a dinâmica dos problemas, quanto da política. Assim, conforme aponta Kingdon (2006a, p. 237), há janelas de problemas e janelas na política:

Por exemplo, um novo problema surge, criando a oportunidade de se propor uma solução para ele. Ou eventos na dinâmica política, tais como a eleição de novos políticos, mudança no clima político-nacional, ou um lobby poderoso, podem criar oportunidades de trazerem se à tona alguns problemas e propostas e, consequentemente, reduzir as chances de outros problemas e propostas.

\section{As Políticas Públicas de $3^{\text {a Geração }}$}

Anterior às mudanças governamentais que provocaram o início do reconhecimento aos agricultores familiares, o Brasil do pós-guerra caracterizava-se como um país voltado para a alta produtividade agrícola, a chamada Revolução Verde. Tal Revolução é caracterizada pelos avanços tecnológicos, com o intuito de intensificar a oferta de alimentos. Esse novo modo de produção é entendido como um novo paradigma em contraposição ao modo de produção agrícola, criada a partir do século XVIII, baseando sua produção para a exportação.

De acordo com Pereira (2012), tal revolução foi concebida como um pacote tecnológico, composto por insumos químicos, sementes de laboratório, irrigação, mecanização e grandes extensões de terra, com vistas a valorizar e garantir o progresso. O progrsso nessa época era marcado por grandes produções agrícolas que visavam a exportação dos alimentos, fomentando a economia principalmente de grandes produtores.

Inúmeros defensores desse pacote tecnológico consideravam-no como o responsável pela solução da crise dos alimentos. Em parte, essa tecnologia genéticoquímica obteve sucesso ao gerar grande produtividade em meados dos anos 1960, período marcado pela intervenção do Estado na agricultura e meio rural. Porém, tal êxito acarretou diversos problemas como mudanças estruturais no campo, perda de variedades antigas, perda de material genético e redução de alternativas alimentícias (PEREIRA, 2012).

Além dos danos causados à diversidade biológica, esse novo paradigma transformou a base da agricultura na medida em que o conhecimento milenar prático do próprio agricultor foi substituído pelo conhecimento científico; os ciclos ecológicos locais, pautados nos recursos endógenos, foram substituídos por insumos exógenos industriais; o trabalho que era realizado em convivência com a natureza foi fragmentado em partes - agricultura, pecuária, natureza, sociedade -, e cada esfera passou a ser considerada em separado, quebrando-se a unidade existente entre ser humano e natureza 
(PEREIRA, 2012). Essas intervenções alteraram o padrão tecnológico dos agricultores, construindo novas dinâmicas produtivas e econômicas (GRISA, 2012).

A transformação da base da agricultura acarretou efeitos colaterais catastróficos para o meio ambiente. Conforme enunciado por Lacey (2008, p. 203), as principais perdas ambientais são: "esgotamento e envenenamento dos solos, perda de variedade no repositório genético das sementes, perturbação dos cursos d'água, desertificação e dependência de fertilizantes".

Alheio aos problemas criados pela Revolução Verde, o país orientou-se então, por uma modernização da agricultura para cumprir com o desenvolvimento econômico. Foram elaboradas diversas políticas e ações para fomentar ainda mais o desenvolvimento agrícola, como o "crédito rural, garantia de preços mínimos, seguro agrícola, subsídios à aquisição de insumos, desenvolvimento de infraestruturas" e outros (GRISA; SCHNEIDER, 2015b, p. 24).

Ainda que tais políticas e ações desenvolvidas pelo Governo brasileiro para impulsionar o setor agropecuário não indicassem os seus principais beneficiários, conforme apontam Grisa e Schneider (2015b, p. 25), esses instrumentos apresentaram-se com um caráter seletivo. Os principais beneficiários foram "os médios e os grandes agricultores, localizados nas regiões sul e sudeste, produtores direcionados à exportação ou de interesses de grupos agroindustriais". Além do caráter excludente dessas ações, a estratégia imposta gerou inúmeros outros problemas e não conseguiu atingir um de seus objetivos principais, ou seja, não foi possível alcançar o abastecimento alimentar interno, além de provocar o aumento da inflação.

Com as críticas ao sistema imposto e à exclusão de inúmeros setores, as mudanças na forma de beneficiar outros agricultores e buscar uma outra forma de produção agropecuária, só foram iniciadas a partir dos anos 1980 e principalmente com a Constituição Federal em 1988. Apenas a partir da redemocratização brasileira, os representantes dos pequenos agricultores conseguiram adentrar a arena política.

A luta pela política agrícola diferenciada para os agricultores familiares teve maior alcance nacional pela esfera social a partir da década de 1990, período do Governo Collor, primeiro presidente eleito após o regime militar (MATTEI, 2016). Desse modo, essa classe que havia começado a ganhar evidência após a Constituição de 1988, teve maior 
destaque nas "Jornadas Nacionais de Luta", na primeira metade da década de 1990 e que, a partir de 1995, passaram a ser denominadas "Grito da Terra Brasil" (MATTEI, 2016).

Embora com um início de representatividade após o governo Collor, é fundamental apontar que em meio aos "vinte anos de ditadura militar, os representantes da sociedade civil vinculados à agricultura familiar não encontraram espaço na arena pública para discutir e construir, em conjunto com os gestores públicos, políticas para a categoria social" (GRISA; SCHNEIDER, 2015b, p. 24).

O movimento e organização dessa classe trabalhadora rural proporcionaram um novo protagonismo político, principalmente em meados do século $\mathrm{XX}$, o que propiciou a reivindicação de ações e políticas públicas por parte dos governantes constituídos (MATTEI, 2016).

O "surgimento" desses problemas que os agricultores familiares há muito vêm enfrentando não ocorreu subitamente, porém, a partir de inúmeras lutas de atores já citados. O reconhecimento político e insitucional do Brasil à agricultura familiar é marcado pela institucionalização do Programa Nacional de Fortalecimento da Agricultura Familiar (Pronaf), em 1995, durante o governo do ex-presidente Fernando Henrique Cardoso.

Maior ênfase, no entanto, foi dada a essa classe após o primeiro mandato do expresidente Luís Inácio Lula da Silva. Em meados de 2003, quando foram fomentadas práticas com vistas a dirimir os problemas, como por exemplo os seguintes programas Programa de Aquisição de Alimentos (2003); Programa Nacional de Alimentação Escolar (2009); Programa Nacional de Segurança Alimentar e Nutricional (PLANSAN) (2003); Programa 1 milhão de Cisternas Rurais (2003) (MATTEI, 2016). A criação dessas políticas em meio à agenda afirmativa para a agricultura familiar durante a ascensão do do ex-presidente indica que tal categoria não era vista mais apenas como uma categoria, mas sim como uma classe ativa na economia (MATTOS, 2017).

Corroborando com o exposto acima, Mattei (2016) enfatiza também que as ações públicas que contribuíram para a produção agropecuária do país e para a tentativa de proporcionar vida digna a uma parte da população foram implantadas ao longo da primeira década do século XXI. Desse modo, 
também a diversos segmentos sociais até então praticamente invisíveis às políticas de desenvolvimento rural (MATTEI, 2016, p. 5).

Foi somente no ano de 2006, com a promulgação da Lei $\mathrm{n}^{\circ} 11.326$, de 24 de julho do referido ano, que o Brasil passou a ter uma lei da Agricultura Familiar, que estabeleceu a Política Nacional de Agricultura Familiar e definiu quais eram os seus beneficiários. A partir dessa definição foi possível reconhecer formalmente a diversidade dos agricultores familiares, incorporando outros públicos, como por exemplo povos e comunidades tradicionais, pescadores artesanais, entre outros. De acordo com a Lei ${ }^{\circ} 11.326 / 2006$, o agricultor familiar é assim definido:

Art. $3^{\circ}$ Para os efeitos desta Lei, considera-se agricultor familiar e
empreendedor familiar rural aquele que pratica atividades no meio rural,
atendendo, simultaneamente, aos seguintes requisitos:
I-não detenha, a qualquer título, área maior do que 4 (quatro) módulos fiscais;
II - utilize predominantemente mão de obra da própria família nas atividades
econômicas do seu estabelecimento ou empreendimento;
III - tenha renda familiar predominantemente originada de atividades
econômicas vinculadas ao próprio estabelecimento ou empreendimento;
IV-dirija seu estabelecimento ou empreendimento com sua família (BRASIL,
2006a).

É importante ressaltar, no entanto, que o conceito de agricultura familiar extrapola a definição territorial apresentada pela Lei governamental. Conforme apresentado por Neves (2012), o termo apresenta múltiplas conotações: corresponde a uma organização produtiva; a princípios de gestão das relações de produção e trabalho sustentadas em relações entre membros da família; corresponde a formas de organização em que a família é ao mesmo tempo proprietária dos meios de produção e executora das atividades e ainda com práticas de criação de valor agregado aos produtos.

A Lei $\mathrm{n}^{\circ}$ 11.326/2006 permitiu que o Brasil se tornasse referência internacional nas políticas para agricultura familiar (CAMPOS; BIANCHINI, 2014). A partir disso, foi elaborado um conjunto de políticas públicas que buscam implementar ações que contribuam para o dinamismo da Agricultura Familiar no país. Iniciativas como o Pronaf a criação de mercados institucionais como o Programa de Aquisição de Alimentos (PAA), a reformulação do Programa Nacional de Alimentação Escolar (PNAE), a reestruturação dos serviços de Extensão Rural, a partir da Política Nacional de Assistência Técnica e Extensão Rural (PNATER) e da lei de ATER (Lei 12.188 de janeiro de 2010), são importantes instrumentos nesse contexto (SÃO JOSÉ; PEREIRA; OLIVEIRA, 2017). 
Com a criação de políticas que incentivem a agricultura familiar, aos poucos a realidade desses agricultores foi sendo modificada e eles têm sido reconhecidos como um segmento importante dentro do cenário econômico e produtivo nacional e para a própria segurança alimentar e nutricional dos brasileiros. Além de poder prover a segurança alimentar e nutricional, os agricultores familiares vem contribuindo para o desenvolvimento sustentável. Além da promulgação da Lei $\mathrm{n}^{\circ} 11.326 / 2006$, outro fator importante para os agricultores familiares foi, que o ano de 2014, foi declarado pela Organização das Nações Unidas (ONU) como o Ano Internacional da Agricultura Familiar (AIAF) (BRASIL, 2016c). Tal reconhecimento está baseado em um processo político e social de afirmação da identidade e das reivindicações de diversos segmentos sociais, com experiências diferentes de acesso e uso dos recursos naturais.

Grisa e Schneider (2015b) fizeram uma análise da trajetória das políticas públicas para a agricultura familiar enfatizando três gerações (momentos chaves), que marcaram a relação entre o Estado e a sociedade civil. Esse referencial é um dos pilares para o desenvolvimento deste estudo, com ênfase maior a algumas políticas da terceira geração.

A primeira geração de políticas públicas voltadas para a agricultura familiar é marcada pela criação de políticas públicas com ênfase no viés agrário e agrícola, como o Pronaf, uma política de crédito rural; a criação do Seguro da Agricultura Familiar no ano de 2014 (SEAF); o Programa de Garantia de Preço da Agricultura Familiar (PGPAF), lançado em 2006; a retomada da Assistência Técnica e Extensão Rural (ATER) e as políticas para assentamentos de Reforma Agrária. Essa geração é marcada pelos seguintes atores: representantes sindicais e movimentos sociais da agricultura familiar, políticos e gestores públicos e os estudiosos do mundo rural (GRISA; SCHNEIDER, 2015b)

As três classes de atores que marcaram a primeira geração, foram também os responsáveis por instituir a segunda, no entanto, com o acréscimo de uma nova classe, os representantes do agronegócio. Essa geração, de acordo com Grisa e Schneider (2015b), focava o combate à pobreza rural e urbana, como forma de corrigir as falhas de mercado. Visando o combate a essas desigualdades, foram criadas políticas como: o Pronaf Infraestrutura, a Garantia Safra, a Política Nacional de Habitação Rural (PNHR), o Programa Nacional de Desenvolvimento Sustentável de Territórios Rurais (Pronat) e o Bolsa Família.

Com um referencial voltado à construção de mercados, a terceira geração contou ainda com os mesmos atores que foram fundamentais às outras duas gerações, no entanto, 
os estudiosos voltados ao mundo rural, somaram-se aos estudiosos da segurança alimentar e nutricional, além de ter ênfase também as organizações do campo agroecológico e as organizações da sociedade civil vinculados ao tema da segurança alimentar e nutricional. Esses atores foram os responsáveis pela proposição das políticas que qualificariam a agricultura familiar como um meio de promover o acesso da sociedade aos alimentos por meio de programas como: o Programa de Aquisição de Alimentos (PAA), Programa Nacional de Alimentação Escolar (PNAE), Política de Garantia de Preço Mínimo para os Produtos da Sociobiodiversidade (PGPMBio), Programa Nacional de Produção e Uso do Biodiesel (PNPB) e os selos e codificações que agregariam valor aos produtos oriundos da agricultura familiar. Uma breve síntese das três gerações é apresentada na Figura 4.

Figura 4 - Resumo das três gerações de políticas públicas voltadas para a agricultura familiar, com a ênfase dada em cada geração e os principais programas lançados.
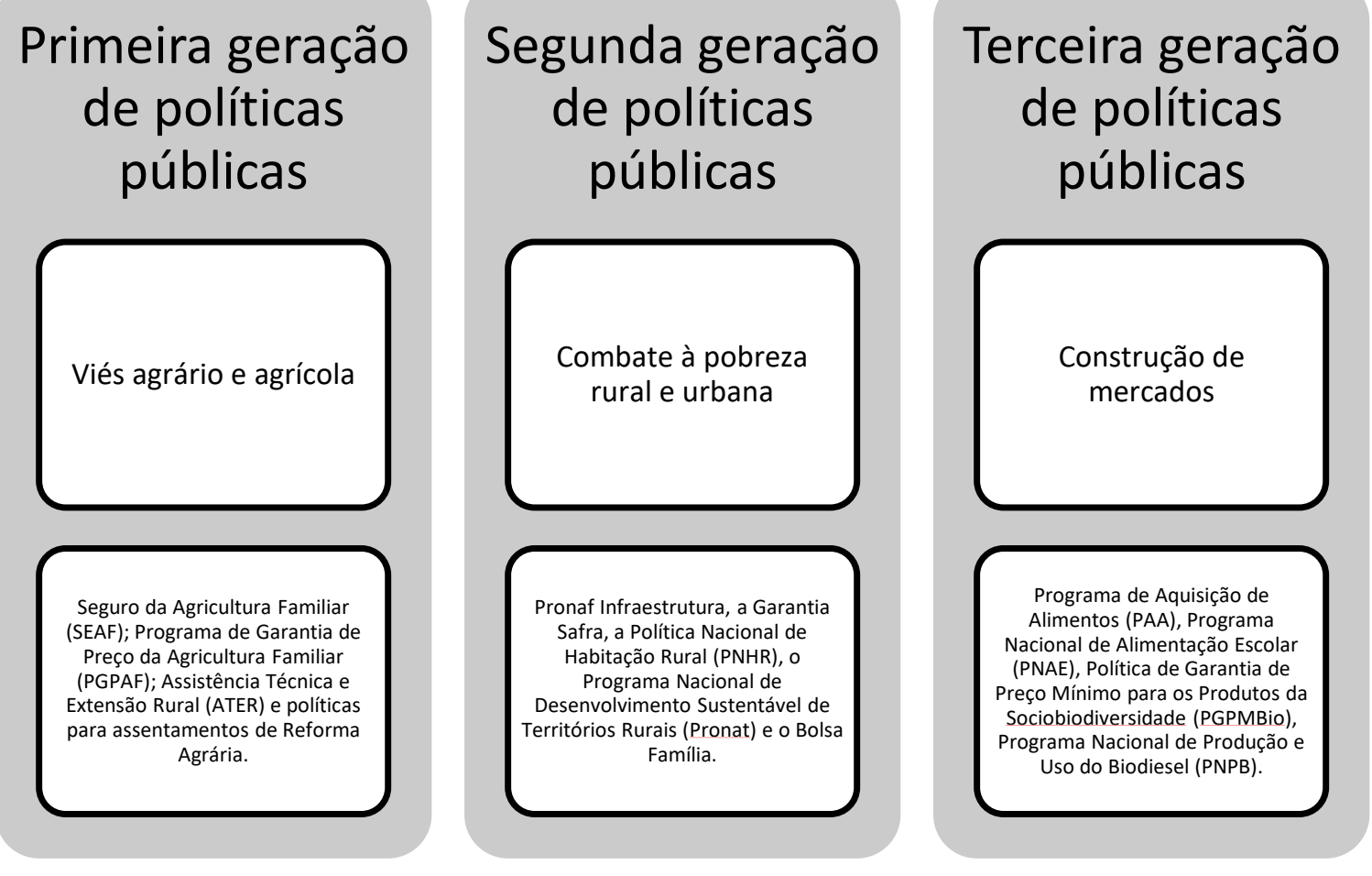

Fonte: Grisa e Schneider (2015b).

Convém ressaltar que os problemas reconhecidos pelo governo brasileiro ao promover a construção dessas políticas públicas não esgotaram e nem mesmo sanaram as dificuldades enfrentadas pelos agricultores. Esses agricultores continuaram a enfrentar dificuldades de se manter no campo, acessar as políticas, ter acesso a educação, saúde e moradia de qualidade, alimentação saudável e regular e muitos outros. 
As políticas de fomento aos agricultores passaram por inúmeros avanços, porém, conforme apontado por Grisa (2010), algumas políticas apresentam caratér seletivo. Como possível método para acesso às políticas públicas, a Organização das Nações Unidas para a Alimentação e a Agricultura (FAO/ONU) aponta as cooperativas e as associações como resposta a uma melhor inserção aos mercados, e como ferramentas para “ampliar a contribuição da agricultura familiar nas ações voltadas à superação da pobreza, ao combate à fome, à garantia da segurança alimentar e nutricional, ao crescimento econômico e ao desenvolvimento sustentável dos países" (BRASIL, 2016d, p. 103).

Com o avanço no reconhecimento dos agricultores familiares por parte do Estado, foi criado, em 1999, o Ministério do Desenvolvimento Agrário (MDA) (MATTEI, 2016). O MDA propiciou ainda mais a criação de políticas públicas destinadas ao fortalecimento desse sistema familiar de produção e outras classes excluídas nas relações entre sociedade e Estado. A esse Ministério foi atribuída a coordenação e execução das políticas que tinham como objetivo promover o "desenvolvimento rural sustentável; a realização da reforma agrária; a promoção e fortalecimento da agricultura familiar do país; a implementação da produção orgânica e agroecológica; e a promoção da segurança alimentar e nutricional da população brasileira" (MATTEI, 2016, p. 8).

Essas políticas e programas de apoio à agricultura familiar e promoção da segurança alimentar proporcionaram ao Brasil notoriedade internacional ainda que diante de inúmeras as tensões, conflitos e contradições para essa classe (MALUF, 2015, p. 10).

Dessa maneira, as mudanças do Estado indicam que "nas décadas de 1980 e 90, com o ajuste estrutural e o neoliberalismo, a atuação do Estado e das políticas públicas são modificadas e minimizadas, ganhando maior proeminência a atuação do mercado e da sociedade civil no desenvolvimento". Por outro lado, os anos 2000 apresentaram um cenário complexo e multifacetado. A criação das políticas públicas para a agricultura familiar passou então a considerar a diversidade e complexidade do setor agrícola, que engloba diversas categorias sociais (GRISA; SCHNEIDER, 2015a).

Além da diversidade que as políticas públicas para a agricultura familiar enfrentam, elas devem considerar ainda o agricultor familiar como um pequeno empresário, que precisa produzir de maneira qualificada para que possa atender a inúmeros consumidores. Nesse aspecto, com o intuito de ampliar a demanda dos produtos para a agricultura familiar, as políticas públicas de terceira geração criaram diversos mercados que abrangem tal classe. Três desses mercados estão abaixo delineados: 


\section{Programa de Aquisição de Alimentos - PAA}

Foi a partir de seu primeiro mandato que o Presidente Lula estabeleceu como prioridade de governo o combate à fome e à pobreza no país, implementando o Programa Fome Zero, "combinando ações emergenciais e estruturais e estimulando a participação e a mobilização social, como parte da estratégia de constituição de um amplo mercado interno e de democratização da sociedade brasileira" (BRASIL, 2016e, p. 1). Para poder implementar essa estratégia, foi criado no ano de 2003 o Programa de Aquisição de Alimentos - PAA.

O PAA, instituído pelo artigo dezenove da Lei $\mathrm{n}^{\circ}$ 10.696/2003 e regulamentado pela Lei $\mathrm{n}^{\circ} 12.512 / 2011$, visa:

I - incentivar a agricultura familiar, promovendo a sua inclusão econômica e social, com fomento à produção com sustentabilidade, ao processamento de alimentos e industrialização e à geração de renda;

II - incentivar o consumo e a valorização dos alimentos produzidos pela agricultura familiar;

III - promover o acesso à alimentação, em quantidade, qualidade e regularidade necessárias, das pessoas em situação de insegurança alimentar e nutricional, sob a perspectiva do direito humano à alimentação adequada e saudável;

IV - promover o abastecimento alimentar, que compreende as compras governamentais de alimentos, incluída a alimentação escolar;

V - constituir estoques públicos de alimentos produzidos por agricultores familiares;

VI - apoiar a formação de estoques pelas cooperativas e demais organizações formais da agricultura familiar; e

VII - fortalecer circuitos locais e regionais e redes de comercialização (BRASIL, 2011).

A política do PAA dá maior atenção aos agricultores que fazem parte do PRONAF, bem como aos pescadores artesanais, aos silvicultores, aos extrativistas, aos aquicultores, aos indígenas, aos quilombolas e aos agricultores assentados. Desse modo, o programa fortalece e impulsiona a produção da agricultura familiar e também as cooperativas e associações que fazem parte do PAA (SÃO JOSÉ; PEREIRA; OLIVEIRA, 2017). Aperfeiçoado durante o governo da ex-presidente Dilma Rousseff, o PAA inova porque assume duas funções fundamentais: fortalecer a agricultura familiar por meio da comercialização, e promover o acesso a alimentos para aqueles que se encontram em situações de insegurança alimentar, ultrapassando o aspecto apenas setorial da agricultura (AVILA; CALDAS; ASSAD, 2013; BRASIL, 2014b). 
Uma das singularidades do PAA é que o programa não se constitui em uma ação isolada e descontextualizada, pois, grande parte de seu sucesso é viável porque "os agricultores familiares estão inseridos e apoiados por outros programas, que lhe permitem produzir, organizar-se e comercializar sua produção com o governo" (CAMPOS; BIANCHINI, 2014, p. 15).

Inicialmente, o PAA passou a ser executado com recursos do Ministério do Desenvolvimento Social e Combate à Fome (MDS) e do Ministério do Desenvolvimento Agrário (MDA), tendo a Companhia Nacional de Abastecimento (Conab) como importante parceira. Desse modo, na gestão do Programa foi instituído o caráter intersetorial por meio do Grupo Gestor, formado por representantes do MDS, do MDA, do MAPA, do MEC, do Ministério da Fazenda e do Ministério do Planejamento e Gestão (MPOG) (PORTO, 2016a). Já no ano de 2017, após as mudanças governamentais, o programa passou a ser executado com recursos da Secretaria Especial de Agricultura Familiar e Desenvolvimento Agrário (Sead) e do Ministério do Desenvolvimento Social e Agrário (MDSA) e que em 2017 passou a ser nomeado como Ministério do Desenvolvimento Social (MDS), em parceria com estados, municípios e com a Companhia Nacional de Abastecimento (Conab).

Os fornecedores para o PAA são os agricultores familiares, conforme disposto pela Lei $n^{\circ} 11.326 / 2006$ e demais beneficiários. Ainda no que concerne ao que está expresso na Lei, é estabelecido que as aquisições dos produtos podem ser efetuadas diretamente dos beneficiários, ou indiretamente, por meio de cooperativas e demais organizações formais.

A aquisição dos produtos produzidos pelos beneficiários do PAA pode ocorrer com dispensa de licitação, desde que:

I - os preços sejam compatíveis com os vigentes no mercado, em âmbito local ou regional, aferidos e definidos segundo metodologia instituída pelo Grupo Gestor do PAA;

II - o valor máximo anual ou semestral para aquisições de alimentos, por unidade familiar, por cooperativa ou por demais organizações formais da agricultura familiar seja respeitado, conforme definido em regulamento; e

III - os alimentos adquiridos sejam de produção própria dos beneficiários referidos no caput e no $\S 1$ o do art. 16 desta Lei e cumpram os requisitos de controle de qualidade dispostos nas normas vigentes (BRASIL, 2011). 
Ressaltando ainda mais o diferencial e a inovação do Programa, os produtos adquiridos para o PAA podem ter as seguintes destinações: garantir a segurança alimentar e nutricional, formar estoques e atender as demandas de gêneros alimentícios por parte da administração pública (BRASIL, 2011). São cinco as modalidades de compra do PAA: Compra da agricultura familiar para doação simultânea; formação de estoques pela agricultura familiar - CPR Estoque; Compra direta da agricultura familiar - CDAF; Incentivo à produção de leite - PAA Leite; e Compra Institucional.

(1) O PAA Compra da agricultura familiar para doação simultânea, cujas formas de acesso podem ser individual ou por organizações, recebe recursos do MDS, sendo o limite de $\mathrm{R} \$$ 4,5 mil/mês para o agricultor individual e $\mathrm{R} \$ 4,8 \mathrm{mil} / \mathrm{mês}$ para organizações. Os produtos adquiridos da agricultura familiar por meio desse programa são destinados à doação para pessoas em situação de insegurança alimentar e nutricional.

(2) O PAA Formação de estoques pela Agricultura Familiar - CPR Estoque, acessado apenas por organizações, também conta com recursos de origem no MDS/MDA, sendo o limite de R 8 mil/mês. Essa ação é responsável por disponibilizar recursos para que organizações da agricultura familiar formem estoques de produtos para posterior comercialização.

(3) Para o PAA Compra Direta da Agricultura Familiar - CDAF, o acesso pode ser individual ou por organizações, sendo que o recurso tem origem via MDS/MDA e seu limite é de R $\$ 8$ mil/mês. A CDAF é voltada à aquisição de produtos em situação de baixa de preço ou em função da necessidade de atender a demanda de alimentos de populações em condição de insegurança alimentar.

(4) O Incentivo à Produção e Incentivo de Leite - PAA Leite tem como beneficiários tanto indivíduos quanto organizações. Seu recurso tem origem via MDS, sendo o limite de $\mathrm{R} \$ 4$ mil por semestre. Tal ação assegura a distribuição gratuita de leite em ações de combate à fome e à desnutrição de cidadãos que estejam em situação de vulnerabilidade social e/ou em estado de insegurança alimentar e nutricional, com atendimento apenas aos estados do Nordeste. 
(5) A última modalidade do PAA, Compra Institucional, com limite de R $\$ 8$ mil/mês, pode ser acessada por indivíduos ou organizações e tem como finalidade a compra voltada para o atendimento de demandas regulares de consumo de alimentos por parte da União, estados, Distrito Federal e municípios (BRASIL, [s.d.]).

Nesse sentido, o Programa é capaz de adquirir produtos para o fortalecimento da agricultura familiar e promover o acesso à alimentação pelas parcelas da população que se encontram em estado de insegurança alimentar (CAMPOS; BIANCHINI, 2014, p. 16). O PAA inovou ainda ao permitir o pagamento de alimentos orgânicos e agroecológicos com um valor de até $30 \%$ dos produtos convencionais e promover a aquisição de sementes crioulas e a disseminação de seu uso (PORTO, 2016a).

Ao promover a aquisição de produtos da agricultura familiar, o PAA é visto como um programa inovador que abrange um valor considerável de recursos. Conforme indicado na Tabela 2, o valor total de recursos aplicados na aquisição de produtos do PAA vem crescendo continuamente, mesmo que com oscilações a partir do ano de 2013. 
Tabela 2 - Evolução dos recursos SEAD/MDS aplicados na aquisição de produtos do PAA entre 2003 a 2016

Evolucão dos recursos SEAD/MDS aplicados na aquisicão de produtos do PAA de 2003 a 2016

\begin{tabular}{|c|c|c|c|c|c|c|}
\hline \multirow[t]{2}{*}{$\underline{\text { Ano }}$} & \multicolumn{5}{|c|}{$\underline{\text { Valor }}$} & \multirow[t]{2}{*}{$\underline{\text { Total }}$} \\
\hline & $\underline{\text { Centro-Oeste }}$ & $\underline{\text { Nordeste }}$ & $\underline{\text { Norte }}$ & $\underline{\text { Sudeste }}$ & $\underline{\text { Sul }}$ & \\
\hline$\underline{2003}$ & 12.238 .974 & 31.672 .408 & 12.386 .912 & 7.603 .665 & 17.639 .249 & 81.541.207 \\
\hline$\underline{2004}$ & 3.386 .094 & 42.307 .978 & 28.391 .528 & 8.903 .396 & 24.196 .831 & 107.185 .826 \\
\hline$\underline{2005}$ & 5.538 .352 & 34.745 .917 & 16.149 .222 & 13.876 .678 & 42.481 .492 & 112.791 .660 \\
\hline$\underline{2006}$ & 10.045 .899 & 54.857 .717 & 17.812 .507 & 32.440 .707 & 85.510 .564 & 200.667 .394 \\
\hline$\underline{2007}$ & 8.706 .953 & 56.116 .343 & 18.799 .859 & 42.080 .968 & 102.648 .840 & 228.352 .963 \\
\hline$\underline{2008}$ & 9.893 .516 & 80.838 .353 & 15.679 .112 & 73.486 .284 & 93.032 .175 & 272.929 .439 \\
\hline$\underline{2009}$ & 13.225 .303 & 102.830 .480 & 15.549 .939 & 78.842 .348 & 153.516 .158 & 363.964 .228 \\
\hline$\underline{2010}$ & 21.400 .943 & 121.858 .906 & 28.348 .787 & 79.151 .714 & 128.975 .115 & 379.735 .466 \\
\hline$\underline{2011}$ & 32.025 .103 & 153.674 .198 & 29.386 .137 & 111.741 .509 & 124.209.257 & 451.036 .204 \\
\hline$\underline{2012}$ & 43.282 .942 & 154.904 .344 & 36.045 .217 & 131.776 .716 & 220.557 .912 & 586.567 .131 \\
\hline$\underline{2013}$ & 24.075 .247 & 66.487 .273 & 22.938 .796 & 67.812 .376 & 43.203 .433 & 224.517 .124 \\
\hline$\underline{2014}$ & 31.155 .531 & 79.992 .989 & 37.860 .917 & 128.709 .065 & 60.286 .440 & 338.004 .942 \\
\hline$\underline{2015}$ & 29.589 .161 & 92.549 .198 & 33.399 .258 & 77.902 .561 & 54.075 .037 & 287.515 .216 \\
\hline$\underline{2016}$ & 17.187 .827 & 88.470 .743 & 27.873 .958 & 41.313 .390 & 22.730 .799 & 197.576 .718 \\
\hline TOTAL & 261.751 .844 & 1.161 .306 .846 & 340.622 .150 & 895.641 .376 & 1.173 .063 .303 & 3.832 .385 .520 \\
\hline
\end{tabular}

Além das inovações já apontadas, Campos e Bianchini (2014) reforçam que um outro grande resultado do PAA foi o fortalecimento da organização econômica da agricultura familiar. Visto que, grande parte dos recursos do Programa é executada por meio de compras de organizações, como associações e cooperativas. "O programa foi um dos principais instrumentos de fortalecimento do cooperativismo e do associativismo entre os agricultores familiares. Essas organizações, hoje, estão mais estruturadas, mais experientes e mais preparadas para lidar com os mercados" (CAMPOS; BIANCHINI, 2014, p. 18). A experiência adquirida com o PAA permitiu que as organizações ampliassem seu mercado, tanto para programas governamentais ou mesmo mercado privado.

É importante destacar a capacidade de o PAA promover a aquisição dos produtos da agricultura familiar de todas as regiões do país. O programa permite que seja viável trabalhar inclusive "em locais onde a organização econômica é precária, graças aos 
circuitos curtos de comercialização e abastecimento que são propiciados pelo programa (CAMPOS; BIANCHINI, 2014, p. 19)".

Como indica Porto (2016b), no ano de 2012 o PAA apresentou seu melhor resultado, executando mais de $\mathrm{R} \$ 586$ milhões de reais nas diferentes modalidades, conforme indicado na Tabela 3. Foram adquiridos 380 alimentos distintos de 129 mil famílias e distribuíddos para 18 mil organizações. Além desses números expressivos, o Programa aplicou $\mathrm{R}$ \$ 12,6 milhões para a compra de produtos agroecológicos e orgânicos.

Tabela 3 - Evolução da aquisição (valor em mil reais) das modalidades do Programa de Aquisição de Alimentos, dos anos 2009 a 2016.

Evolucão das modalidades do PAA de 2009 a 2016 (valor em mil reais)

\begin{tabular}{|c|c|c|c|c|c|c|c|c|}
\hline & $\underline{2009}$ & $\underline{2010}$ & $\underline{2011}$ & $\underline{2012}$ & $\underline{2013}$ & $\underline{2014}$ & $\underline{2015}$ & $\underline{2016}$ \\
\hline $\begin{array}{l}\text { Compra com Doação } \\
\text { Simultânea (CDS) }\end{array}$ & 150.375 & 272.458 & 362.993 & 395.009 & 176.410 & 286.447 & 241.263 & 183.993 \\
\hline Formação de Estoque (FE) & 46.572 & 47.196 & 59.770 & 95.105 & 28.627 & 31.801 & 20.799 & 9.572 \\
\hline $\begin{array}{l}\text { Compra Direta da } \\
\text { Agricultura Familiar } \\
\text { (CDAF) }\end{array}$ & 167.017 & 60.082 & 28.273 & 96.453 & 19.480 & 19.757 & 11.109 & 0 \\
\hline Sementes & 0 & 0 & 0 & 0 & 0 & 0 & 14.344 & 4.102 \\
\hline TOTAL & 363.9642010 & 379.735 & 451.036 & 586.567 & 224.517 & 338.005 & 287.515 & 197.577 \\
\hline
\end{tabular}

Fonte: Conab (2016).

A queda dos valores do Programa está atrelada em grande medida à instabilidade que o Programa sofreu a partir de 2013, por conta de medidas administrativas orientadas pelo Grupo Gestor. Dentre as mudanças convém indicar o repasse de recursos diretamente aos estados e municípios, restrição da atuação das organizações consumidoras e adoção de edital público para a aquisição das sementes crioulas (PORTO, 2016b).

\section{Programa Nacional de Alimentação Escolar-PNAE}

Considerado como um dos maiores programas de alimentação e nutrição do mundo, o Programa Nacional de Alimentação Escolar (PNAE) tem seu marco de fundação no ano de 1955 e atende diariamente aproximadamente 43 milhões de estudantes. O programa é executado pela sinergia entre o Ministério da Educação, o Fundo Nacional para o Desenvolvimento da Educação (FNDE) e os outros entes da federação, estados e municípios (BONDUKI, 2017).

O instrumento responsável por regulamentar o PNAE é a Lei n ${ }^{\circ} 11.947 / 2009$ que é considerada ainda um dos principais mecanismos de auxílio e fomento aos agricultores 
familiares. A inovação se dá pelo fato de a referida lei determinar que minimamente $30 \%$ do total de recursos financeiros repassados pelo FNDE sejam destinados a compra de alimentos oriundos da agricultura familiar (via empreendedor rural ou organizações) (SILVA; DIAS; AMORIM JUNIOR, 2015). A lei determina ainda que a compra poderia ser realizada por dispensa de processo de licitação, via chamada pública, desde que os preços fossem "compatíveis com os de mercado" (BONDUKI, 2017, p. 60).

Convém ressaltar a dualidade que o PNAE apresenta, pois, por um lado o programa permite um processo de enraizamento do PNAE nas regiões onde ele é executado, favorecendo a compra no próprio município. No entanto, por outro, o PNAE é:

\begin{abstract}
"provavelmente a mais forte intervenção federal na forma como os estados e municípios devem executar o programa, com a determinação de um perfil de fornecedor específico (os agricultores familiares) e ainda uma série de priorizações no interior deste grupo (assentados, quilombolas, grupos formais, etc.)" (BONDUKI, 2017, p. 59).
\end{abstract}

Essa dualidade aponta o aspecto "de-cima-para-baixo" que a política apresenta, demonstrando que existe uma espécie de imposição para que os agricultores se mantenham no Programa.

Para identificar o produtor como agricultor familiar, o Programa exige que este apresente a Declaração de Aptidão ao Pronaf (DAP). A DAP é um documento criado no âmbito do MDA (atualmente Secretaria Especial de Agricultura Familiar e do Desenvolvimento Agrário - SEAD) e emitido pelas entidades públicas de Assistência Técnica e Extensão Rural (ATER) gratuitamente. Funcionando como o documento identificador de agricultor familiar, a DAP é utilizada para acesso a políticas públicas além do PNAE, como o Minha Casa Minha Vida e outros. Para que seja realizada a compra de produtos comercializados via cooperativas de agricultura familiar, a organização deve possuir um DAP para Pessoa Jurídica, comprovando que sua composição seja de minimamente $70 \%$ de agricultores familiares. Conforme ressalta Bonduki (2017, p. 62), tal exigência, que foi “incluída na Resolução 38 de julho de 2009, fez decolar o número de DAPs Jurídicas emitidas nos anos seguintes, indicando o interesse de cooperativas e associações em fornecer para o PNAE".

O sistema de prioridades para aquisição de produtos ficou melhor esclarecido pelas resoluções 26/2013 e 4/2015, como explica Bonduki (2017, p. 61):

Priorizam-se os grupos mais locais, ou seja, em primeiro lugar do município, do território de identidade ou cidadania, do estado e, por fim, de outros estados. 
Se houver mais de um grupo do mesmo nível territorial, priorizam-se os grupos que tenham ao menos $50 \%$ mais 1 agricultor que sejam de 'categorias' específicas (assentamentos da reforma agrária, comunidades indígenas ou quilombolas, sem prioridade entre eles). Não havendo estes grupos, priorizamse os projetos de organizações com DAP Jurídica (chamados "Grupos Formais") sobre aqueles de grupos não organizados em uma cooperativa ou associação (portadores apenas da DAP Física, ou grupos informais). Nos dois casos acima, há ainda a previsão de o desempate ocorrer pela maior porcentagem de fornecedores pertencentes ao grupo preferencial (ou seja, maior percentual de assentados no projeto, ou maior percentual de agricultores familiares na cooperativa). Persistindo o empate, incluiu-se a prioridade para produtos orgânicos.

Participam do PNAE a totalidade dos estados, grande maioria dos municípios e o Distrito Federal. De acordo com Bonduki (2017), o orçamento do programa gira em torno de $\mathrm{R} \$ 4,15$ bilhões. O repasse do recurso é feito diretamente aos estados e municípios, em acordo ao Censo Escolar, e o valor por dia letivo para cada aluno é definido conforme a modalidade de ensino, sendo: $\mathrm{R} \$ 1,07$ para creches, $\mathrm{R} \$ 0,53$ para pré-escola, $\mathrm{R} \$ 0,64$ para escolas indígenas e quilombolas, $R \$ 0,36$ para ensino fundamental e médio, $R \$ 0,32$ para educação de jovens e adultos, $\mathrm{R}$ \$ 1,07 para ensino integral, $\mathrm{R}$ \$ 2,00 para programa de fomento às escolas de ensino médio em tempo integral e $\mathrm{R} \$ 0,53$ para alunos que frequentam o atendimento educacional especializado no contraturno (BRASIL, [s.d.]).

O órgão regulamentador do PNAE é o Conselho deliberativo do FNDE, presidido pelo Ministro da Educação. O conselho regulamenta as leis federais que competem ao FNDE, define os valores per capta, os instrumentos de compra dos produtos da agricultura familiar com dispensa de licitação e definem os prazos e formato da prestação de contas (BONDUKI, 2017). Compete ainda ao FNDE, definir quais gêneros alimentícios podem ou não ser comprados com os recursos.

A Tabela 4 aponta os valores referentes às aquisições no PNAE, entre os anos 2011 a 2014. Convem ressaltar que até 2014, conforme os dados, ainda não tinha sido atingido o mínimo determinado pelo Lei $\mathrm{N}^{\circ} 11.947 / 2009$. 
Tabela 4 - Valores referentes a compra da agricultura familiar no PNAE (total de 4992 municípios).

\begin{tabular}{lcccc}
\hline & $\underline{\mathbf{2 0 1 1}}$ & $\underline{\mathbf{2 0 1 2}}$ & $\underline{\mathbf{2 0 1 3}}$ & $\underline{\mathbf{2 0 1 4}}$ \\
\hline Recursos transferidos pelo FNDE (em R\$1000,00) & 1.812 .488 & 2.050 .066 & 2.289 .241 & 2.189 .470 \\
\hline $\begin{array}{l}\text { Recursos utilizados na compra da agricultura } \\
\text { familiar (em R\$1000,00) }\end{array}$ & 190.670 & 283.797 & 369.276 & 496.299 \\
\hline Percentual do total repassado & $10,5 \%$ & $13,8 \%$ & $16,1 \%$ & $22,7 \%$ \\
\hline Média dos percentuais de cada município & $15,8 \%$ & $18,7 \%$ & $17,1 \%$ & $24,7 \%$ \\
\hline
\end{tabular}

Fonte: Bonduki (2017).

O acompanhamento e fiscalização do PNAE é feito pela sociedade, por meio dos Conselhos de Alimentação Escolar (CAE), pelo FNDE, pelo Tribunal de Contas da União (TCU), pela Controladoria Geral da União (CGU) e pelo Ministério Público (BRASIL, [s.d.]).

Dada a relevância do PNAE como o maior programa sul-americano de alimentação e nutrição escolar, foram firmados acordos internacionais de cooperação durante os governos Lula e Dilma, com vistas a fornecer apoio ao desenvolvimento em outros países (SABOURIN, 2017). Tendo um investimento de $\mathrm{R} \$ 3,8$ bilhões e $\mathrm{R} \$ 3,5$ bilhões pagos nos anos de 2015 e 2016, respectivamente, o Programa já perpassou por diversos mandatos. Sendo assim, o programa vem sendo executado desde Getúlio Vargas até o mandato do presidente interino Michel Temer (MATTOS, 2017).

\section{Programa Nacional de Produção e Uso do Biodiesel - PNPB}

O sistema de transporte brasileiro é responsável por grandes preocupações para o país. Esse setor é um dos responsáveis pela maior emissão de gás carbônico na atmosfera, provocando problemas relativos ao aquecimento do planeta. Além dos problemas ambientais gerados pelos combustíveis fósseis, o petróleo vem sofrendo mudanças sequenciais em seu valor. Diante disso, os biocombustíveis ganharam relevante atenção mundial, como alternativa a matriz energética atual, principalmente por conta da disseminação do termo desenvolvimento sustentável. O biocombustível surge como uma promissora alternativa pois remete à ideia do uso de produtos energéticos limpos e sustentáveis. Um dos casos de sucesso do uso de biocombustíveis é o Brasil, considerado um dos mais eficientes na produção desse produto, devido ao sistema de produção de cana-de-açúcar a baixo custo (MATTEI, 2010).

O Programa Nacional de Produção e Uso do Biodiesel (PNPB) foi criado em 2004 e desde então conquistou avanços com relação à "inclusão social, geração de emprego e 
distribuição de renda entre agricultores familiares produtores de matéria prima" (BRASIL, [s.d.], p. 3). O PNPB nasceu como uma política direcionada à introdução de um novo combustível de fontes renováveis, priorizando a inclusão da agricultura familiar na compra dos produtos (PIRES, 2015).

Esse programa interministerial objetiva implantar a cadeia de produção e uso do biodiesel no Brasil, focando na competitividade, qualidade do biocombustível produzido, na garantia de segurança de seu suprimento, na diversificação das matérias primas e potencialidades regionais para produção. O programa é conduzido por uma Comissão Executiva Interministerial (CEIB) e coordenado pelo Ministério de Minas e Energia (MME) e integrado por alguns ministérios membros da CEIB e órgãos como o Banco Nacional de Desenvolvimento Econômico e Social (BNDES), Agência Nacional do Petróleo, Gás Natural e Biocombustíveis (ANP), Petrobras e Embrapa. As principais diretrizes do programa são:

\footnotetext{
implantar um programa sustentável, promovendo inclusão social através da geração de renda e emprego;

garantir preços competitivos, qualidade e suprimento;

produzir o biodiesel a partir de diferentes fontes oleaginosas, fortalecendo as potencialidades regionais para a produção de matéria prima (BRASIL, [s.d.], p. 7).
}

A energia gerada pelo biodiesel é chamada de "energia renovável” pois sua produção pode ser feita a partir de gorduras animais ou de óleos vegetais. Para isso podem ser utilizadas diversas espécies vegetais como mamona, dendê, girassol, canola, gergelim, soja e outras. O biodiesel pode substituir total ou parcialmente o óleo diesel de petróleo em motores automotivos (caminhões, tratores, camionetas, automóveis, etc.) ou estacionários (geradores de eletricidade) (BRASIL, [s.d.]).

Ao adquirir a matéria prima de agricultores familiares, os produtores de biodiesel promovem a inclusão social e desenvolvimento regional, por conta da geração de trabalho e renda. Tais produtores recebem o Selo Combustível Social, concedido pela Secretaria Especial de Agricultura Familiar e do Desenvolvimento Agrário (SEAD). São algumas as vantagens e condições especiais de se ter o Selo Combustível Social, sendo elas:

Diferenciação/isenção nos tributos PIS/PASEP e COFINS;

Participação assegurada de $80 \%$ do biodiesel negociado nos leilões públicos da Agência Nacional do Petróleo, Gás Natural e Biocombustíveis (ANP); 
Acesso às melhores condições de financiamento junto aos bancos que operam o Programa (ou outras instituições financeiras que possuam condições especiais de financiamento para projetos);

Possibilidade de uso do Selo Combustível Social para promover sua imagem no mercado (BRASIL, [s.d.], p. 9).

As regiões que possuem as maiores participações nas aquisições da agricultura familiar no PNPB são o Sul e o Centro Oeste. A região Sul se destaca pelo grande número de estabelecimentos de agricultura familiar, maior capacidade de organização em cooperativas "que aumenta a atratividade para a indústria compradora de matérias primas e a predominância regional da oleaginosa soja" (BRASIL, [s.d.], p. 13). A região Centro Oeste, por outro lado, se destaca pela predominância da oleaginosa soja.

O ineditismo do modelo de inclusão social do PNPB se apresenta pela parceria entre os agricultores familiares e a indústria. Como alguns desses agricultores nunca participaram de uma cadeia agroindustrial exigente, os primeiros anos de implantação do programa exigiram que os agricultores passassem por um período de transição. Desse modo, foi necessário "um trabalho estrutural de reforço e incentivo à pesquisa e difusão de tecnologias para oleaginosas com potencial para a região, qualificação dos agentes de assistência e capacitação técnica, programas de correção e preparo de solo, incentivos à organização produtiva, entre outros" (BRASIL, [s.d.], p. 22). "O biodiesel é mais uma forma de incentivar e fortalecer o cooperativismo na agricultura familiar. As empresas com Selo Combustível Social podem comprar diretamente dos agricultores familiares ou de suas cooperativas agropecuárias” (BRASIL, [s.d.], p. 32).

Como a capacidade de organização ainda se revela um desafio para os agricultores familiares, as iniciativas de formação de cooperativas de produção agrícola são essenciais para o PNPB e outros programas que adquiram produtos da agricultura familiar. Isso é explicado pois a formação de cooperativas e o fortalecimento das que já existem permitem "uma participação mais qualificada e sustentável dos agricultores familiares no PNPB, ajudando a superar os tradicionais gargalos agrícolas, mercadológicos e gerenciais destes atores" (BRASIL, [s.d.], p. 35). Isso porque organizados em cooperativas os agricultores familiares alcançam "melhores resultados e maiores vantagens na escala de produção, redução de custos, logística, facilidade de acesso a insumos e tecnologias de produção e maior poder de barganha ao negociar os contratos com empresas produtoras de biodiesel, entre outros" (BRASIL, [s.d.], p. 35). 
As aquisições (em milhões $\mathrm{R} \$$ ) da agricultura familiar para produção do biodiesel cresceram consideravelmente a partir de 2010, porém, embora a relevância social e ambiental que o programa acarreta, a partir de 2013 é possível observar uma pequena queda nas aquisições, conforme observado na Figura 5.

Figura 5 - Evolução de valores das aquisições da agricultura familiar para produção do biodiesel, em milhões de reais.

\section{AQUISIÇÕES DA AGRICULTURA FAMILIAR}

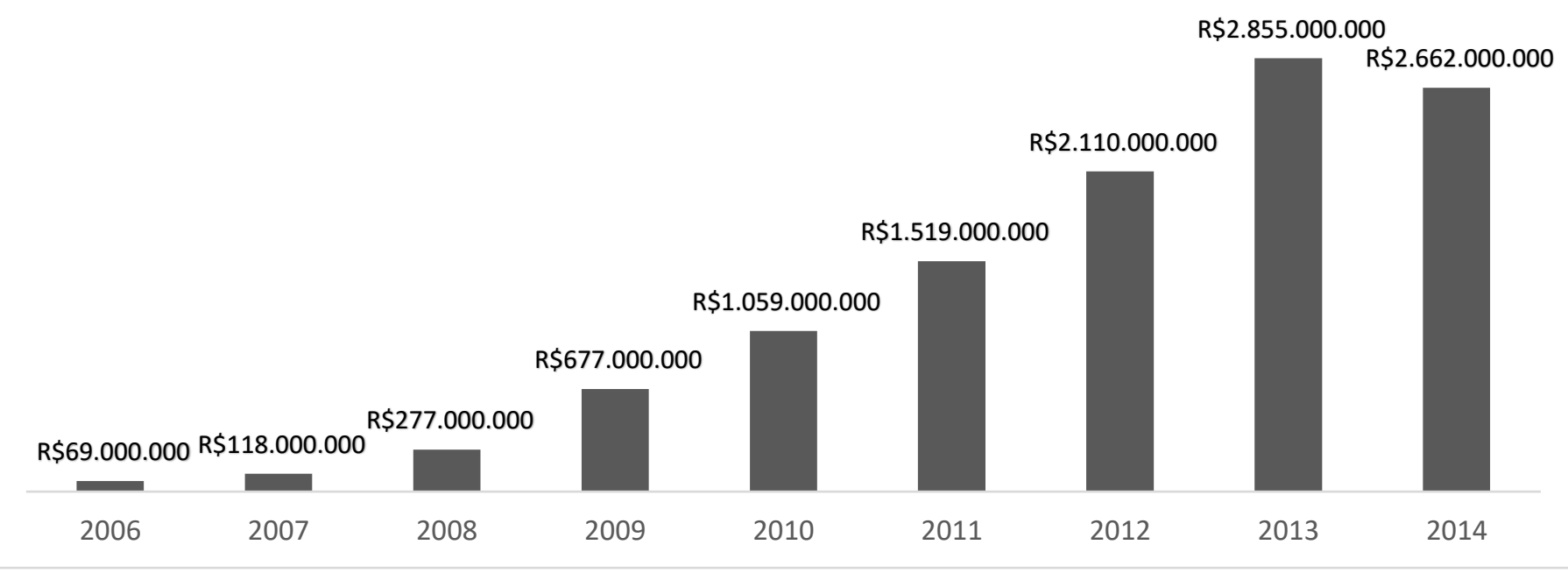

Fonte: Brasil (2017c).

O crescimento na produção do biodiesel, com amplo incentivo por parte do governo, deu-se entre 2005 a 2013, porém, isso está atrelado mais à obrigatoriedade imposta pelas leis $\mathrm{n}^{\circ} 11.097$, de 13 de janeiro de 2005 e a $\mathrm{n}^{\circ} 11.116$, de 18 de maio de 2005, que dispõem sobre a introdução do biodiesel na matriz energética brasileira e também sobre as reduções das contribuições tributárias (SILVA et al., 2015).

Mesmo com o incentivo de aquisição de produtos oriundos da agricultura familiar, no ano de 2014, conforme lei $\mathrm{n}^{\circ} 13.033$ (BRASIL, 2014c), de 24 de setembro de 2014, foi revogado o Art. $2^{\circ}$ da lei $\mathrm{n}^{\circ} 11.097$ de janeiro de 2005 que priorizava a aquisição de produtos da agricultura familiar, dentre outras:

\footnotetext{
$\S 4^{\circ} \mathrm{O}$ biodiesel necessário ao atendimento dos percentuais mencionados no caput deste artigo terá que ser processado, preferencialmente, a partir de matérias-primas produzidas por agricultor familiar, inclusive as resultantes de atividade extrativista (BRASIL, 2005).
}

A revogação do referido artigo configura-se como uma atitude displicente aos interesses e fomento da agricultura familiar. Tal ação é entendida como contrária à 
expectativa que o governo federal nutria em alavancar a participação da agricultura familiar em sua cadeia produtiva, por meio do PNPB (PIRES, 2015). 


\section{Breves considerações}

A construção do referencial teórico neste capítulo permitiu compreender a definição de políticas públicas sob alguns olhares e ainda, explicitar formas de análise das políticas públicas por meio de duas teorias: a teoria do ciclo de políticas públicas e a teoria dos fluxos múltiplos.

Após a compreensão das teorias acima citadas, foi possível apresentar um breve histórico das políticas públicas de $3^{\text {a }}$ geração acessadas pelas cooperativas de agricultura familiar atendidas pelo Mais Gestão. Tal referencial propiciou a identificação das questões pelas quais a agricultura familiar vêm passando no Brasil.

Constatando a fragilidade dos agricultores familiares perante as opções de desenvolvimento até então expostas no país, algumas instituições foram fundamentais para fomentar a ascensão dos agricultores familiares, como o extinto Ministério do Desenvolvimento Agrário (MDA) e a Secretaria de Agricultura Familiar (SAF). O caminho para o processo de reconhecimento da classe "agricultor familiar" que engloba inúmeros segmentos, como quilombolas, pescadores, etc., foi longo e árduo. As principais mudanças ocorreram após a criação do Pronaf, no mandato do ex-presidente Fernando Henrique Cardoso e durante o primeiro mandato do ex-presidente Luiz Inácio Lula da Silva, com a criação de mercados institucionais.

Para além da produção, outra dificuldade surge para os agricultores perante os mercados institucionais. Os agricultores familiares agora precisam estar organizados e planejar suas produções para melhor atender e se manter nos mercados. Diante disso, é nítida a necessidade de o governo criar medidas para auxiliar esses agricultores. 


\section{O PROGRAMA MAIS GESTÃO E O CICLO DE POLÍTICAS PÚBLICAS}

\section{Introdução}

Para melhor compreender o Programa Mais Gestão e sua descontinuidade, um dos objetivos deste trabalho é refletir sobre o "ciclo de vida" do Programa a partir da teoria do ciclo de políticas públicas (police cycle) (KINGDON, 2006a). A escolha dessa teoria se justifica pela facilidade de análise a partir da perspectiva do ciclo de política pública. Convém ressaltar, no entanto, que o ciclo não é linear e por vezes alguma fase pode se sobrepor a outra.

A partir da base teórica abordada no capítulo 2, neste capítulo foi desenvolvido o ciclo de vida do Programa Mais Gestão. Pressupõe-se que o ciclo de vida do PMG é capaz de subsidiar a compreensão do mesmo e, além disso, iniciar a discussão quanto ao fim do Mais Gestão, permitindo verificar se a avaliação teve papel preponderante em sua descontinuidade.

Desse modo, são abordadas as seis fases do ciclo de políticas públicas neste capítulo: identificação do problema; agenda; formulação de alternativas; tomada de decisão; implementação do Programa com exposição de características das cooperativas atendidas pelo PMG e por fim a avaliação. 


\section{O Programa Mais Gestão}

Em particular durante o primeiro mandato do ex-presidente Lula (2003-2006), o Brasil envidou esforços para que os agricultores familiares fossem reconhecidos e promoveu a criação de diversos programas para que eles pudessem ampliar suas vendas. Mesmo com uma demanta crescente, os agricultores se depararam com dificuldades para suprir tal demanda. Essas dificuldades estavam relacionadas principalemente no que concerne à organização dos agricultores familiares.

A organização dos agricultores foi considerada um problema, pois, para ter acesso aos programas institucionais era necessário atender a alguns requisitos, como, por exemplo, apresentar a DAP. Desse modo, como apontaram Fornazier e Belik (2011), cabe um reparo no que concerne à organização dos produtores para atender e responder à demanda gerada e também obter ganhos.

Diante das exigências por institucionalização e certificação das atividades da agricultura familiar, o MDA decidiu incentivar os agricultores familiares a organizar sua base produtiva e também qualificar a gestão das organizações cooperativas para que estes pudessem acessar os mercados institucionais, em particular o Programa de Aquisição de Alimentos (PAA) e o Programa Nacional de Alimentação Escolar (PNAE) (SOUSA et al., 2014). Assim, para fortalecer esses mercados e promover o acesso dos agricultores aos mercados institucionais, foi criado em 2012, no âmbito do MDA, o Programa Mais Gestão. A estratégia do programa para o fortalecimento da agricultura familiar se dá por meio do fornecimento de Assistência Técnica e Extensão Rural (ATER) coletiva para as cooperativas que possuem a Declaração de Aptidão ao Pronaf (DAP) de Pessoa Jurídica.

Os serviços de ATER desde a década de 1970 têm sido estruturantes para o avanço dos agricultores (AVILA et al., 2015). Esses serviços passaram a ter ainda mais relevância com a chamada Nova Lei de ATER, instituída pela Lei ${ }^{\circ} 12.188$ de 11 de janeiro de 2010. Essa Lei propõe uma nova forma de atuação para as equipes de ATER e também provoca alterações na organização desses serviços. Duas alterações são as mais significativas: a primeira está relacionada à alteração da Lei ${ }^{\circ} 8.666$ de 21 de junho de 1993, que provoca a dispensa de processo licitatório para a contratação de equipes de ATER, e também a alteração do instrumento jurídico, em que a partir de então nas 
chamadas públicas são estabelecidos os contratos, ao invés de convênios $^{6}$ (AVILA et al., 2015).

De modo geral, são diversos os serviços de ATER oferecidos no país. A oferta de ATER se dá por meio de organizações públicas, privadas, ONGs e outras. Durante os anos de 2013 a 2016, houve um considerável aumento no número de atendimentos de ATER, conforme exposto na

Figura 6:

Figura 6 - Evolução do número de atendimentos de ATER no Brasil

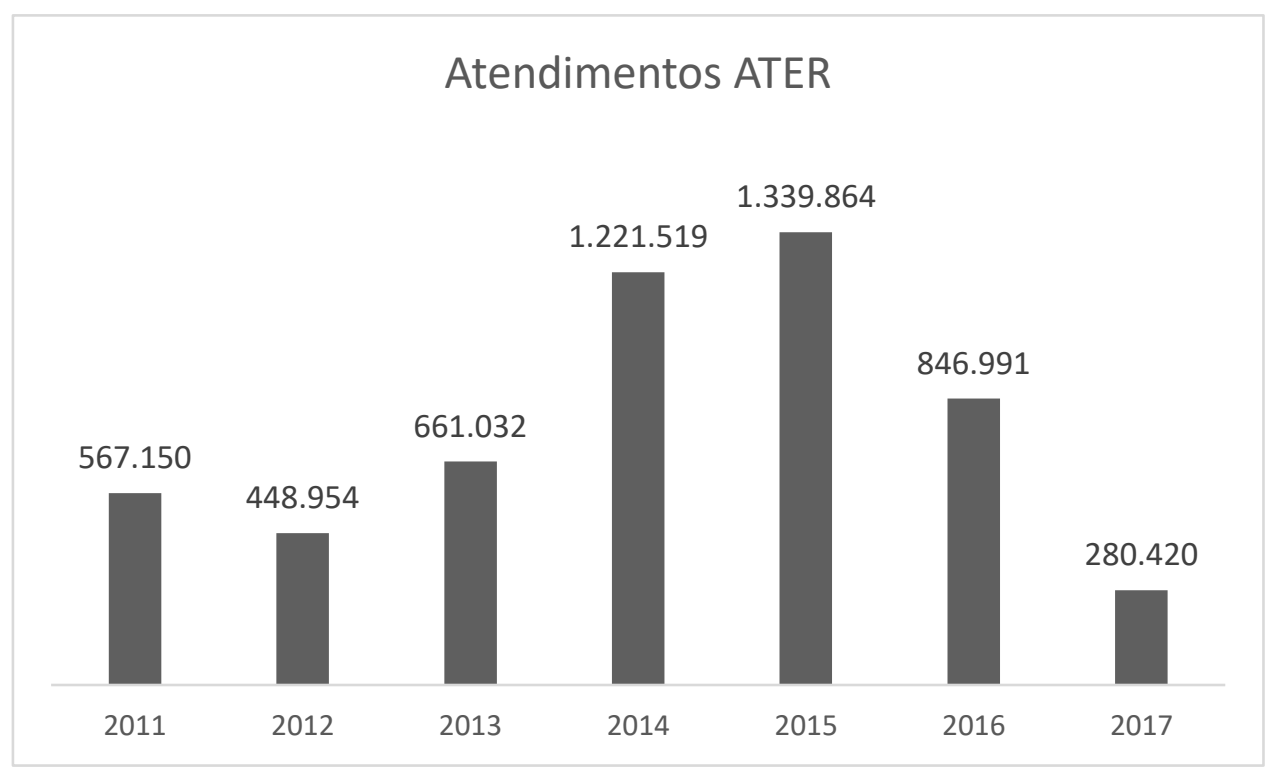

Fonte: Painel de Politicas - SEAD (BRASIL, 2017a).

Desse modo, refletindo as inovações da Nova Lei de ATER, o Programa Mais Gestão "desloca o eixo da assistência técnica do enfoque individual para o coletivo de organizações de produtores (cooperativas) e amplia o olhar anteriormente dedicado à produção, para a gestão e comercialização" (AVILA et al., 2015, p. 3).

Para o oferecimento da ATER coletiva, o Programa lançou chamadas públicas que dispensam licitação visando contratar equipes de ATER para promover o fortalecimento

\footnotetext{
${ }^{6}$ A Lei ${ }^{\circ} 12.188$, de 11 de janeiro de 2010, estabeleceu como mecanismo de contratação de equipes de ATER as chamadas públicas, que definem o objeto a ser contratado, a qualificação e a quantificação do público beneficiário, área geográfica de prestação dos serviços, prazo para execução, valores para contratação, qualificação técnica exigida e critérios para seleção.

A referida lei define ainda que os contratos são acompanhados e fiscalizados pela Lei $\mathrm{N}^{\circ} 8.666$, de 21 de junho de 1993 que define que sua execução deve ser acompanhada e fiscalizada por um representante da Administração especialmente designado.
} 
e a inserção de cooperativas da agricultura familiar (detentoras de DAP Jurídica) nos mercados institucionais. Esse fortalecimento se deu por meio de atendimentos às cooperativas para execução dasa etapas do PMG.

Assim, o PMG, concebido para preencher a lacuna de conhecimento e capacidade técnica em cooperativas da agricultura familiar, é definido como uma política que "visa a resolução de problemas técnico-gerenciais e tecnológicos dirigidos a empreendimentos da agricultura familiar, visando incrementar a competitividade e promoção da cultura empresarial em pequenos e médios produtores rurais" (SOUSA et al., 2014, p. 3). A metodologia do programa busca, por meio das equipes de ATER, oferecer ferramentas de “apoio à decisão, visando o aprimoramento das diferentes áreas funcionais (organizacional, industrial, comercial e financeira)" das cooperativas (AVILA et al., 2015, p. 4). Para melhor compreender o PMG, busca-se identificar cada etapa do ciclo de políticas públicas (police cycle):

\section{Problema}

A demanda por produtos da agricultura familiar vem constantemente sendo ampliada, principalmente atrelada ao modelo de compras públicas para a promoção do desenvolvimento local. Essa demanda teve início principalmente no ano de 2003, com a criação do PAA e posteriormente com a promulgação da Lei $\mathrm{N}^{\circ} 11.947 / 2006$. A Lei estabelece o mínimo de $30 \%$ para compras da agricultura f amiliar no âmbito do PNAE (BRASIL, 2009), que é caracterizado como um dos programas mais relevantes para a agricultura familiar (BRASIL, 2014a).

A visão obsoleta de que os agricultores precisavam apenas ter a noção de como produzir foi paulatinamente superada. Atualmente, além de ter as noções de produção agrícola, os agricultores precisam conhecer o consumidor para melhor atendê-lo e precisam também estar qualificados no que se refere a aspectos legais, tributários, fiscais, sanitários, comerciais, ambientais e diversas outras temáticas. Como a ATER originalmente é focada na produção, os agricultores familiares, principalmente as organizações cooperativas, carecem de uma assistência diferenciada que contemple os aspectos supracitados (AVILA et al., 2015). Compreender os entraves e identificar a melhor maneira de organizar a produção é fundamental para que os agricultores possam ofertar produtos para os mercados institucionais. 
Mesmo com o advento da Nova Lei de ATER (Lei $\mathrm{n}^{\circ}$ 12.188/2010) aliada à ampliação de mercados institucionais e a crescente oferta de crédito para os agricultores familiares, inúmeras são as dificuldades enfrentadas por eles. Uma dessas entraves é a comercialização, ou seja, a etapa "depois da porteira", que carece de um conhecimento maior das técnicas e estratégias de mercado, associadas, ainda, à necessidade de conhecimento das técnicas de produção (AVILA; CALDAS; ASSAD, 2013).

Conforme exposto pela Tabela 5, são diversas as destinações de produção dos agricultores familiares, tais como feiras e mercados livres, supermercados, atacado, exportação e ainda os mercados institucionais caracterizados como um expressivo e fundamental canal de comercialização.

Tabela 5 - Faturamento (R\$) das cooperativas atendidas pelo Programa Mais Gestão em diferentes mercados.

Faturamento referente a comercialização nos anos de 2010, 2011 e 2012

\begin{tabular}{cccccc}
\hline Ano & $\begin{array}{c}\text { Feiras e } \\
\text { mercados livres }\end{array}$ & Supermercados & Atacado & Exportação & $\begin{array}{c}\text { Mercados } \\
\text { institucionais }\end{array}$ \\
\hline $\mathbf{2 0 1 0}$ & $\mathrm{R} \$ 23.154 .318,00$ & $\mathrm{R} \$ 59.137 .082,00$ & $\mathrm{R} \$ 233.957 .191,00$ & $\mathrm{R} \$ 12.463 .487,00$ & $\mathrm{R} \$ 196.132 .664,00$ \\
\hline $\mathbf{2 0 1 1}$ & $\mathrm{R} \$ 27.569 .980,00$ & $\mathrm{R} \$ 144.930 .629,00$ & $\mathrm{R} \$ 301.620 .566,00$ & $\mathrm{R} \$ 22.416 .377,00$ & $\mathrm{R} \$ 302.292 .185,00$ \\
\hline $\mathbf{2 0 1 2}$ & $\mathrm{R} \$ 32.524 .156,00$ & $\mathrm{R} \$ 66.001 .708,00$ & $\mathrm{R} \$ 333.431 .468,00$ & $\mathrm{R} \$ 38.136 .180,00$ & $\mathrm{R} \$ 258.397 .780,00$ \\
\hline
\end{tabular}

Fonte: Secretaria Especial de Agricultura Familiar e do Desenvolvimento Agrário (BRASIL, 2016a).

A tabela acima exposta reflete os dois tipos de mercado que as cooperativas comercializam seus produtos: o mercado privado e o mercado institucional. A destinação de produtos para o mercado institucional coompreende basicamente os programas PAA, PNAE e PNPB. Com relação ao mercado privado, é possível observar uma ascenção do faturamento, com exceção dos supermercados, que apresentou uma queda considerável do valor, do ano de 2011 para 2012, mesmo que superior ao de 2010. Outra queda no faturamento é observada também do ano de 2010 para o ano de 2011 nos mercados institucionais, mesmo que o número de organizações que tenham fornecido as informações seja maior (138 cooperativas em 2010 e 201 cooperativas em 2011).

Uma rápida comparação entre as duas tabelas permite observar que o faturamento das cooperativas no que se refere a comercialização para os mercados privados é superior à comercialização para os mercados institucionais, pois as cooperativas podem comercializar para feiras e mercados livres, supermercados, atacado e também para exportação. Além disso, os valores de faturamento para atacado e mercados institucionais 
se aproximam consideravelmente. Esses valores podem indicar dificuldade na venda para os mercados institucionais, em detrimento aos mercados privados.

Nesse aspecto, os estudos de Sousa (2015) indicam um feedback sobre o PNAE pelo monitoramento dessa política. Esse monitoramento foi observado pelo Projeto NUTRE SP - Análise da Inclusão da Agricultura Familiar na Alimentação Escolar no Estado de São Paulo, que aponta que:

\begin{abstract}
As 100 maiores prefeituras $(1,7 \%$ do total) recebem cerca de $30 \%$ dos recursos repassados aos municípios. Dado seu elevado grau de urbanização, no entanto, o número de agricultores familiares locais é significativamente menor. Assim, tais regiões apresentam a condição específica de, por um lado, disporem de um mercado institucional de peso e, por outro, não comportarem quantidade compatível de agricultores familiares (AMELIA et al., 2012, p. 7).
\end{abstract}

O PNAE "representa um grande desafio para as organizações econômicas da agricultura familiar, uma vez que está concentrado nas regiões metropolitanas e grandes cidades, desafiando a capacidade logística de organização e entrega de produtos in natura e beneficiados" (BRASIL, 2014a, p. 1). Além disso, são muitas as exigências do mercado, tais como: "padronização de produtos, volume de comercialização, atenção a exigências de caráter ambiental, atenção à concorrência, certificação da produção, controle de qualidade dos produtos e comprovação de segurança dos alimentos dentre outras" (SÃO JOSÉ; PEREIRA; OLIVEIRA, 2017, p. 5).

Uma das alternativas para sanar esses desafios de gestão é fomentar os processos de ATER para qualificar e fortalecer as cooperativas da agricultura familiar, visto que elas ainda apresentam "fragilidades do ponto de vista gerencial, insuficiente apropriação de ferramentas de gestão, pouca capacidade de planejamento de médio e longo prazos e baixos investimentos em modernização de seus processos" (BRASIL, 2014a, p. 1-2). O reconhecimento da lacuna no que se refere a gestão das cooperativas de agricultura familiar foi um dos problemas que propiciaram a gênese do Programa Mais Gestão (AVILA; CALDAS; ASSAD, 2013).

As dificuldades e a falta de gestão apresentadas pelas organizações brasileiras podem estar relacionadas à idade das mesmas. Pela Figura 7, nota-se que as cooperativas são jovens organizações, dependentes e demandantes de políticas públicas para se estruturarem (BRASIL, 2016a). 
Figura 7 - Faixa de idade das cooperativas atendidas pelo Programa Mais Gestão: até 3 anos; de 4 a 10 anos; de 11 a 25 anos; de 26 a 50 anos e acima de 51 anos.

\section{Faixa de idade das cooperativas atendidas pelo Programa Mais Gestão}

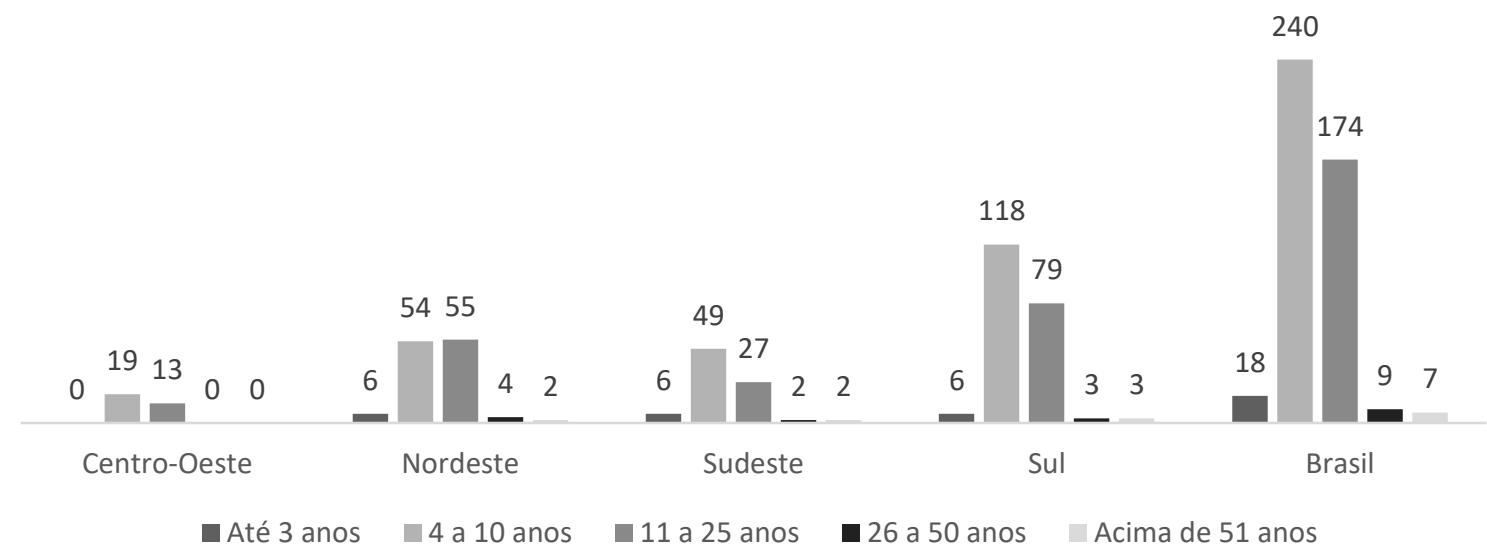

Fonte: Secretaria Especial de Agricultura Familiar e do Desenvolvimento Agrário (BRASIL, 2016a).

Conforme indicado pela figura acima, a maioria das cooperativas (com exceção da região Nordeste) apresentam uma idade estimada de 4 a 10 anos de idade. Logo em seguida, a segunda faixa de idade que apresenta um maior número de organizações cooperativas gira em torno de 11 a 25 anos. Desse modo, apenas 4\% das cooperativas entrevistadas durante a execução do Programa Mais Gestão, possuem idade superior a 26 anos, o que pode indicar uma organização deficiente por parte das organizações.

É importante observar que os dados são oriundos de entrevistas realizadas entre os anos de 2012 a 2014, pelos agentes de ATER contratados para execução do Mais Gestão. Desse modo, é possivel inferir que as cooperativas que responderam no ano de 2012 e possuem até 10 anos, foram criadas em meados de 2002, período em que as políticas públicas para a agricultura familiar começaram a ser criadas e fortalecidas.

Compreendeu-se, portanto, que os agricultores familiares possuíam dificuldades em acessar ao PNAE, em particular pela carência de gestão e organização das cooperativas. Com a identificação da carência em gestão e organização das cooperativas e o reconhecimento da agricultura familiar, o MDA intensificou ainda mais o apoio às organizações da agricultura familiar, investindo no tripé gestão-produto-mercados.

Dessa maneira, o fluxo de problemas que deu origem ao PMG está relacionado às dificuldades de acesso ao PNAE. Já que estava dado um enorme mercado por parte do 
governo, corria-se o risco de ele não ser atendido em virtude da complexidade que os agricultores familiares enfrentavam em organizar sua produção (BRASIL, 2016b; SOUSA, 2015)

\section{Agenda}

Como a Lei que institucionalizou o PNAE não vinha sendo atendida, era claro o reconhecimento de que os agricultores familiares não estavam conseguindo atender às demandas dos mercados institucionais. Nesse sentido, foi consentimento de que "as cooperativas, organizações econômicas por natureza (...) poderiam também se constituir em intermediários fortes para os agricultores familiares na inserção aos mercados" (SOUSA et al., 2014, p. 2). No entanto, foi observado que as cooperativas também não conseguiam vender seus produtos aos mercados institucionais, de maneira a suprir a demanda, evidenciando que era necessária a criação de ferramentas e serviços para qualificar essas organizações (SOUZA, 2013).

A conjuntura política favorável para a formação de uma agenda para políticas públicas para a agricultura familiar começou a se desdobrar concretamente durante o primeiro mandato do ex-presidente Luiz Inácio Lula da Silva (SOUSA, 2015).

Com a instituição da Política Nacional de Assistência Técnica e Extensão Rural (PNATER) e a Nova Lei de ATER, Lei $\mathrm{n}^{\circ}$ 12.188/2010, abre-se a oportunidade de implementação de políticas públicas no âmbito da ATER e também favorecendo a criação de políticas para as cooperativas de agricultura familiar (AVILA et al., 2015). Nesse período o MDA pôde envidar esforços para "intensificar apoio aos empreendimentos da agricultura familiar, com vistas a facilitar o acesso aos mercados e a créditos" (SOUZA, 2013).

Além do momento político favorável, é possível perceber o quão os mercados institucionais são fundamentais para as cooperativas, conforme exposto na Figura 8, que indica a participação dos mercados institucionais no faturamento total. 
Figura 8 - Participação dos mercados institucionais no faturamento total (em \%).

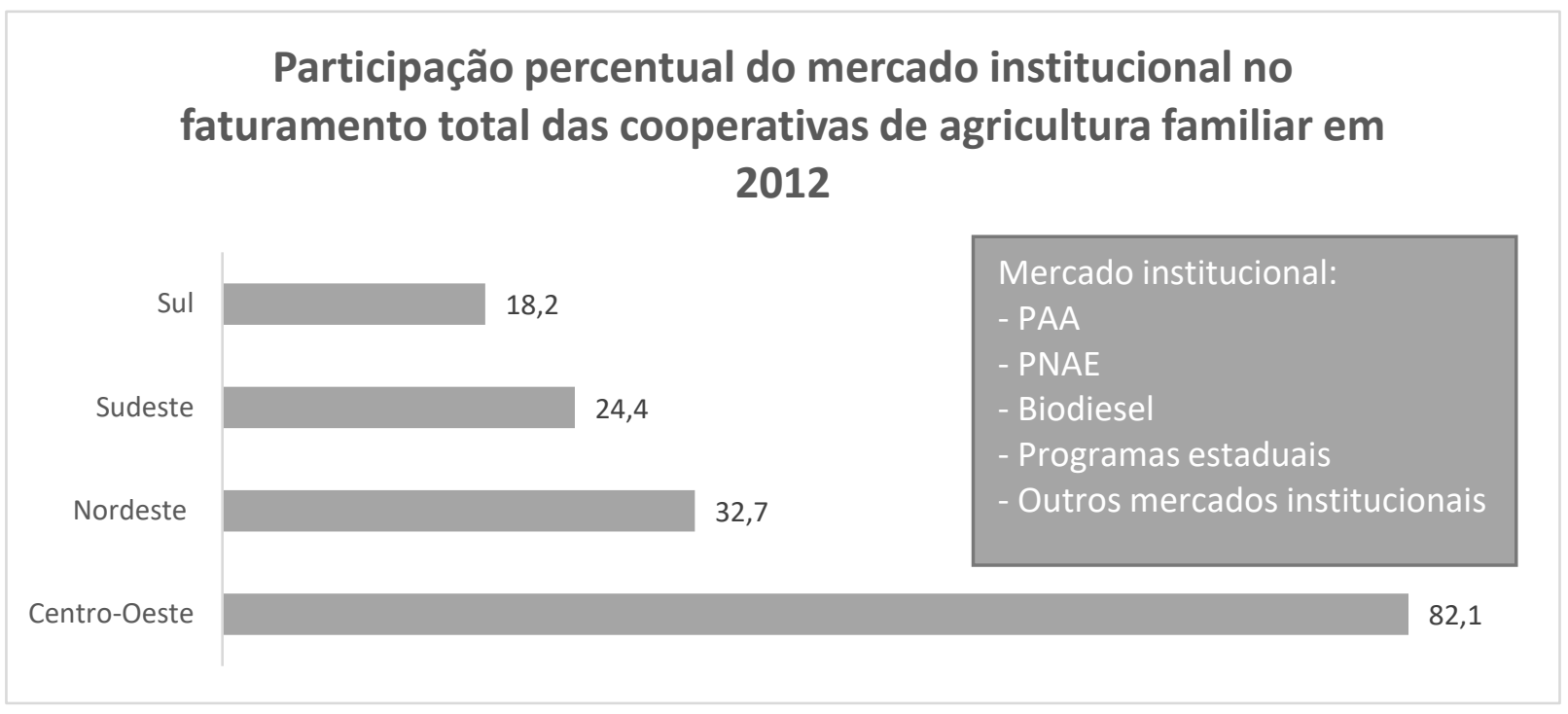

Fonte: Rede de Universidades na Avaliação do Programa Mais Gestão.

Os dados expostos acima indicam o quão relevante os mercados institucionais são para as cooperativas no que se refere ao faturamento total. É possível que na região Centro-Oeste, os mercados institucionais representam mais de $80 \%$ do faturamento total das cooperativas de agricultura familiar.

Enquanto que para a região Centro-Oeste o valor de participação do faturamento nos mercados institucionais é consideravelmente relevante, para as outras regiões há ainda o que aperfeiçoar. As regiões Sul, Sudeste e Nordeste não apresentam nem ao menos $50 \%$ de participação dos mercados institucionais no faturamento total, revelando a necessidade de ampliar tal questão.

\section{Formulação de alternativas}

Mesmo com a percepção do problema, ainda não se tinha clareza de qual solução poderia ser utilizada. Diferentemente de algumas políticas, a solução para sanar o não atendimento das cooperativas aos mercados institucionais já havia sido criada, porém, era necessário que se fizessem adaptações.

A solução encontrada pelo então MDA foi desenvolvida pelo Ministério da Indústria, Comércio Exterior e Serviços (MDIC), a Metodologia PEIEx (Projeto de Extensão Industrial Exportadora), que fora criada para realizar diagnósticos e sanar problemas técnico-gerenciais para micro empreendimentos, com foco na exportação. $\mathrm{O}$ Departamento de Geração de Renda e Agregação de Valor (DEGRAV) percebeu, no ano 
de 2008, que seria necessária a adaptação da metodologia, com foco para as cooperativas de agricultura familiar:

Arnoldo chegou para equipe e falou: olha, eu fui com o secretário participar de uma reunião no MDIC. E o pessoal apresentou pra gente uma ferramenta que eles tem, que se chama PEIEX, e que adaptada a realidade da agricultura familiar pode ser muito útil para nos ajudar a encontrar o caminho (E16, 2015).

A adaptação foi realizada mediante dois convênios, um para o bioma Cerrado, o Projeto APLs do Cerrado firmado com a Casa Verde Cultura e Meio Ambiente (iniciado em julho de 2008), e outro para o bioma Caatinga firmado com o Centro de Apoio a Microempreendedores (CAM) (iniciado em abril de 2009) (convênio MDA 030/2008 e Termo de Parceria (742866/2010). A adaptação, no entanto, não foi fácil, pois, o então MDA e o MDIC não firmaram o Termo de Cooperação Técnica para a transferência de conhecimentos, ferramentas e apoio técnico. Desse modo, a Casa Verde e o CAM iniciaram a adaptação sem o apoio prometido previamente.

\section{A adaptação da metodologia PEIEX}

A adaptação foi realizada sem a transferência da metodologia para o MDA, não ocorreu nenhum tipo de capacitação para as ONGs contratadas, ou mesmo o repasse de documentos, apenas a entrega de uma espécie de caderno com as ideias centrais do PEIEx, conforme apontou uma das entrevistadas:

E aí fomos surpreendidos com a notícia de que o PEIEX tinha sigo engavetado no MDIC, que o Leonardo já não trabalhava mais lá. O Leonardo tinha ido para a APEX e que não havia ambiente político para qualquer articulação que viabilizasse a capacitação da Casa Verde (E6, 2015).

Como o contrato já estava assinado, as duas organizações tiveram de reconstruir a metodologia do MDIC por conta própria. A Casa Verde e o CAM tiveram de prosseguir com a adaptação tanto da metodologia quanto das ferramentas, além de estarem envolvidos nos projetos pilotos. Desse modo, além de realizar a adaptação metodológica, as ONGs tiveram de prestar assistência técnica às cooperativas que estivessem envolvidas nos projetos, conforme complementa uma das envolvidas na adaptação:

A gente não teve muita oportunidade de fazer até uma elaboração teórica do que seria essa gestão. Porque toda concepção teórica do programa a gente sabia que ia receber do MDIC. E aí aconteceu o inesperado, não foi um simples detalhe, é como se eu te vendesse uma grande televisão e dissesse assim ó: tá aqui o controle da televisão, daqui a pouco a pessoa que vai te ensinar a usar, vai chegar. Só que a pessoa não chegou! Mudou o cenário no MDIC, a equipe que trabalhava com os projetos foi toda demitida, algumas pessoas foram pras ATER's. Mas o fato é que aquela parceria que foi desenhada para fazer a 
transferência do PEIEX, ela não aconteceu. A gente não tinha bagagem, não tinha bibliografia (E6, 2015).

Mesmo com todos os entraves, a Casa Verde promoveu uma reflexão sobre o papel que a metodologia poderia potencializar e os objetivos que deveriam ser seguidos. É importante ressaltar que, conforme estudos apontados pela Rede de Universidades na avaliação do Programa Mais Gestão, o MDA não utilizou estruturas importantes desenhadas pela ONG, como a estrutura organizacional do Projeto, que apresentava os seguintes componentes (BRASIL, 2016b):

(1) Conselho gestor: composto da Coordenação da Rede Cerrado +8 Monitores Regionais (MR) + Coordenador do Projeto;

(2) Núcleo operacional central (NOC): composto de 1 Coordenador +1 Monitor + 5 Técnicos extensionistas + 1 Assistente técnico central (ATC);

(3) Cada estado contava em seu Ponto de Apoio Regional (PAR) com 1 Monitor Regional (MR) + 1 Assistente Técnico Regional (ATR).

Um outro aspecto fundamental criado pela ONG foi a tipificação das organizações, ou seja, agrupá-las de acordo com suas características organizacionais ou produtivas. Essa medida facilitaria a atuação das equipes de ATER, promovendo diferentes tipos de didática. No entanto, tal prática não foi utilizada pelo extinto MDA na construção das chamadas públicas. A cronologia da adaptação pode ser compreendida a partir da compilação abaixo: 
Figura 9 - Histórico de adaptação da metodologia PEIEx e contratação das Organizações Não Governamentais - A Casa Verde e Centro de Apoio a Microempreendedores pelo Ministério do Desenvolvimento Agrário.

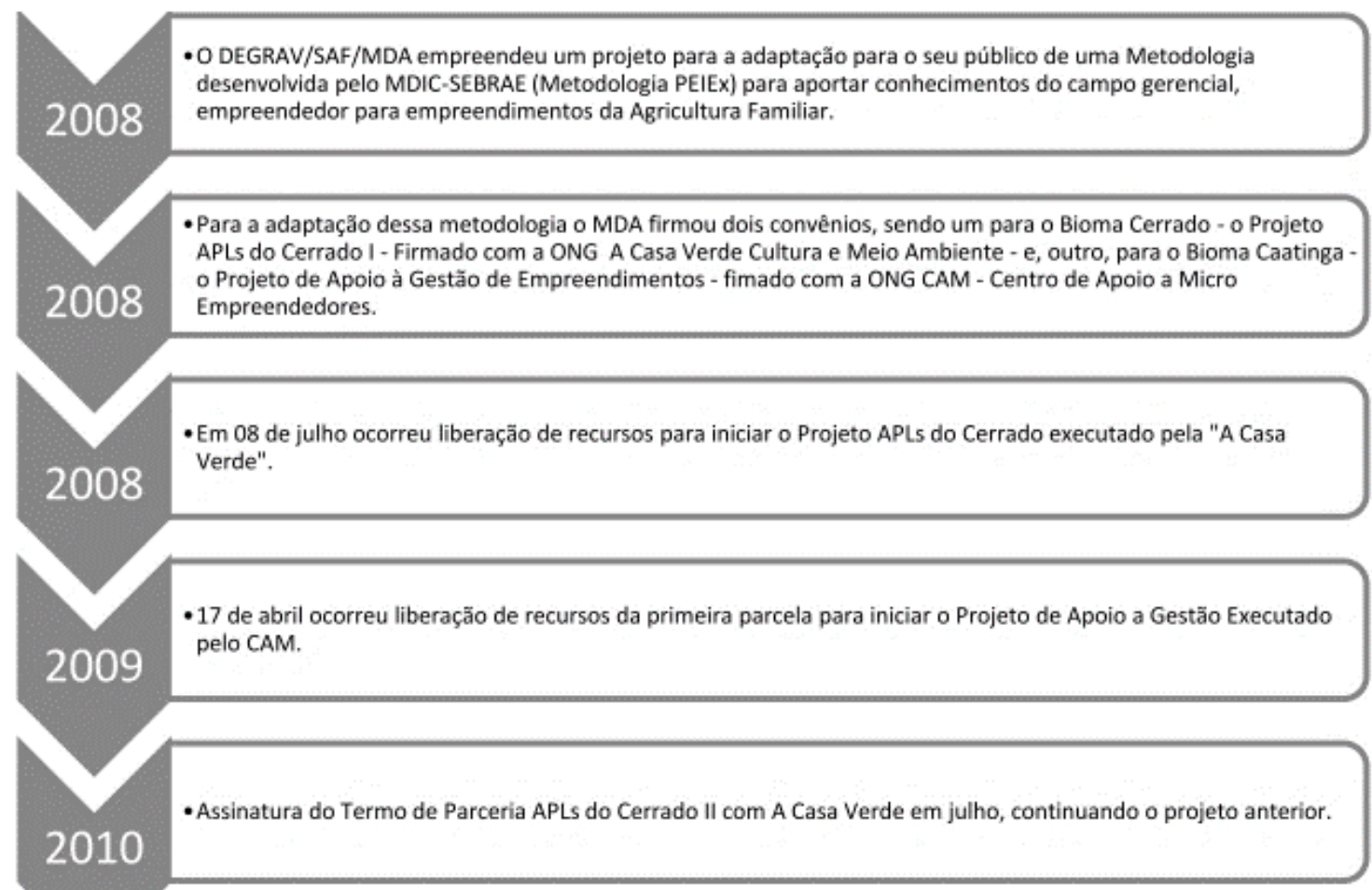

Fonte: Compilação dos dados fornecidos pelo Entrevistado E16 (2015).

Embora tenha sido assinado um Termo de Parceria APLs do Cerrado II com A Casa Verde em julho de 2010, o projeto de adaptação e continuidade foi encerrado a partir de dezembro do mesmo ano, com a paralização das atividades por falta de recursos. $\mathrm{O}$ Convênio, no entanto, só foi encerrado oficialmente em dezembro de 2012 (SOUSA, 2015).

\section{$\underline{\text { Tomada de decisão }}$}

Com o reconhecimento do problema de não atendimento ao PNAE, o MDA encontrou a solução para sanar a carência das organizações cooperativas. Tal solução, previamente criada pelo MDIC, foi adaptada à realidade dos agricultores familiares, e então, no ano de 2012 o MDA pode instituir o Programa Mais Gestão.

A implementação desse programa visava qualificar os sistemas de gestão para garantir o acesso aos mercados institucionais, revelando-se como uma iniciativa fundamental para atender a demanda governamental (SÃO JOSÉ; PEREIRA; OLIVEIRA, 2017). 
A decisão de implementar a política tem alguns aspectos que devem ser levados em conta. O contexto político (limitação de recursos, por exemplo) e a urgência em atender às demandas de mercados institucionais e potencializar novos canais de comercialização, foram os principais influenciadores para que a construção do Programa se desse de forma breve e restrita ao meio governamental, sem tempo para diálogos com a sociedade civil, conforme aponta a Entrevistada E10 (2015):

[...] na construção da Chamada não havia muito tempo para envolver a sociedade civil, pois não tínhamos muito tempo (...), não havia tempo para fazer uma rodada com sociedade civil, senão você não lançaria essa Chamada [Chamada 04] que era muito importante. Tinha-se a consciência de que ela precisaria ser aprimorada e era uma grande oportunidade no contexto daquele ano e, se fosse fazer outras rodadas de conversas, contribuições, perderíamos muito tempo. A gente já tinha algumas definições, que foram pelos próprios projetos que já vinham sendo executados [...]

\section{Implementação}

Para promover o Programa Mais Gestão, o MDA lançou chamadas públicas para que as organizações de ATER contratadas pudesses identificar a realidade da cooperativa, identificar as falhas e sugerir as melhorias. Tais chamadas adotam a metodologia adaptada pela Casa Verde e pelo CAM, uma metodologia

singular e com uma abordagem multidisciplinar que permite a identificação e solução de problemas técnicos gerenciais e tecnológicos, a fim de incrementar a competitividade e promover a cultura de sustentabilidade social e econômica nos empreendimentos da agricultura familiar (BRASIL, 2014a, p. 2).

As chamadas públicas foram elaboradas pelo Departamento de Geração de Renda e Agregação de Valor (DEGRAV) em parceria com o Departamento de Assistência Técnica e Extensão Rural (DATER), ambos vinculados à Secretaria de Agricultura Familiar do MDA. Enquanto o DEGRAV visava apoiar as ações voltadas para a comercialização, produção de biocombustíveis e diversificação econômica, o DATER estava atrelado às políticas públicas de assistência técnica e extensão rural no país.

O PMG concebia assistência técnico gerencial para as cooperativas da agricultura familiar que acessam aos mercados institucionais, com vistas a garantir a qualificação de tais organizações e que o atendimento às exigências e especificidades das chamadas, conforme Matriz Lógica do Programa, elaborada pela Rede de Universidades na Avaliação do Programa Mais Gestão, indicada na Figura 10. 
Figura 10 - Matriz lógica geral do Programa Mais Gestão, destacando os objetivos gerais e específicos, metas e produtos.

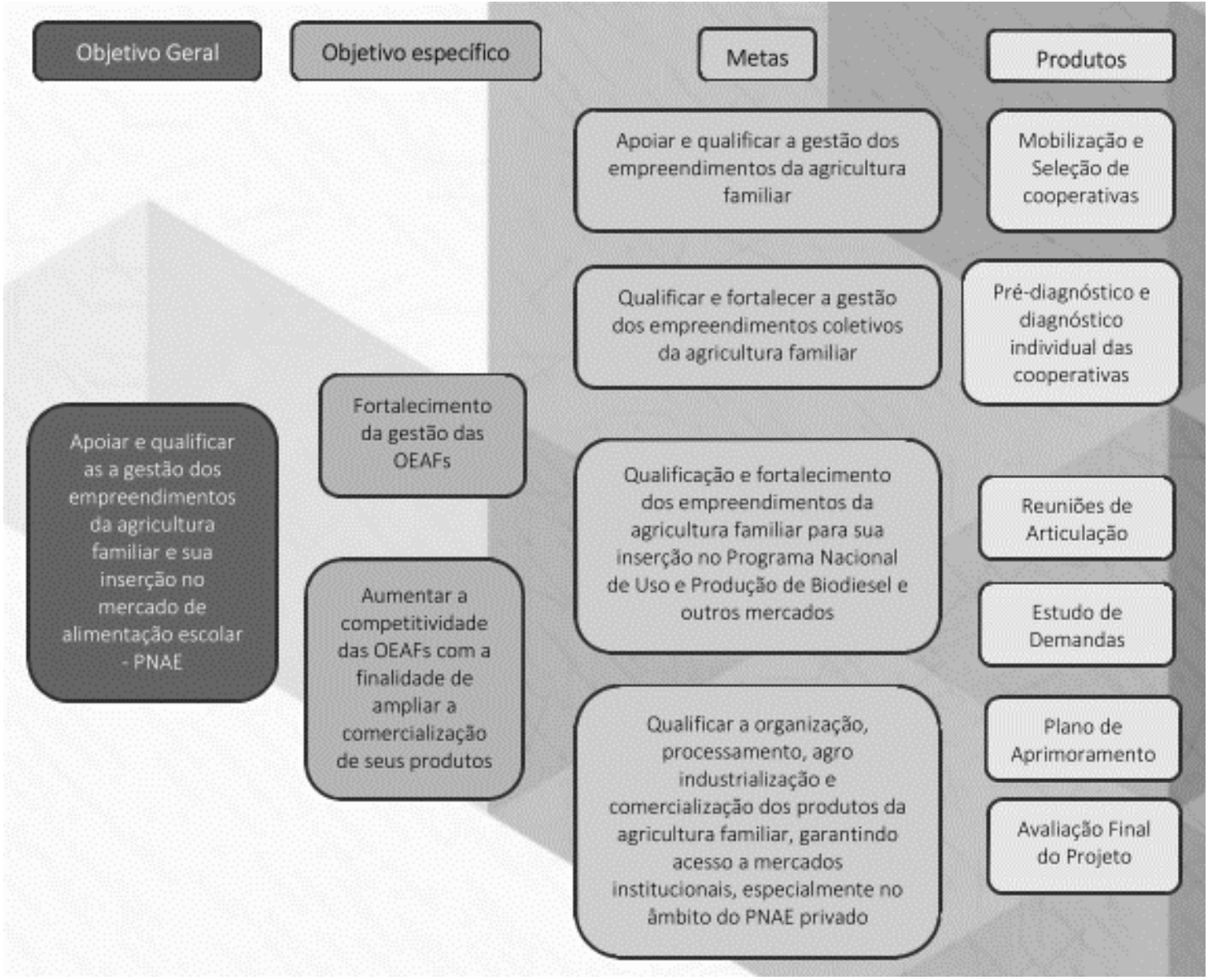

Fonte: Rede de Universidades na Avaliação do Programa Mais Gestão (BRASIL, 2016b).

A entidade contratada para desenvolver a metodologia deveria apresentar uma equipe técnica multidisciplinar, composta por técnicos de nível superior, a fim de atender a Lei $\mathrm{n}^{\circ} 12.188 / 10$ e o contido no art. $6^{\circ}$ do Decreto $\mathrm{n}^{\circ} 7.215 / 10$. Com relação ao número de técnicos, esse era definido pelo lote e qualquer substituição dos membros da equipe deveria ser autorizada pelo contratante (BRASIL, 2016b).

Após a adaptação da metodologia, as primeiras chamadas públicas do Programa Mais Gestão foram lançadas com base na Nova Lei de Ater. Foram, ao todo, quatro chamadas públicas, todas distintas, porém, como o objetivo principal de melhorar a gestão e promover o acesso aos mercados, conforme evidenciado no Quadro 1 (AVILA et al., 2015). 
Quadro 1 - Chamadas públicas lançadas pelo MDA para contratação de entidades executoras de ATER, com vistas a executar o Programa Mais Gestão e valores envolvidos.

\begin{tabular}{|c|c|c|}
\hline Chamada pública & $\underline{\text { Objetivo }}$ & $\underline{\text { Valor envolvido }}$ \\
\hline $\begin{array}{l}\text { Chamada } \\
\text { Pública } \\
\text { SAF/ATER } n^{\circ} \\
04 / 2012\end{array}$ & $\begin{array}{c}\text { Seleção de entidades executoras de serviços de ATER para } \\
\text { qualificação da gestão, apoio ao fortalecimento e à inserção } \\
\text { de cooperativas da agricultura familiar no Programa Nacional } \\
\text { de Alimentação Escolar e outros mercados. }\end{array}$ & $\mathrm{R} \$ 25.026 .700,82$ \\
\hline $\begin{array}{l}\text { Chamada } \\
\text { Pública } \\
\text { SAF/ATER } n^{\circ} \\
06 / 2012\end{array}$ & $\begin{array}{l}\text { Seleção de entidades executoras de serviços de ATER para } \\
\text { qualificação da gestão de empreendimentos coletivos da } \\
\text { agricultura familiar visando seu fortalecimento e inserção nos } \\
\text { mercados institucionais e privados. }\end{array}$ & $\mathrm{R} \$ 37.607 .053,88$ \\
\hline $\begin{array}{l}\text { Chamada } \\
\text { Pública } \\
\text { SAF/ATER n } \\
07 / 2012\end{array}$ & $\begin{array}{l}\text { Seleção de entidades executoras de serviços de ATER para } \\
\text { qualificação da gestão, fortalecimento e inserção de } \\
\text { empreendimentos coletivos da agricultura familiar no } \\
\text { Programa Nacional de Uso e Produção do Biodiesel e outros } \\
\text { mercados. }\end{array}$ & $\mathrm{R} \$ 4.154 .112,94$ \\
\hline $\begin{array}{l}\text { Chamada } \\
\text { Pública } \\
\text { SAF/ATER } n^{\circ} \\
17 / 2013\end{array}$ & $\begin{array}{c}\text { Seleção de entidades executoras de serviços de ATER para } \\
\text { qualificação da gestão, fortalecimento e inserção de } \\
\text { cooperativas da agricultura familiar nos mercados } \\
\text { institucionais, públicos e privados. }\end{array}$ & $\mathrm{R} \$ 4.904 .570,53$ \\
\hline \multicolumn{2}{|r|}{ TOTAL } & $\mathrm{R} \$ 71.692 .438,17$ \\
\hline
\end{tabular}

Fonte: dados da pesquisa.

As chamadas públicas supracitadas possibilitaram a contratação de 13 equipes de ATER multidisciplinares, que atenderam 448 cooperativas em 18 estados brasileiros, conforme Quadro 2.

Quadro 2 - Quantidade de cooperativas e estados beneficiados, por edital.

\begin{tabular}{|c|c|c|}
\hline Chamada Pública & Total de cooperativas & Estados abrangidos \\
\hline $\begin{array}{c}\text { Chamada Pública SAF/ATER n } \\
04 / 2012\end{array}$ & 201 & $\begin{array}{c}\text { MA, PI, CE, RN, PB, PE, AL, } \\
\text { SE, MG, SP, PR, SC e RS }\end{array}$ \\
\hline $\begin{array}{c}\text { Chamada Pública SAF/ATER n } \\
\text { 06/2012 }\end{array}$ & 168 & $\begin{array}{c}\text { RS, RN, PI, PB, GO, MG, SP, } \\
\text { PR e SC }\end{array}$ \\
\hline $\begin{array}{c}\text { Chamada Pública SAF/ATER n } \\
\text { 07/2012 }\end{array}$ & 24 & $\begin{array}{c}\text { CE, PE, SE, BA, MG, GO, MT e } \\
\text { MS }\end{array}$ \\
\hline $\begin{array}{c}\text { Chamada Pública SAF/ATER n } \\
\text { 17/2013 }\end{array}$ & 55 & BA e ES \\
\hline
\end{tabular}

Fonte: Rede de Universidades na Avaliação do Programa Mais Gestão (BRASIL, 2016a).

As ações descritas nas Chamadas Públicas são focadas na criação de soluções para melhoria da gestão das cooperativas, por meio da ATER coletiva. O objetivo dos serviços prestados é a efetiva realização, ampliação e qualificação da atuação das cooperativas de agricultura familiar na cadeia produtiva, e também da comercialização para os mercados institucionais, por meio da elaboração de planos de aprimoramento. 
O serviço ofertado pelas equipes de ATER deveria ser realizado em sinergia com os cooperados. Nesse aspecto, a cooperativa participante do PMG se comprometeu a realizar um trabalho articulado e contínuo junto às equipes. Isso porque a metodologia da ATER deve ter um caráter educativo, com ênfase na pedagogia da prática, promovendo a geração e apropriação coletiva de conhecimentos, conforme indica a Política Nacional de ATER. A metodologia do Programa é dividida nas seguintes etapas:

(1) Sensibilização e adesão informada:

Nesta etapa a metodologia é apresentada aos empreendimentos e em seguida os interessados são convidados a assinar o Termo de Adesão ao projeto. Em seguida faz-se o "Levantamento prévio de informações" sobre os empreendimentos cooperados através de um questionário e o agendamento das visitas técnicas para a fase do diagnóstico.

(2) Diagnóstico dos empreendimentos:

O diagnóstico das cooperativas é feito por meio de visita dos técnicos extensionistas que fazem entrevistas (orientadas por um Formulário de Diagnóstico) e observações diretas. O Formulário de Diagnóstico abrange diversas áreas funcionais do empreendimento como: Gestão Organizacional, Finanças e Custos, Gestão de Pessoas, Comercialização e Marketing, Gestão Industrial e Gestão Ambiental. Com as informações obtidas pelo Formulário de Diagnóstico, forma-se a Matriz de Identificação Estratégica (MIE), demonstrando a situação das áreas funcionais de cada empreendimento;

(3) Elaboração dos Planos de Aprimoramento:

O Plano de Aprimoramento é elaborado com base no diagnóstico e pactuado com os empreendimentos. $\mathrm{O}$ documento analisa o desempenho dos empreendimentos por área funcional e indica ações a serem implantadas.

(4) Implantação de soluções:

A fase de implantação de soluções nos empreendimentos integra as seguintes estratégias: Assistência técnica orientada pelos Planos de Aprimoramentos; Matriz de Atendimento de Demanda e soluções que devem ser implantadas pelos próprios gestores dos empreendimentos. As soluções poderão ser individuais e/ou de conjuntos. As individuais atendem às necessidades de assistência técnica e extensão industrial de um empreendimento e as de conjunto baseiam-se na identificação de desafios comuns e 
implicam, portanto, em ações que podem beneficiar, num só tempo, vários empreendimentos. A sistemática de funcionamento do PMG pode ser melhor compreendida a partir de Figura 11:

Figura 11 - Sistemática de funcionamento do Programa Mais Gestão.

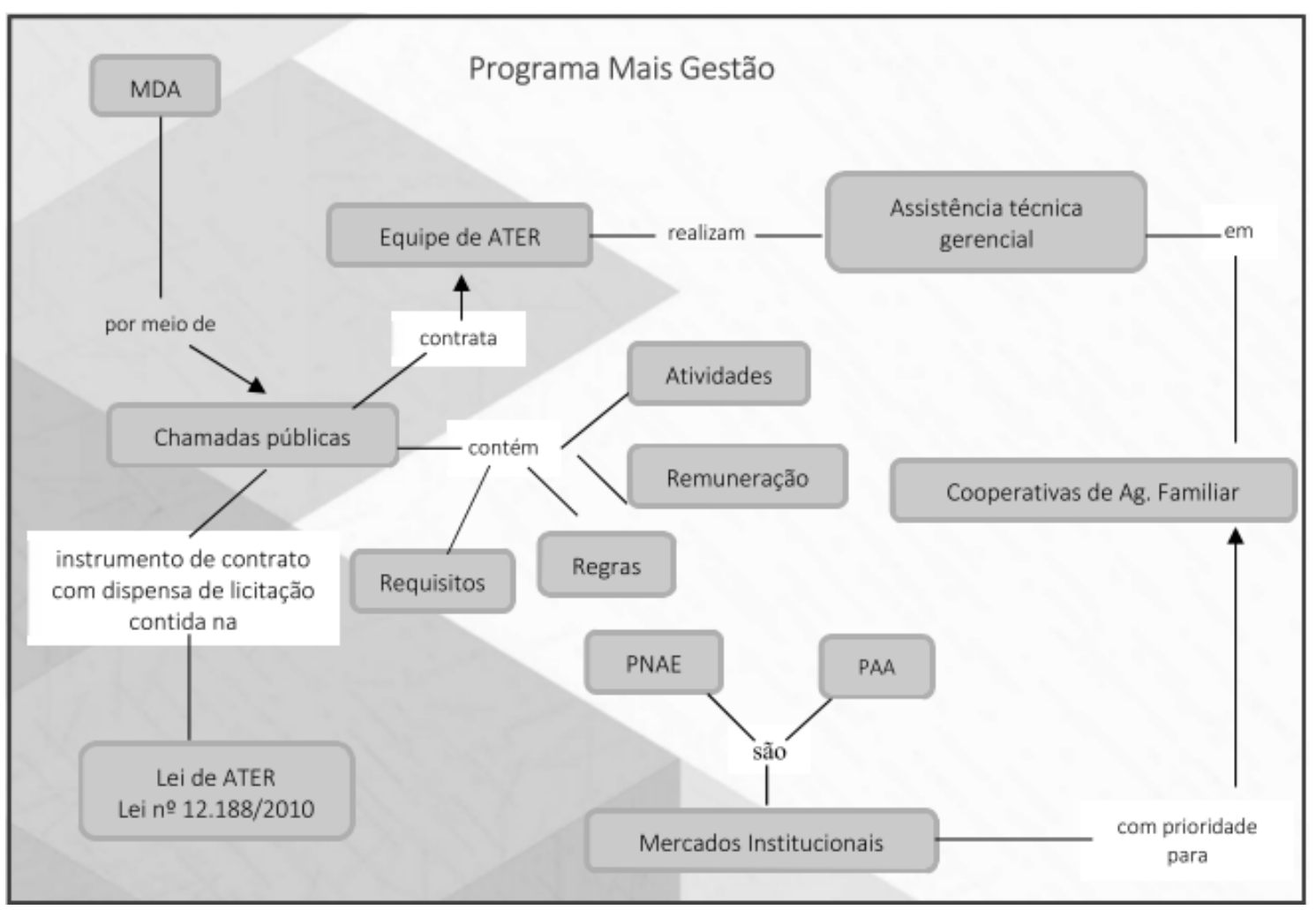

Fonte: Rede de Universidades na Avaliação do Programa Mais Gestão (BRASIL, 2016b)

Os principais resultados obtidos após o emprego da metodologia relacionam-se a:

- Fortalecimento do associativismo e o desenvolvimento institucional de empreendimentos da Agricultura Familiar;

- Ampliação do acesso a produtos e serviços de apoio disponíveis nas instituições de governo e setor privado;

- Implantação de melhorias técnico-gerenciais e tecnológicas nos empreendimentos;

- Aumento expressivo no desempenho dos empreendimentos; contribuindo para a elevação dos níveis de emprego e renda;

- Desenvolvimento da capacitação para a inovação

- Promoção do protagonismo dos empreendedores familiares na interação entre as cooperativas e instituição de apoio e cooperação.

A necessidade de solucionar os diversos problemas e atender a objetivos tão destoantes um do outro, mesmo que voltados para um único público, foi o que justificou 
a necessidade de o PMG contar com profissionais ecléticos nas equipes de ATER. Esse diferencial, inclusive, foi uma das inovações do programa, que permitiu maior abrangência e resolução dos problemas.

Embora apresente a necessidade de integração e sinergia de equipe de ATER e cooperado, o PMG é caracterizado como uma política pública top-down, em que as decisões e propostas são oriundas dos formuladores da política. No entanto, mesmo sendo uma política top-down, o instrumento jurídico responsável por contratar as entidades de ATER, permitiu que as equipes tivessem maior influência sobre a oferta de assistência técnica durante a execução da metodologia às cooperativas, mesmo com as etapas prédefinidas.

Essa influência que os técnicos assumem se deve ao fato de que as cooperativas atendidas têm características e problemas diferentes, embora o objetivo do governo seja único, garantir oferta para a demanda dos mercados institucionais. Essa liberdade que as equipes de ATER necessitam para solucionar os problemas que envolvem questões administrativas, produtivas, econômicas, sanitárias, ambientais e legais era constantemente vigiada pelo Ministério, pois, para garantir o pagamento estabelecido, deve-se atender aos requisitos da chamada.

As atividades desenvolvidas pelas equipes de ATER foram realizadas de forma segmentada. Primeiro a coleta de dados, análise de informações, elaboração de plano de aprimoramento e assim por diante. À medida em que iam sendo desenvolvidas as atividades, os agentes enviavam para o MDA para que fosse analisado o produto e posterior pagamento. Essa questão de se ter a contratação via chamadas públicas engessa e limita as ações dos agentes, dificultando assim a metodologia participativa, visto que conforme exposto, os produtos devem atender ao que está pré-estabelecido.

Convém ressaltar que o Programa Mais Gestão não dispunha de um Decreto ou Lei de institucionalização. O Programa contava com o suporte legal e estruturava-se como ação dentro do Programa Nacional de Assistência Técnica e Extensão Rural (Pronater) e da Política Nacional de Assistência Técnica e Extensão Rural (PNATER) (BRASIL, 2016b). A falta de um marco-jurídico específico tornou vulnerável o Programa ameaçando sua continuidade diante de mudanças políticas. 


\section{As cooperativas do Programa Mais Gestão}

Embora uma caracterização das cooperativas atendidas pelo Programa não seja uma das fases do ciclo, é importante evidenciar as características das mesmas. Como o Programa foi gerado sem um diagnóstico que evidenciasse qual era a realidade das organizações e o que elas necessitavam, nem ao menos o MDA tentou dividir os beneficiários conforme sugeriu a Casa Verde. Essa caracterização é compreendida como fundamental, pois é capaz de subsidiar a melhoria dos programas ou até mesmo a criação de novas políticas com ênfase a esse setor.

As informações a seguir apresentadas são resultado da análise dos dados coletados durante a etapa inicial executada pelas entidades de ATER contratadas, mediante a aplicação de dois formulários: um de caracterização e outro de práticas gerenciais (BRASIL, 2016a).

É significativo observar o número de associados atendidos pelo Programa, conforme mostrado na Tabela 6. Cabe atenção também destacar o elevado número de associados que não possuem DAP, o que reflete a incipiente formalização dos cooperados.

Tabela 6 - Síntese dos dados das cooperativas atendidas pelo Programa Mais Gestão.

\begin{tabular}{lc}
\multicolumn{1}{c}{ Variável } & Total \\
\hline Associados & 99.123 \\
\hline Associados com DAP & 82.353 \\
\hline Faturamento Total & $\mathrm{R} \$ 922.191 .950,54$ \\
\hline Faturamento Institucional & $\mathrm{R} \$ 313.758 .954,48$ \\
\hline Patrimônio & $\mathrm{R} \$ 331.294 .865,59$ \\
\hline
\end{tabular}

Fonte: dados da pesquisa.

Não divergindo de outros dados, como apresentado na Figura 12, a região Sul é a que se destaca no que se refere à quantidade de sócios, seguido do Sudeste, Nordeste e por último o Centro-Oeste. O que gera reflexões é a diferença entre o número de sócios; sócios ativos; associados com DAP e sócios ativos com DAP. 
Figura 12 - Quantitativo de sócios, sócios ativos, associados com DAP e sócios ativos com DAP, por região.

\section{Associados Totais e com DAP por Região}

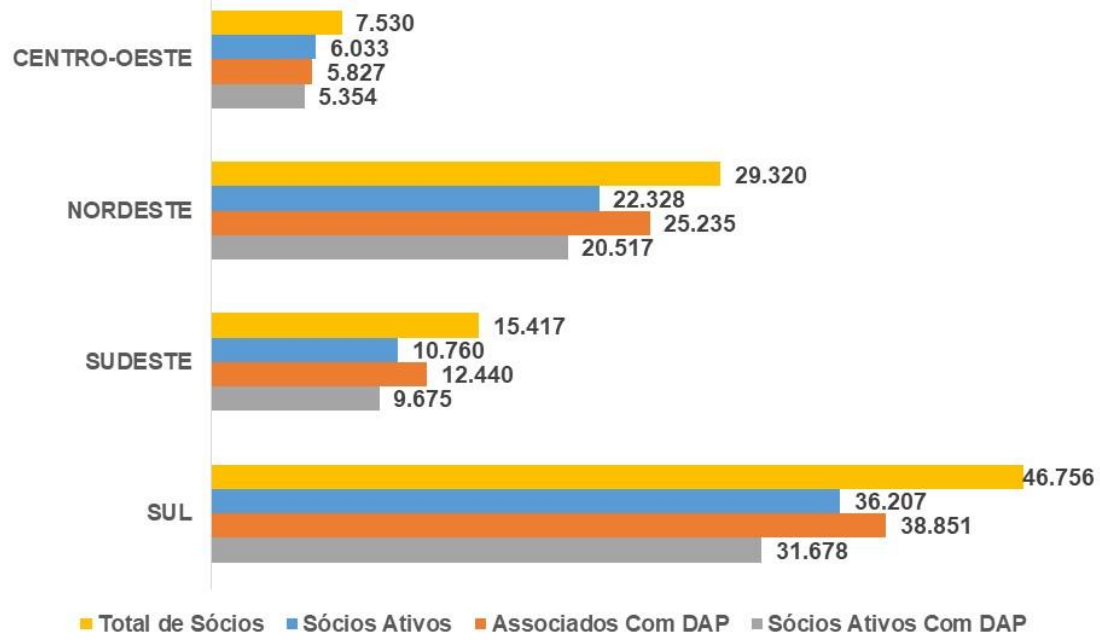

Fonte: dados da pesquisa.

Diferentemente de alguns outros dados, a região Nordeste é apontada como a que mais possui mulheres associadas com DAP. A Figura 13 revela a ainda pequena expressividade com relação à representatividade das mulheres, nas demais regiões brasileiras.

Figura 13 - Quantitativo de associados com DAP por região, total $x$ mulheres.

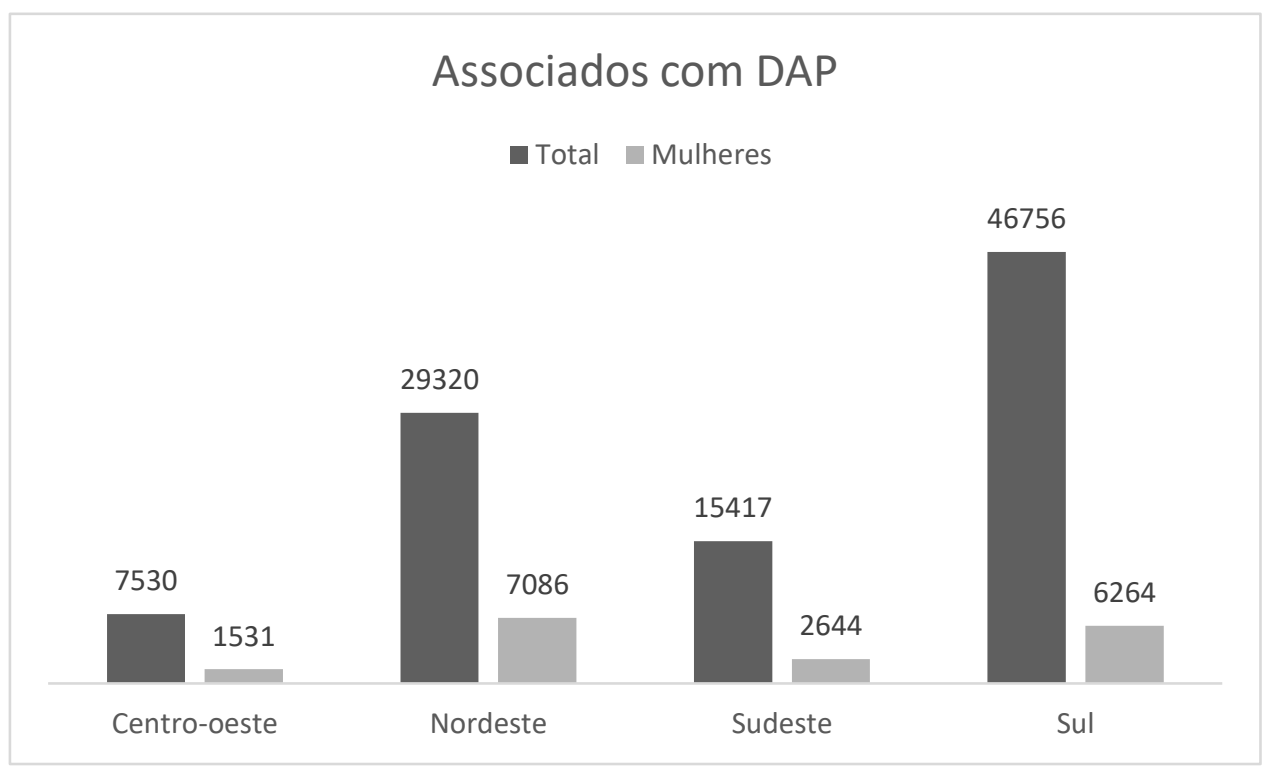

Fonte: dados da pesquisa. 
Durante as entrevistas, uma pergunta girava em torno da questão de acesso a ATER. Nesse aspecto, é possivel perceber, conforme Figura 14 a necessidade de ampliar a oferta de ATER via entidades públicas, visto que com exceção da região Sul e com uma pequena diferença para a região Centro-Oeste, a realidade é que o número de organizacões que não acessam a ATER pública, supera as que acessam.

Figura 14 - Porcentagem das cooperativas atendidas pelo Programa Mais Gestão que acessaram a ATER via entidades públicas. $(\mathrm{N}=443)$.

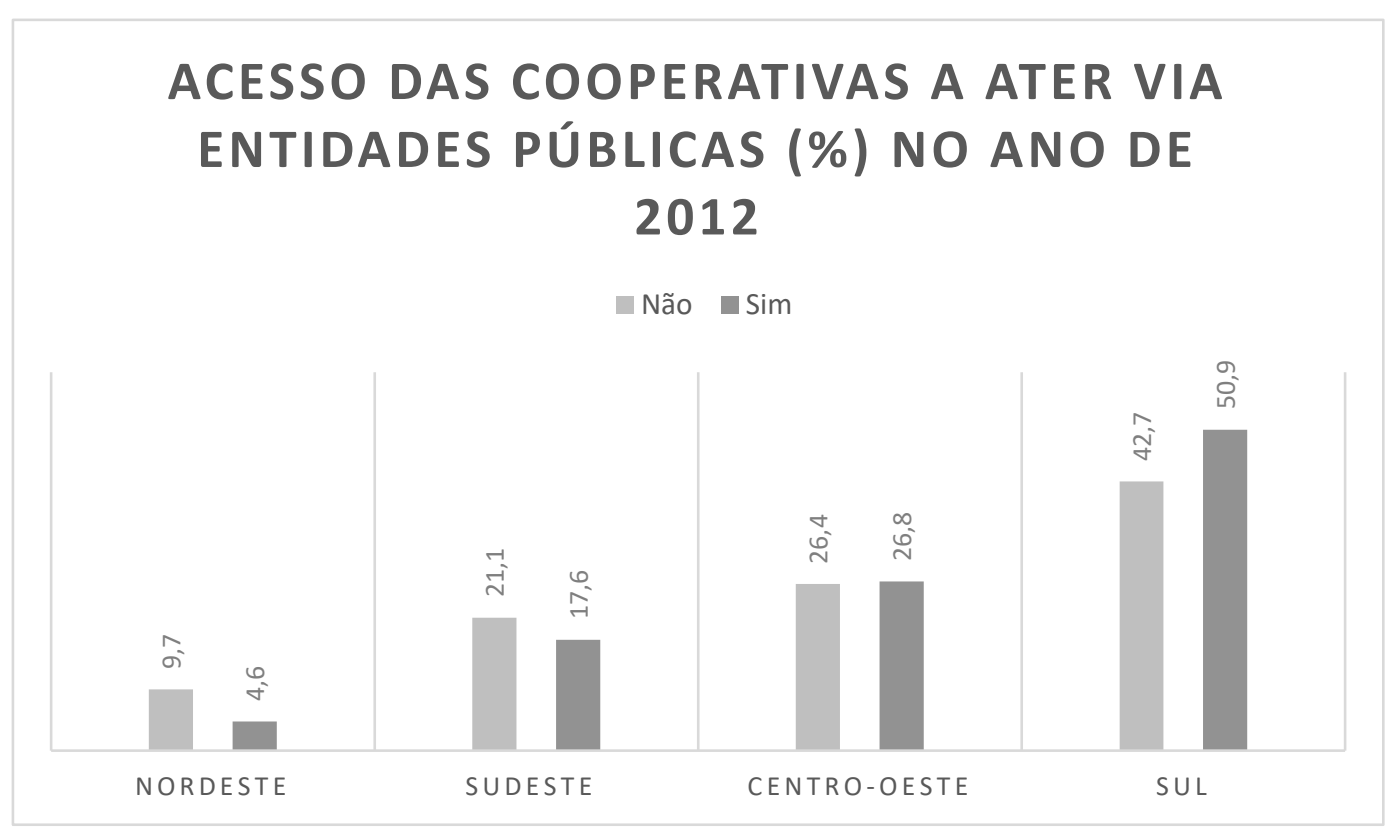

Fonte: Secretaria Especial de Agricultura Familiar e do Desenvolvimento Agrário (BRASIL, 2016a)

Os dados da Tabela 7 revelam a representatividade do PAA, PNAE e PNPB para as cooperativas. Além de revelar o aumento do faturamento, ano após ano, com exceção do PNPB, os dados indicam que foi crescente o número de cooperativas que vendiam por via desses programas.

Tabela 7 - Valor de faturamento das cooperativas atendidas pelo Programa Mais Gestão ao PAA, PNAE e PNPB e respectivo número de cooperativas que acessam aos mercados.

Faturamento PAA, PNAE e PNPB nos anos 2010, 2011 e 2012

\begin{tabular}{|c|c|c|c|c|c|c|c|c|}
\hline \multirow{2}{*}{$\begin{array}{l}\text { Ano } \\
2010\end{array}$} & \multirow{2}{*}{$\begin{array}{l}\mathrm{N} \\
92\end{array}$} & \multicolumn{2}{|c|}{ Faturamento PAA } & \multirow{2}{*}{$\begin{array}{l}\mathrm{N} \\
87\end{array}$} & \multicolumn{2}{|c|}{ Faturamento PNAE } & \multirow{2}{*}{$\begin{array}{l}\mathrm{N} \\
11\end{array}$} & \multirow{2}{*}{$\begin{array}{l}\text { Faturamento PNPB } \\
\text { R\$ } 194.115 .254,00\end{array}$} \\
\hline & & $\mathrm{R} \$$ & $35.704 .856,00$ & & $\mathrm{R} \$$ & $13.295 .814,00$ & & \\
\hline & 120 & $\mathrm{R} \$$ & & & & & & $76.108 .491,00$ \\
\hline 2012 & 171 & $\mathrm{R} \$$ & $74.420 .374,00$ & 235 & $\mathrm{R} \$$ & $80.443 .165,00$ & 21 & $\mathrm{R} \$ 104.741 .896,00$ \\
\hline
\end{tabular}

Fonte: Secretaria Especial de Agricultura Familiar e do Desenvolvimento Agrário (BRASIL, 2016a).

O crescimento no número de respondentes para faturamento de mercados institucionais indica que entre 2010 a 2012 um maior número de cooperativas conseguiu 
acessar os programas PAA, PNAE e PNPB. Esse crescimento está em acordo com as informações anteriormente detalhadas, no capítulo 2 , no que se refere às aquisições da agricultura familiar e também dos recursos investidos pelos três programas.

A Figura 15 permite uma observação clara da comercialização diversificada das organizações atendidas. As cooperativas atendidas pelo Programa produzem desde frutas e derivados, perpassando por carnes ou até mesmo artesanato. Esse ponto revela também a necessidade de se classificar as organizações por características, conforme orientado inicialmente pela Casa Verde.

Figura 15 - Quantidade de cooperativas atendidas pelo Programa Mais Gestão segundo os principais produtos comercializados em 2012.

\section{Quantidade de cooperativas segundo os principais produtos comercializados}

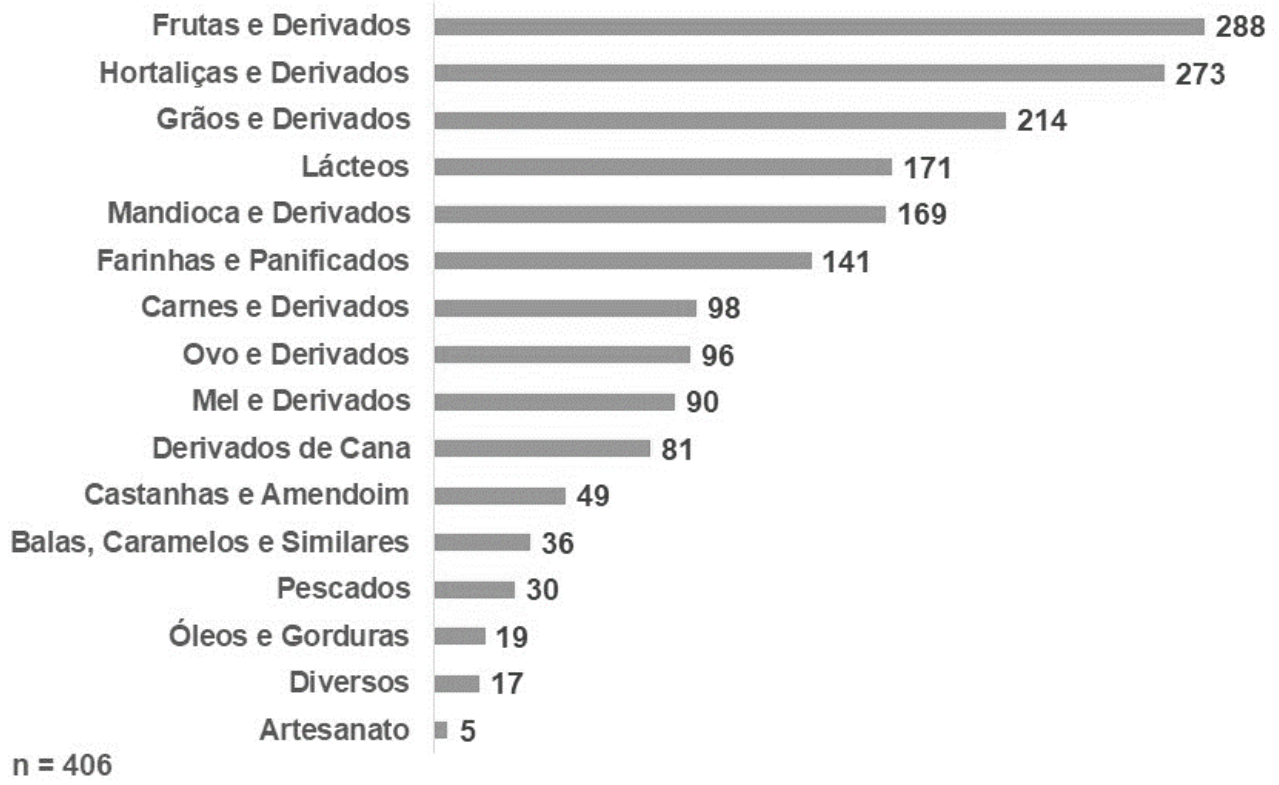

Fonte: dados da pesquisa.

Diante dessa sucinta caracterização é importante ressaltar o elevado número de beneficiados com o Programa e também suas distinções. O PMG não atendeu apenas cooperativas estruturadas que careciam de assistência durante a produção e venda de verduras. Os técnicos de ATER encontraram realidades extremamente distintas, com variadas carências, inclusive, carências mínimas de gestão, revelando que algumas 
cooperativas necessitavam de uma maior assistência técnica, fato que pode estar atrelado principalmente à idade de tais organizações (BRASIL, 2016a).

\section{Monitoramento e avaliação}

A metodologia utilizada pelo Mais Gestão remete a organizações e produtos já estabelecidos, no entanto, da teoria à prática há uma distância considerável e para que os objetivos sejam cumpridos, as equipes adequam-se internamente para melhor atender ao Programa. O Ministério estruturou o PMG por meio de uma relação de fiscalização por contratos, assim, foi atribuído a um funcionário a responsabilidade de conferir e fiscalizar um dado contrato, sendo autorizado o pagamento apenas quando o funcionário entende que os produtos estavam a contento (AVILA et al., 2015).

Outra questão que revela inovação do programa é a questão de monitoramento e avaliação. Além da fiscalização por parte dos fiscais de contratos, o Ministério compôs o Projeto Rede de Universidades na Avaliação do Programa Mais Gestão, por meio do Termo de Execução Descentralizada (TED) Nº46/2014, de 10 de novembro de 2014. A despesa do referido TED tinha como objeto:

\footnotetext{
Instituir e articular a Rede Mais Gestão de Universidades, para desenvolver estudos, pesquisa e inovação na área de gestão das cooperativas e demais organizações econômicas da agricultura familiar estimulando o desenvolvimento de processos de monitoramento, avaliação, geração de informação e conhecimento, assim como a execução de atividades de interesse dos pactuantes que convirjam para o esforço comum no desenvolvimento de capacidades e o aperfeiçoamento das políticas públicas (BRASIL, 2014a).
}

Desse modo, a Rede foi composta com o intuito de gerar produção de informações e conhecimento, subsidiar o monitoramento e a avaliação do PMG e fomentar ainda a produção acadêmica sobre o desenvolvimento econômico das cooperativas de agricultura familiar (BRASIL, 2014a). Foram definidas como atividades da Rede:

(1) Uma oficina para formação dos núcleos de pesquisa e definição dos parâmetros a serem trabalhados no projeto.

(2) Seis reuniões de articulação da Rede de Universidades.

(3) Elaborar e publicar três livros com os dados e análises produzidas pelos pesquisadores no âmbito do Projeto.

(4) Diagnosticar da realidade organizacional das 450 cooperativas atendidas no âmbito do Mais Gestão, resultando em um banco de dados. 
(5) Realizar análise da base de dados disponíveis no âmbito do PMG e outras bases secundárias.

(6) Elaborar documento contendo análise da realidade organizacional das 450 cooperativas, com a análise dos dados primários e secundários sobre este universo.

(7) Elaborar oito estudos acerca dos principais gargalos enfrentados pelos empreendimentos da agricultura familiar brasileiros com DAP Jurídica, tendo como objetivo, estabelecer uma tipologia única, mas que comporte recorte regional, sobre os níveis de desenvolvimento e complexidade organizacional das cooperativas, para possibilitar o desenvolvimento de políticas públicas de apoio específicas para cada estrato.

(8) Realizar um seminário para apresentação da tipologia das organizações econômicas da agricultura familiar construída pelo Projeto.

(9) Apresentar a avaliação do Programa Mais Gestão, por meio de 6 documentos, considerando os tipos e encadeamento das atividades contratadas; perfil e quantidade dos técnicos de cada equipe; quantidades de cooperativas, abrangência dos lotes; valores destinados; caráter consultivo, técnico-participativo, multidisciplinar.

(10) Realizar dois seminários de avaliação dos dados, com participação de representantes das cooperativas, da sociedade civil, governos ou outros atores relacionados à temática.

(11) Desenvolver o programa de inicial profissional no cooperativismo “Jovem Cooperativista” (BRASIL, 2014a, p. 2-3).

A Rede Mais Gestão de Universidades foi coordenada pela Universidade Federal de Viçosa (UFV) com recursos do MDA. Foram instituídos cinco núcleos regionais (Norte, Nordeste, Centro-Oeste, Sudeste e Sul), envolvendo 11 instituições federais de ensino superior.

O Projeto inicialmente possuía a pretensão de durar dois anos, com o objetivo de aperfeiçoar as políticas públicas para as cooperativas da agricultura familiar, incluindo também o Programa Mais Gestão. Conforme apontou o coordenador da rede, senhor Marcelo Braga, professor do Departamento de Economia Rural da UFV: "Vamos 
fornecer elementos para que o Ministério do Desenvolvimento Agrário possa avaliar e lançar um programa mais aprimorado, identificando os problemas de implementação, os gargalos das cooperativas e os problemas que elas enfrentam" (UFV, 2015). Além disso, o Projeto Mais Gestão potencializa a tríade ensino, pesquisa e extensão, conforme exaltou a professora Eliene Anjos, docente da Universidade Federal do Recôncavo Baiano:

\begin{abstract}
Primeiro porque impulsionou as instituições de ensino a criar uma Rede de Universidades voltada para a gestão das cooperativas, feito inovador no campo acadêmico. Segundo porque fortalece as OEAF com a avaliação da política pública que está sendo desenvolvida pelo MDA com 448 cooperativas atendidas no Brasil. Terceiro porque está propiciando um processo de ensino integrador com o Programa Jovem Cooperativista (UFRB, 2015).
\end{abstract}

A criação da Rede de Universidades permitiu diversos encontros entre os integrantes, como o I Seminário da Rede de Universidades na Avaliação do Programa Mais Gestão que ocorreu entre os dias 24 a 27 de fevereiro de 2015, na UFV e também a Oficina da Rede de Universidades que ocorreu entre os dias 19 a 23 de outubro do mesmo ano, na UFRB. Tais encontros proporcionaram o delineamento metodológico do programa, além de estimular os processos de monitoramento, avaliação e promoção de conhecimento.

Dentre as diversas entrevistas realizadas pela Rede, uma em especial com um técnico do MDA, apontou que entre uma chamada e outra, da Chamada 04 lançada no ano de 2012 e a Chamada 17, lançada em 2013, foi observada a necessidade de melhorias. Segundo o técnico seria necessário realizar um estudo da realidade em que a cooperativa atua, porém, como a chamada é feita por contrato "isso dificultou a operacionalização das mudanças desejadas. No contrato, os valores e atividades são bem amarrados" (E14, 2015).

Além dos encontros entre os pesquisadores, a equipe da Rede realizou diversas visitas em cooperativas e também conversas com algumas equipes de ATER. Os estudos de Nascimento et al. (2016) apontaram a heterogeneidade presente nas cooperativas brasileiras, fato que deve ser levado em conta durante a formulação de políticas, e também a existência de diversos gargalos no que condiz a gestão das organizações.

Os objetivos específicos do PMG eram fortalecer a gestão das cooperativas e ampliar a comercialização de seus produtos. Para realizar tais objetivos, o Ministério contava que as cooperativas detentoras de DAP Jurídica possuíssem uma mínima organização administrativa, necessitanto apenas de melhorias. No entanto, conforme 
apontaram Nascimento et al. (2016), foram diversos os problemas encontrados pelas equipes de ATER, concernentes, até mesmo, a problemas básicos, tais como a falta de recursos, estrrutura e capacitação para atender as cooperativas em diversas regiões.

A partir de diálogos com as equipes de ATER, foram apontadas dificuldades com relação à logística e rotatividade dos técnicos, além da carência de estrutura e recursos. Tais apontamentos, como as dificuldades com logística, já estavam sendo considerados para a criação de novas chamadas públicas para contratação de equipes de ATER (NASCIMENTO et al., 2016).

O PMG trouxe, desse modo, inúmeros benefícios para os agricultores familiares, conforme apontaram São José, Pereira e Oliveira (2017). A partir do momento em que as cooperativas aderiram ao Mais Gestão, foi nítido o aumento de participação das mesmas na comercialização para mercados institucionais. $\mathrm{O}$ fato reforça ainda mais a necessidade de interação entre os envolvidos. Reforçando essa questão, o senhor Demétrio D’Ega, presidente da Cooperativa dos Pequenos Produtores Rurais e Trabalhadores Autônomos na Agropecuária (Coomtrata), do município de Nazaré, interior da Bahia, atendida pelo Programa Mais Gestão, ressaltou potencialidades do Programa, como:

Para nós, o Ater Mais Gestão foi extremamente importante em função da
carência de assistência que nós temos aqui na região. O programa também
conscientizou os cooperados do porquê de eles estarem associados, do valor
do cooperativismo. Nós também conseguimos vender nossos produtos para o
PNAE, ganhamos o acompanhamento para os produtores, e com isso teve
agricultor que até conseguiu montar seu próprio comércio dentro da
propriedade. Agora estamos focados na comercialização e em fechar contratos
com empresas para vender o dendê para a produção de biodiesel com uma
usina que estamos implantando (BRASIL, 2017b).

De acordo com dados da Secretaria Especial de Agricultura Familiar e do Desenvolvimento Agrário (SEAD), em maio do ano de 2017, foram encerradas as atividades do Programa Mais Gestão em oito estados brasileiros, com um balanço positivo. A analista técnica de Políticas Sociais da Coordenação Geral de Biocombustíveis da Sead, Mariana Carrara, apontou o diferencial do PMG em auxiliar os agricultores a solucionarem questões voltadas para a inserção dos produtos nos mercados e acesso às políticas públicas (BRASIL, 2017b).

Conforme indica a Rede de Universidades, um quarto das cooperativas atendidas podia ser considerado grande, $50 \%$ delas eram consideradas micro e $25 \%$ pequenas. Uma reflexão levantada pelos participantes aponta para a assertividade de um programa único atendendo a todos os portes de cooperativas. Uma hipótese é que "o programa possa ser 
insuficiente para auxiliar as grandes e demasiado na demanda de estrutura mínima para aquelas categorizadas como micro" (BRASIL, 2016a, p. 14).

No que condiz ao apresentado pelo diagnóstico elaborado pela Rede de Universidades na Avaliação do Programa Mais Gestão, foi observado que menos da metade das cooperativas atendidas acessavam ao PRONAF e as linhas de crédito do Banco Nacional do Desenvolvimento (BNDES). Esse fator aponta para a necessidade de mais estudos sobre o público atendido e que talvez seja necessário desenhar uma nova política de incentivo via crédito (BRASIL, 2016a).

Além dessa questão de acesso a crédito, foi possível observar que grande parte das cooperativas desenhavam sua missão e visão de futuro, no entanto, menos de $10 \%$ delas realizavam planejamento estratégico. Complementando, a maior parte delas não tinham estabelecidas as funções, responsabilidades e atividades a serem desenvolvidas (BRASIL, 2016a). 


\section{Breves considerações}

A análise do Programa Mais Gestão, ancorada no ciclo de política públicas, permitiu a compreensao de cada uma de suas fases, desde a origem do problema que o concebeu. O PMG foi criado com vistas a promover o acesso de cooperativas da agricultura familiar aos mercados institucionais, em particular o PAA, PNAE e PNPB.

Além de atender a um público específico, o Programa inovou ao ofertar assistência técnica coletiva, que não estava atenta somente a questões produtivas, como a ATER tradicional. O PMG buscou aprimorar as questões técnicas e gerenciais.

Com o intuito de monitorar a execução do Programa Mais Gestão, o extinto MDA, responsável pela concepção do $\mathrm{PMG}$, idealizou um projeto que reunisse diversas instituições federais para que elas pudessem monitorar e avaliar o programa, dando suporte ainda para futuras inovações e também para a geração de conhecimento. Esse projeto, denominado Rede de Universidades na Avaliação do Programa Mais Gestão foi responsável por identificar as características das cooperativas atendidas, além de ter realizado análises condizentes com a formulação e implementação do Programa. 


\section{A DESCONTINUIDADE DO PROGRAMA MAIS GESTÃO E SEUS CONDICIONANTES}

\section{Introdução}

Após a compreensão do ciclo de vida do Programa Mais Gestão, é possível analisar a fundo como o mesmo foi descontinuado e quais as origens para tal fato. A explicação dessa fase do ciclo está ancorada na teoria dos fluxos múltiplos (SOUZA; SECCHI, 2015), conforme explicitado no capítulo 2. A justificativa para a escolha dessa teoria está baseada no fato de que os fluxos múltiplos são capazes também de explicar a gênese do PMG.

Nesse capítulo serão desenrolados os condicionantes da descontinuidade do Programa Mais Gestão. Pressupõe-se que a avaliação não foi o fator determinante para que o programa fosse descontinuado. Diante disso, os fluxos múltiplos associados às fases do ciclo de vida do Programa exploicam a descontinuidade do mesmo. 


\section{A descontinuidade do Programa Mais Gestão}

Embora o Programa Mais Gestão não tenha sido avaliado por um período considerável para compreensão e análise de seus resultados, os resultados primários indicam que o PMG teve um alcance relevante, por atuar em mais de 400 cooperativas em quase todas as regiões brasileiras. Tais dados indicavam a continuação do mesmo, o que foi iniciado com a publicação de uma nova chamada pública para contratação de equipes de ATER (Chamada Pública SAF/ATER n 02/2016).

A Chamada Pública SAF/ATER de maio de 2016 tinha por objeto a seleção de entidades de ATER para qualificação de gestão, apoio ao fortalecimento e à inserção de organizações econômicas da agricultura familiar nos mercados institucionais, públicos e privados. O valor total estimado para a chamada era de $\mathrm{R} \$ 208.499 .816,25$, beneficiando 930 organizações de agricultores familiares detentoras de DAP Jurídica (BRASIL, 2016f).

Conforme observado, as políticas públicas para agricultura familiar obtiveram maior atenção governamental durante o governo do ex-presidente Lula. A ex-presidente Dilma Rousseff deu continuidade às ações já iniciadas nos governos anteriores, ressaltando a agricultura familiar. Durante a atuação dos governos Lula e Dilma, o MDA foi protagonista de ações que visavam a melhoria da distribuição de renda, enfrentamento da fome e da pobreza e a redução das desigualdades sociais e regionais (MATTEI, 2016).

A situação crítica para o governo da ex-presidente Dilma Rousseff teve início em junho de 2013, durante seu primeiro mandato, com o surgimento de protestos que apontavam para o descontentamento de parte da população para com os políticos. No ano de 2014, com a operação Lava-Jato ${ }^{7}$, os escândalos políticos agravaram ainda mais a situação política do país.

Em dezembro de 2015, o pedido de impeachment da ex-presidente foi aceito pelo presidente da Câmara, Eduardo Cunha. Os maiores protestos contra o governo ocorreram

\footnotetext{
${ }^{7}$ A operação Lava Jato é a maior investigação de corrupção e lavagem de dinheiro que o Brasil já teve. Estima-se que o volume de recursos desviados dos cofres da Petrobras, maior estatal do país, esteja na casa de bilhões de reais. Soma-se a isso a expressão econômica e política dos suspeitos de participar do esquema de corrupção que envolve a companhia.

No primeiro momento da investigação, desenvolvido a partir de março de 2014, perante a Justiça Federal em Curitiba, foram investigadas e processadas quatro organizações criminosas lideradas por doleiros, que são operadores do mercado paralelo de câmbio. Depois, o Ministério Público Federal recolheu provas de um imenso esquema criminoso de corrupção envolvendo a Petrobras (BRASIL, [s.d.]).
} 
em março de 2016, mesmo período em que a delação premiada de Delcídio Amaral estimula o processo de impeachment, com acusações a Dilma. Assim, o processo foi aprovado no Senado em maio de 2016, com 55 votos a favor e 22 contra (O GLOBO, 2016).

Com o impeachment da ex-presidente Dilma, em 12 de maio do ano de 2016, tomou posse como presidente interino do Brasil, o senhor Michel Temer, que até então ocupava o cargo de vice-presidente. Após tal mudança governamental, as políticas públicas de desenvolvimento rural, que foram construídas de forma participativa e visando a inclusão social, passaram a ser desmanteladas (MATTEI, 2016). Um exemplo de política que sofreu alterações com o impeachment é o Programa Mais Gestão, que foi descontinuado pela revogação da Chamada Pública n ${ }^{\circ}$ 02/2016 em 10 de junho do ano de 2016, pela Secretaria Especial da Agricultura Familiar (BRASIL, 2016g).

Orientada pelo modelo analítico proposto por Kingdon (2006a) e analisado por Souza e Secchi (2015), a presente pesquisa utilizou a análise de fluxos de problemas, soluções e do ambiente político para compreender a extinção do Programa Mais Gestão, guiada pelas decisões políticas que ocorreram no Brasil a partir de 2016. Mesmo que a extinção de um programa nem sempre seja considerada como algo negativo, pois, durante a etapa de avaliação, caso os objetivos de determinado programa tenham sido atendidos e seus problemas solucionados, pode ser que o ciclo tenha fim (TREVISAN; BELLEN, 2008). Questiona-se, portanto, sobre o que provocou a descontinuidade do PMG.

No mesmo dia da aprovação do impeachment e a posse do novo presidente interino foi publicada a Medida Provisória 726 (MP 726) (posteriormente convertida na Lei $\mathrm{n}^{\circ}$ 13.341, de 29 de setembro de 2016) que extinguiu o Ministério do Desenvolvimento Agrário (MDA). O referido Ministério era protagonista de inúmeras políticas públicas destinadas aos segmentos sociais rurais até então excluídos. As ações focavam os povos e comunidades tradicionais, quilombolas, negros, políticas de gênero, de juventude, indígenas e outros (MATTEI, 2016).

No Quadro 3 estão expostas as principais medidas legislativas após o impeachment: 
Quadro 3 - Principais medidas legislativas adotadas pelo Presidente Michel Temer.

\begin{tabular}{|c|c|c|}
\hline Instrumento & Ementa & Situação \\
\hline $\begin{array}{c}\text { MP n } 726 \\
\text { de } 12 / 05 / 2016\end{array}$ & $\begin{array}{c}\text { Altera a organização da Presidência da República e dos } \\
\text { Ministérios, extinguindo o Ministério do Desenvolvimento } \\
\text { Agrário }\end{array}$ & $\begin{array}{l}\text { Convertida na } \\
\text { Lei }{ }^{\circ} 13.341 \text { de } \\
29 / 09 / 2016\end{array}$ \\
\hline $\begin{array}{l}\text { Decreto } n^{\circ} \\
8780 \text { de } \\
27 / 07 / 2016\end{array}$ & $\begin{array}{c}\text { Transfere a Secretaria Especial de Agricultura Familiar e do } \\
\text { Desenvolvimento Agrário para a Casa Civil. }\end{array}$ & $\begin{array}{l}\text { Regovado pelo } \\
\text { Decreto } \mathrm{n}^{\circ} 8865 \\
\text { de } 29 / 09 / 2016\end{array}$ \\
\hline $\begin{array}{l}\text { Decreto } \mathrm{n}^{\circ} \\
8786 \text { de } \\
14 / 05 / 2016\end{array}$ & $\begin{array}{l}\text { Subordina a estrutura do extinto MDA ao Ministro de Estado } \\
\text { Chefe da Casa Civil }\end{array}$ & $\begin{array}{l}\text { Regovado pelo } \\
\text { Decreto }{ }^{\circ} 8865 \\
\text { de } 29 / 09 / 2016\end{array}$ \\
\hline $\begin{array}{l}\text { MP n }{ }^{\circ} 728 \text { de } \\
23 / 05 / 2016\end{array}$ & $\begin{array}{c}\text { Revoga dispositivos da MP } \mathrm{n}^{\circ} 726 \text {, de } 12 \text { de maio de } 2016 \text { entre } \\
\text { outras medidas }\end{array}$ & $\begin{array}{l}\text { Convertida na } \\
\text { Lei }{ }^{\circ} 13.345 \text { de } \\
10 / 10 / 2016\end{array}$ \\
\hline $\begin{array}{l}\text { Decreto } \mathrm{n}^{\circ} \\
8.780 \text { de } \\
27 / 05 / 2016\end{array}$ & Transfere a SEAD para a Casa Civil & \\
\hline $\begin{array}{l}\text { Decreto } \mathrm{n}^{\circ} \\
8.865 \text { de } \\
29 / 09 / 2016\end{array}$ & $\begin{array}{l}\text { Transfere a SEAD para a Casa Civil e dispõe sobre a vinculação } \\
\text { do INCRA }\end{array}$ & \\
\hline $\begin{array}{l}\text { Decreto } n^{\circ} \\
8889 \text { de } \\
26 / 10 / 2016\end{array}$ & $\begin{array}{l}\text { Aprova a Estrutura Regimental e o Quadro Demonstrativo dos } \\
\text { Cargos em Comissão e das Funções de Confiança da Casa Civil }\end{array}$ & $\begin{array}{l}\text { Alterado pelo } \\
\text { Decreto } \mathrm{n}^{\circ} 9157 \\
\text { de } 12 / 09 / 2017\end{array}$ \\
\hline $\begin{array}{l}\text { MP n }{ }^{\circ} 759 \text { de } \\
22 / 12 / 2016\end{array}$ & Dispõe sobre a regularização fundiária rural e urbana & $\begin{array}{l}\text { Convertida na } \\
\text { Lei } \mathrm{n}^{\circ} 13.465 \text { de } \\
11 / 07 / 2017\end{array}$ \\
\hline $\begin{array}{l}\text { Decreto } n^{\circ} \\
9.004 \text { de } \\
13 / 03 / 2017\end{array}$ & $\begin{array}{l}\text { Transfere a Secretaria de Aquicultura e Pesca do Ministério da } \\
\text { Agricultura, Pecuária e Abastecimento e dá outras providências. }\end{array}$ & \\
\hline $\begin{array}{l}\text { Decreto } \mathrm{n}^{\circ} \\
9.064 \text { de } \\
31 / 05 / 2017\end{array}$ & $\begin{array}{l}\text { Dispõe sobre a Unidade Familiar de Produção Agrária, institui o } \\
\text { Cadastro Nacional da Agricultura Familiar e regulamenta a Lei no } \\
\text { 11.326, de } 24 \text { de julho de } 2006 \text {, que estabelece as diretrizes para a } \\
\text { formulação da Política Nacional da Agricultura Familiar e } \\
\text { empreendimentos familiares rurais. }\end{array}$ & \\
\hline $\begin{array}{l}\text { MP n }{ }^{\circ} 782 \text { de } \\
31 / 05 / 2017\end{array}$ & $\begin{array}{c}\text { Estabelece a organização básica dos órgãos da Presidência da } \\
\text { República e dos Ministérios. }\end{array}$ & $\begin{array}{c}\text { Convertida na Lei } \\
\mathrm{n}^{\circ} 13.502 \text { de } \\
01 / 11 / 2017\end{array}$ \\
\hline $\begin{array}{l}\text { Decreto } \mathrm{n}^{\circ} \\
9.186 \mathrm{de} \\
01 / 11 / 2017\end{array}$ & $\begin{array}{l}\text { Dispõe sobre a composição, a estruturação, as competências e o } \\
\text { funcionamento do Conselho Nacional de Desenvolvimento Rural } \\
\text { Sustentável. }\end{array}$ & \\
\hline
\end{tabular}

Fonte: Cabral (2017).

Essas medidas provisórias são as que mais afetaram aos agricultores familiares, tendo relação direta com as políticas públicas para essa classe. 


\section{Fluxo de problemas}

Os governos anteriores (Lula e Dilma) deram grande atenção e relevância a classes até então aquém do interesse governamental, como os agricultores familiares. O Plano Safra da Agricultura Familiar, dos anos 2016-2017, foi o responsável por lançar a Chamada Pública n 02/2016 para dar continuidade ao Programa Mais Gestão. No entanto, conforme aponta Mattei (2016, p. 11), um dos primeiros atos do Secretário Especial de Agricultura familiar foi revogar tal chamada, "ficando clara a mudança de rumo das políticas públicas para o meio rural sob a batuta do governo interino".

No Plano Safra, estavam previstos $\mathrm{R} \$ 500$ milhões, com $\mathrm{R} \$ 170$ milhões já autorizados pela ex-presidente Dilma Rousseff. Porém, no dia 31 de maio do ano de 2016, o Ministério do Desenvolvimento Social e Agrário (MDSA) "cancelou o repasse desses recursos para a Companhia Nacional de Abastecimento (CONAB)" (MATTEI, 2016, p. 11). Tal ação demonstra uma considerável redução na atenção aos problemas condizentes a agricultura familiar, segurança alimentar, promoção do desenvolvimento rural e ações focadas a povos historicamente excluídos.

Além da revogação da chamada para contratação das entidades de ATER, algumas outras ações do governo interino comprovam a redução da atenção a essas problemáticas, como por exemplo: modificações no Programa Nacional de Habitação Rural (PNHR), que só não foi extinto devido a pressões de organizações sociais e sindicais, cristalização da construção de uma nova proposta de ATER para o país, associado à demissão do Presidente da Agência Nacional de Assistência Técnica e Extensão Rural (ANATER) e outras (MATTEI, 2016). Afetando ainda mais as ações de ATER, o recurso orçamentário destinado foi reduzido em 11,8\%, sendo de $\mathrm{R} \$ 235.221 .780,00$ e $\mathrm{R} \$ 207.548 .191,00$, em 2017 e 2018, respectivamente (CABRAL, 2017).

Essas ações refletem a mudança de preocupação do governo. As políticas com foco para a agricultura familiar, ativa na economia do país e fundamental na produção de alimentos e geração de renda, já não eram mais prioridade na agenda governamental. A descontinuidade de algumas políticas não foi gerada após a superação dos problemas que as originaram, pelo contrário, a descontinuidade pode agravar ainda mais a situação das populações vulneráveis (CABRAL, 2017). 


\section{Fluxo de soluções}

Com o impeachment e a extinção do MDA, todas as atividades desse ministério foram fundidas com as do Ministério do Desenvolvimento Social (MDS), que passa a ser denominado Ministério do Desenvolvimento Social e Agrário (MDSA). A estrutura institucional e suas autarquias, como o Instituto de Colonização e Reforma Agrária (INCRA) foram transferidas para o MDSA, com vistas a integrar os aspectos social e agrário. Vinculado ao MDSA foi instituída a "Secretaria Especial de Agricultura Familiar e do Desenvolvimento Agrário, a qual agrega as seguintes secretarias: Secretaria da Agricultura Familiar (SAF); Secretaria de Reordenamento Agrário (SRA); Secretaria de Desenvolvimento Territorial (SDT); e Secretaria de Regularização Fundiária na Amazônia Legal” (MATTEI, 2016, p. 9). No entanto, com a medida provisória $\mathrm{n}^{\circ} 782$, de maio de 2017, o Órgão passa a ser nomeado como Ministério do Desenvolvimento Social.

Tal medida aponta para uma incorporação de políticas públicas, ou seja, mesmo sem a avaliação de fato do Programa Mais Gestão, as políticas públicas que focavam às organizações da agricultura familiar agora disputam "espaço com outras temáticas", e possivelmente uma integração das políticas. Embora seja necessária a sinergia dos programas e políticas públicas, integrar temáticas em uma espécie de secretaria única, indica que essas temáticas não são prioridades na agenda política.

\section{Fluxo político}

As divergências políticas entre os integrantes dos ministérios e as forças do governo interino provocaram novas alterações nas estruturas ministeriais. Em 27 de maio de 2017, o então Presidente Michel Temer publicou um novo decreto, transferindo a Secretaria Especial de Agricultura Familiar e do Desenvolvimento Agrário para a Casa Civil da Presidência da República. Desse modo, a "reforma agrária, de promoção do desenvolvimento sustentável do segmento rural constituído pelos agricultores familiares e à delimitação das terras dos remanescentes das comunidades dos quilombos e à determinação de suas demarcações" passam a ser de competência da Casa Civil da Presidência da República (BRASIL, 2016h; MATTEI, 2016).

Conforme indica Mattei (2016, p. 9), essa modificação foi uma “demanda política do Partido Solidariedade, liderada pelo deputado federal Paulinho Pereira da Silva (Paulinho da Força Sindical)”. O deputado foi responsável por indicar as primeiras 
nomeações da nova secretaria: a presidência do INCRA e diretorias do órgão; o secretário especial da agricultura familiar; o diretor da ANATER e o cargo de secretário adjunto de agricultura familiar (DECAT, 2016; MATTEI, 2016).

Diante do exposto, em analogia ao proposto por Souza e Secchi (2015), a mudança da presidência do Brasil, que antes era presidido por uma petista e passou a ser governado por um membro do Partido do Movimento Democrático Brasileiro (PMDB), atrelada à redução da atenção às classes historicamente excluídas e mudanças estruturais em uma intenção de integrar políticas públicas, possibilitou a extinção do Programa Mais Gestão. Mesmo sendo um programa inovador, que visava melhoria de gestão para as cooperativas de agricultura familiar acessarem a mercados institucionais, não foi possível mantê-lo entre as ações prioritárias para o novo governo.

A extinção do Programa confere com a constatação de Bardach (1976). Sobre a existência de três atores que podem promover a extinção de um programa: os opositores, que simplesmente estão em desacordo com o proposto; os economistas, que visam reduzir gastos; e por fim os reformadores que enxergam essa extinção como a possibilidade de propor uma nova política. Desse modo, o governo presidido por Michel Temer reduziu o orçamento de diversos programas com a justificativa de redução de gastos, amparado no discurso do sacrifício de alguns setores da economia, dentre os quais aqueles ligados a proteção social e inclusão produtiva de agricultores familiares foram os principais.

Inúmeras mudanças realizadas durante o governo do Presdente Michel Temer, como a extinção de instituições e programas provoca a emergência de novas lutas políticas. Essas mudanças fortalecem os interesses dos grandes capitais em detrimento aos pequenos e médios empreendimentos, por meio da restrição ao acesso dos direitos fundamentais e políticas sociais (MATTOS, 2017).

Com relação ao Plano Safra, Cabral faz uma análise dos pronunciamentos dos dois presidentes: Dilma Rousseff e Michel Temer. O autor aponta que o pronunciamento da ex-presidente Dilma contava com atenção aos movimentos sociais da agricultura familiar, por outro lado, o pronunciamento do presidente Michel Temer dava destaque a titulação dos lotes de reforma agrária e a agricultura familiar apenas como produtora de alimentos (CABRAL, 2017). 


\section{A descontinuidade e um considerável valor investido}

Conforme exposto no capítulo anterior, foram investidos $\mathrm{R} \$ 71.692 .438,17$ para a execução das quatro chamadas públicas do Programa Mais Gestão.

(1) Chamada $04 \mathrm{R} \$ 25.026 .700,82$ com aproximadamente $\mathrm{R} \$ 3$ milhões por lote (7 lotes).

(2) Chamada $06 \mathrm{R} \$ 37.607 .053,88$ com valores diferenciados para cada lote, de quase R\$ 3 milhões a mais de R \$ 6 milhões (9 lotes).

(3) Chamada $07 \mathrm{R} \$ 4.154 .112,94$ com o mesmo valor para cada lote $\mathrm{R} \$$ 2.077.056,47 (2 lotes).

(4) Chamada $17 \mathrm{R} \$ 4.904 .570,53$ com investimento de $\mathrm{R} \$ 3.448 .634,21$ para o lote 1 e $\mathrm{R} \$ 1.455 .936,31$ para o lote 2 .

Com um montante de mais de $\mathrm{R} \$ 70$ milhões investidos, 448 cooperativas assistidas em 18 estados, o Programa Mais Gestão avançou na oferta de ATER para cooperativas da agricultura familiar, um setor que carecia de auxílios. No entanto, os resultados do Programa não são passíveis de avaliação, pois, sua duração foi consideravelmente curta (2012 a 2015).

A priori, os beneficiários diretos (cooperativas de agricultura familiar) foram os mais afetados com a descontinuidade do Programa. No entanto, é possível observar algumas outras reações a partir dessa decisão. As entidades de ATER que até então poderiam trabalhar para o Mais Gestão não possuem mais essa fonte de trabalho e, além disso, com a interrupção da assistência para as organizações, estas passam a enfrentar novamente dificuldades de acesso ao mercado institucional.

Uma reflexão necessária é sobre qual retorno esse investimento trouxe para a sociedade brasileira. Embora o tempo de execução do Programa não permita que seja realizada uma avaliação completa do mesmo, é importante indagar se ele atingiu seu objetivo proposto. E mais, com a descontinuidade do Programa Mais Gestão, aliada a redução de verbas para as políticas sociais, os agricultores familiares conitnuarão a acessar os mercados institucionais?

Além das questões já citadas, outras questões merecem atenção especial dos formuladores de políticas para a agricultura familiar. Com a redução do enfoque às 
políticas públicas voltadas para a agricultura familiar, encabeçada pela extinção do MDA, alguns efeitos preocupantes podem ocorrer, como:

recrudescimento da violência no campo, aumento do êxodo rural, empobrecimento massivo da população rural, redução drástica da produção de alimentos ao mercado de consumo doméstico e riscos de perda de garantia da soberania e segurança alimentar e nutricional da sociedade brasileira (MATTOS, 2017, p. 4).

Como apontou Cabral (2017) o Projeto de Lei Orçamentária (PLO) enviado pelo Presidente Temer ao Congresso Nacional para o ano de 2018, apontou reduções no orçamento para a SEAD e o MDS, afetando diretamente o PAA. Nesse aspecto, a descontinuidade de um programa sinérgico, como o Programa Mais Gestão, associada à redução orçamentária para diversas políticas, aponta para a necessidade de maior atenção aos problemas dos agricultores familiares. 


\section{Breves considerações}

É possível perceber, após a análise da extinção repentina do Programa Mais Gestão que o mesmo foi encerrado após alterações governamentais. A descontinuidade de programas que beneficiavam aos agricultores familiares e camponeses, assentados e segmentos historicamente segregados, foi provocada após o impeachment da expresidente Dilma Rousseff (MATTEI, 2016; MATTOS, 2017).

Após a identificação de cada fluxo foi possível observar que o fluxo político foi responsável por desencadear as principais mudanças durante a descontinuidade do Programa Mais Gestão. Com a mudança governamental, as ações políticas visavam a incorporação de soluções e programas, o que indica a alteração no olhar sob os problemas, baseada na proposta de redução de custos.

Como explicou Cabral (2017), a mudança na agenda das políticas públicas para a agricultura familiar não poderia ser caracterizada como um problema caso as políticas descontinuadas fossem substituídas por outras. O que deve ser levado em conta é que as políticas desestruturadas não estão sendo substituídas e além disso, os recursos voltados para os agricultores familiares e outros pequenos produtores rurais bem como políticas sociais vêm sendo reduzidos consideravelmente. 


\section{CONSIDERAÇÕES FINAIS}

O Programa Mais Gestão é resultado de esforços governamentais ancorados em um novo paradigma: a ATER coletiva, voltada para organizações cooperativas de agricultura familiar. Essa mudança de paradigma é uma das principais inovações do programa, que durante sua execução atendeu mais de 400 cooperativas.

A relevância do programa, porém, não está limitada apenas a essa ruptura de paradigma. O PMG foi capaz também de provocar mudanças na instituição que o promoveu, o MDA. Conforme Sousa (2015), o Mais Gestão foi fundamental para a criação da Coordenação de Cooperativismo no extinto Ministério, potencializando as atenções para tais organizações.

O objetivo dessa dissertação não foi, portanto, discutir se a administração pública brasileira provoca ou não a descontinuidade de políticas públicas, mas sim, compreender e registrar como se deu o processo de descontinuidade de um programa inovador e que foi descontinuado logo após o lançamento de uma nova chamada pública.

É importante ressaltar que conforme apontam Souza e Secchi (2015), a descontinuidade não é necessariamente um fator negativo para a política, a descontinuidade pode significar que o problema responsável por gerar tal política foi sanado. O que intriga e que foi questão central para o desenvolvimento dessa pesquisa, foi entender o porquê do PMG ter sido descontinuado, sem ao menos ter tido tempo para uma avaliação. Como questiona Brewer (1974), como um programa pode ser ajustado ou parado sem ter tido uma avaliação completa?

Embora uma política pública a qual o PMG está inserido, como a ATER, não tenha sido descontinuada (mesmo que tenha sofrido diversas reduções de recurso), o PMG, como mecanismo para fomentar a qualificação das cooperativas foi encerrado, acarretando perdas severas. O reconhecimento da extinção repentina do Programa, que ocasionou a não conclusão de etapas previstas em sua gênese, permite que seja levantada a hipótese de que o governo interino pouco pretende utilizar das contribuições desse Programa.

A descontinuidade desse Programa pôde ser explicada pelos fluxos múltiplos criados por Kingdon (2006a). Dentre os fluxos múltiplos, o fluxo político foi o que teve maior relevância e que deu o pontapé para todas as mudanças governamentais, iniciadas com a troca presidencial. 
Com relação ao fluxo de problemas, é nítida a mudança no foco dos problemas governamentais. Anteriormente, durante os governos petistas, as ações e políticas públicas buscavam aperfeiçoar e promover os agricultores familiares, no entanto, a redução da atenção aos problemas voltados para a agricultura familiar é evidente nas modificações das políticas e também na redução do recurso orçamentário.

No que concerne o fluxo de soluções, foi observada uma tentativa de incorporação de políticas públicas ao se criar a Secretaria Especial da Agricultura Familiar e do Desenvolvimento Agrário - SEAD, no âmbito da Casa Civil. As políticas para a agricultura familiar, desenvolvimento territorial e reforma agrária, além de outras, agora disputam espaço com outra temáticas (CABRAL, 2017).

Mesmo não sendo objetivo desta dissertação, alguns levantamentos são necessários e possíveis de se realizar. Em primeiro lugar, mesmo com todas as inovações apontadas, o PMG foi criado sem um planejamento prévio, "a roda do carro foi trocada com o carro em movimento". Além disso, pela concepção do Programa e objetivos, pode-se inferir que o MDA visava atender cooperativas melhor estruturadas e com ajustes finos a se realizar para acesso a mercados institucionais, porém, foi encontrado o contrário pelos agentes de ATER em campo.

Indagações surgem diante de toda a pesquisa. Mesmo sem uma avaliação para indicar a efetividade do Programa, é possível questionar a assertividade em se descontinuar o Programa Mais Gestão, frente a seu alcance e recursos investidos. Por outro lado, se o Programa se demonstra tão inovador, não seriam necessários apenas alguns ajustes para aprimorar o PMG e melhor atender as organizações de agricultura familiar? Essas ações poderiam ter sido realizadas caso o Programa não tivesse sido descontinuado, visto que a Rede de Universidades poderia ter concluído sua avaliação, indicando possíveis ajustes e melhorias para o MDA.

Ampliando ainda mais o campo de questões, pergunta-se se somente os cooperados serão afetados por conta da descontinuidade do Programa. A priori, vê-se apenas que os agricultores e as entidades de ATER sofrerão com esta descontinuidade. No entanto, esse encerramento pode desencadear que as cooperativas não consigam acessar novamente os mercados, diminuindo a oferta para os programas citados na pesquisa. 
Essas questões, portanto, são alguns questionamentos que abrem portas para novas pesquisas. Diante do exposto, a dissertação elaborada não possui o intuito de esgotar a hipótese sugerida, mas sim abrir caminhos e possibilidades para novos estudos. 


\section{REFERÊNCIAS}

AMELIA, M. et al. Análise da inclusão da agricultura familiar na alimentação escolar no estado de São Paulo. 2012.

AVILA, M. L. et al. Nova Lei De Ater E Inovações Em Políticas Públicas: O Caso

Do Programa Mais Gestão. Brasília: [s.n.]. Disponível em:

$\langle$ http://icongresso.itarget.com.br/useradm/anais/?clt=ann.2\&lng=P>.

AVILA, M. L.; CALDAS, E. DE L.; ASSAD, S. S. Sinergia e coordenação em políticas públicas : o caso do PAA e PNAE. Sociedade e Desenvolvimento Rural, v. 7, n. 3, p. 68-81, 2013.

BARDACH, E. Policy Termination as a Poliical process. v. 7, n. 2, p. 123-131, 1976.

BONDUKI, M. R. P. C. Entre chicotes e cenouras orgânicas: cooperação, coerção e coordenação na implementação das compras da agricultura familiar para o PNAE. [s.l.] Escola de Administração de Empresas de São Paulo, 2017.

BRASIL. Modalidades do PAA | Secretaria Especial de Agricultura Familiar e do Desenvolvimento Agrário. Disponível em:

<http://www.mda.gov.br/sitemda/secretaria/saf-paa/modalidades-do-paa $>$. Acesso em: 21 ago. 2017a.

BRASIL. Lei no 11.326, de 24 de julho de 2006Presidência da República, , 2006 a.

Disponível em: <http://www.planalto.gov.br/ccivil_03/_Ato20042006/2006/Lei/L11326.htm>. Acesso em: 21 ago. 2017

BRASIL. Lei $\mathbf{N}^{\circ}$ 11.947, de 16 de junho de 2009.Planalto, 2009. Disponível em: <http://www.planalto.gov.br/ccivil_03/_ato2007-2010/2009/lei/111947.htm>. Acesso em: 4 jan. 2018

BRASIL. Lei $\mathbf{N}^{\circ}$ 12.515, de 14 de Outubro de 2011Presidência da República, , 2011. Disponível em: <http://www.planalto.gov.br/ccivil_03/_Ato20112014/2011/Lei/L12512.htm\#art33>. Acesso em: 21 ago. 2017

BRASIL, C. C. Diagnóstico das cooperativas atendidas pelo Programa ATER Mais Gestão: análise exploratória. Brasília: [s.n.].

BRASIL, C. C. Relatório sobre a dimensão normativa do Programa Mais Gestão 
do MDA e Relatório final do estudo exploratório realizado nos estados da Paraíba, Pernambuco e Rio Grande do Norte. Brasil: [s.n.].

BRASIL, F. Superação da fome e da pobreza rural: iniciativas brasileiras. Brasília: [s.n.].

BRASIL, F. Cooperativismo da agricultura familiar e a economia solidário. In:

Organização das Nações Unidas para a Alimentação e a Agricultura (FAO).

Brasília: [s.n.]. p. 103-117.

BRASIL, F. Romper o ciclo da pobreza rural. In: Superação da fome e da pobreza: iniciativas brasileiras. Brasília: [s.n.]. p. 1-11.

BRASIL, F. N. DE D. DA E. (FNDE). Sobre o PNAE. Disponível em: <http://www.fnde.gov.br/programas/pnae>. Acesso em: 3 nov. 2017 b.

BRASIL, I. Censo Agropecuário 2006: agricultura familiar primeiros resultados. Rio de Janeiro: [s.n.]. Disponível em:

$<$ https://biblioteca.ibge.gov.br/visualizacao/periodicos/50/agro_2006_agricultura_famili ar.pdf>. Acesso em: 27 nov. 2017 b.

BRASIL, M. Programa Nacional de Produção e Uso de Biodiesel: inclusão social e desenvolvimento territorial. Brasília: [s.n.].

BRASIL, M. Termo de execução descentralizada $\mathbf{N}^{\circ}$ 046/2014, 2014a. Disponível em: <http://www.mda.gov.br/sitemda/sites/sitemda/files/user_img_19/TED 046-2014 SAF-MDA-UFV-MG - Instituir e articular a Rede Mais Gestão de Universidades\%2C estimulando o desenvolvimento de processos de monitoram>. Acesso em: 26 set. 2017 BRASIL, M. PAA: 10 anos de aquisição de alimentos. Brasília: MDS; Secretaria Nacional de Segurança Alimentar e Nutricional; Secretaria de Avaliação e Gestão da Informação, 2014b.

BRASIL, M. Chamada pública para seleção de entidades executoras de ATER para qualificação da gestão, apoio ao fortalecimento e à inserção de organizações econômicas da agricultura familiar nos mercados institucionais, públicos e privados, $2016 f$.

BRASIL, M. P. F. Entenda o caso - Caso Lava Jato. Disponível em: <http://www.mpf.mp.br/para-o-cidadao/caso-lava-jato/entenda-o-caso>. Acesso em: 7 nov. $2017 \mathrm{~d}$. 
BRASIL, P. DA R. Lei no 11.097, de 13 de janeiro de 2005, 2005. Disponível em: <http://www.planalto.gov.br/ccivil_03/_Ato2004-2006/2005/Lei/L11097.htm\#art2>. Acesso em: 17 nov. 2017

BRASIL, P. DA R. Lei n ${ }^{\circ}$ 13.033, de 24 de setembro de 2014, 2014c. Disponível em: <http://www.planalto.gov.br/ccivil_03/_Ato2011-2014/2014/Lei/L13033.htm\#art6>. Acesso em: 17 nov. 2017

BRASIL, P. DA R. Diário Oficial da UniãoBrasil, 2016g. Disponível em: <https://www.jusbrasil.com.br/diarios/117823465/dou-secao-3-10-06-2016-pg-2> BRASIL, P. DA R. Decreto ${ }^{\circ}$ 8.780, de 27 de maio de 2016, 2016h. Disponível em: <http://www2.camara.leg.br/legin/fed/decret/2016/decreto-8780-27-maio-2016-783152publicacaooriginal-150428-pe.html>

BRASIL, S. Painel de políticas. Disponível em: <http://nead.mda.gov.br/politica/localidade/>. Acesso em: 27 nov. 2017a.

BRASIL, S. Ater Mais Gestão: 23 cooperativas beneficiadas em oito estados | Secretaria Especial de Agricultura Familiar e do Desenvolvimento Agrário. Disponível em: <http://www.mda.gov.br/sitemda/noticias/ater-mais-gestão-23cooperativas-beneficiadas-em-oito-estados>. Acesso em: 27 set. $2017 \mathrm{~b}$.

BRASIL, S. E. DE A. F. E DO D. A. Acompanhe as ações do MDA e INCRA | Secretaria Especial de Agricultura Familiar e do Desenvolvimento Agrário. Disponível em: <http://www.mda.gov.br/sitemda/pagina/acompanhe-ações-do-mda-eincra>. Acesso em: 25 nov. 2017c.

BREWER, G. D. The policy sciences emerge: To nurture and structure a discipline. Policy Sciences, v. 5, n. 3, p. 239-244, set. 1974.

CABRAL, P. G. As mudanças na agenda das políticas públicas para a agricultura familiar promovidas pelo Governo Temer. Mestrado em Ciências Sociais do Desenvolvimento, Agricultura e Sociedade, p. 36, 2017.

CALDAS, E. DE L. Formação de agendas governamentais locais : o caso dos consórcios intermunicipais. [s.1.] Faculdade de Filosofia, Letras e Ciências Humanas da Universidade de São Paulo, 2007.

CALDAS, E. DE L.; ÁVILA, M. L. Continuidade de políticas públicas e o caso do Programa Nacional de Alimentação Escolar (PNAE). v. 13, n. 148, p. 77-84, 2013. 
CAMPOS, A.; BIANCHINI, V. A Agricultura Familiar passa a ser uma prioridade de Estado. In: PAA: 10 anos de aquisição de alimentos. [s.l: s.n.]. p. 10-25.

CAPELLA, A. C. N. Perspectivas Teóricas sobre o Processo de Formulação de Políticas Públicas. Revista Brasileira de Informação Bibliográfica em Ciências Sociais, v. 61, p. 25-52, 2006.

CAPELLA, A. C. N. Análise de políticas públicas: da técnica às ideias. Idéias - Rev. Inst. Filos. Ciênc. Hum. UNICAMP, 2015.

CARVALHO, F. J. C. DE. Keynes e o Brasil. Economia e Sociedade, v. 17, n. spe, p. 569-574, dez. 2008.

CONAB, C. N. DE A. Programa de Aquisição de Alimentos - PAA: resultados das ações da Conab em 2016. Brasília: [s.n.]. Disponível em:

<http://www.conab.gov.br/OlalaCMS/uploads/arquivos/17_07_18_14_41_42_compend io.pdf>. Acesso em: 13 nov. 2017.

CRESWELL, J. W. Projeto de pesquisa: métodos qualitativo, quantitativo e misto. 2. ed. Porto Alegre: [s.n.].

DECAT, E. Paulinho da Força "nomeia" titulares da área agrária. Disponível em: $<$ http://politica.estadao.com.br/noticias/geral,paulinho-da-forca-nomeia-titulares-daarea-agraria,10000054548>. Acesso em: 17 ago. 2017.

DELEON, P. Policy evaluation and program terminationSanta Monica, 1982.

Disponível em: <https://www.rand.org/content/dam/rand/pubs/papers/2008/P6807.pdf>. Acesso em: 20 nov. 2017

DELGADO, G. C.; BERGAMASCO, S. M. P. P. Agricultura familiar brasileira: desafios e perspectivas de futuro. Brasília: [s.n.].

E10, E. Entrevista E10. Brasília. Áudio: Entrevista concedida a Rede de Universidades na Avaliação do Programa Mais Gestão. 2015.

E14, E. Entrevista E14. Brasília. Áudio: Entrevista concedida a Rede de Universidades na Avaliação do Programa Mais Gestão. 2015.

E16, E. Entrevista E16. Brasília. Áudio: Entrevista concedida a Rede de Universidades na Avaliação do Programa Mais Gestão. 2015.

E6, E. Entrevista E6. Brasília. Áudio: Entrevista concedida a Rede de Universidades 
na Avaliação do Programa Mais Gestão. 2015.

ESTEVAM, D. DE O. A contínua descontinuidade administrativa e de políticas públicas. II Seminário das Ciências Sociais Aplicadas, p. 14, [s.d.].

FORNAZIER, A.; BELIK, W. Inserção dos produtores familiares no mercado de alimentos para a alimentação escolar. Anais do Evento Seminário Nacional Sociologia \& Política, v. 11, p. 21, 2011.

GIL, A. C. Métodos e técnicas de pesquisa social. 6. ed. São Paulo: [s.n.].

GRISA, C. As políticas públicas para a agricultura familiar no Brasil: um ensaio a partir da abordagem cognitiva. v. 831, n. 2, p. 83-109, 2010.

GRISA, C. Políticas públicas para a Agricultura Familiar no Brasil: produção e institucionalização das ideias. [s.l.] Universidade Federal Rural do Rio de Janeiro, 2012.

GRISA, C. (ORG. .; SCHNEIDER, S. (ORG. . Políticas públicas de desenvolvimento rural no Brasil. 1. ed. Porto Alegre: [s.n.].

GRISA, C.; SCHNEIDER, S. Três gerações de políticas públicas para a agricultura familiar e formas de interação entre sociedade e Estado no Brasil. In: Políticas públicas de desenvolvimento rural no Brasil. Editora da ed. Porto Alegre: [s.n.]. p. 19-50.

GRISA, C.; WESZ JUNIOR, V. J.; BUCHWEITZ, V. D. Revisitando o Pronaf: velhos questionamentos, novas interpreta??es. Revista de Economia e Sociologia Rural, v. 52, n. 2, p. 323-346, jun. 2014.

GUTIÉRREZ, J. M. V. Retroalimentando la etapa de terminación: Análisis de casos de políticas públicas. Estudios Políticos, v. 38, p. 163-189, maio 2016.

KINGDON, J. W. Juntando as coisas. In: Políticas públicas. 1. ed. Brasília: ENAP, 2006a. p. 225-245.

KINGDON, J. W. Como chega a hora de uma ideia? In: Políticas públicas. 1. ed. Brasília: ENAP, 2006b. p. 219-224.

LACEY, H. Valores e atividade científica 1. Editora 34 ed. São Paulo: [s.n.].

MALUF, R. S. Prefácio. In: UFRGS, E. DA (Ed.). . Políticas públicas de desenvolvimento rural no Brasil. 1. ed. Porto Alegre: [s.n.]. p. 9-12.

MATTEI, L. Programa Nacional para Produção e Uso do Biodiesel no Brasil (PNPB): 
trajetória, situação atual e desafios. v. 4, p. 731-740, 2010.

MATTEI, L. F. O governo interino e a desestruturação da política agrária e de desenvolvimento rural do país. Núcleo de Estudos de Economia Catarinense, p. 14, 2016.

MATTOS, L. M. DE. Austeridade fiscal e desestruturação das políticas públicas voltadas à agricultura familiar brasileira. Friedrich-Ebert-Stiftung (FES) Brasil, v. 39, p. 43, 2017.

MOLINA, M. C. Políticas públicas. In: Dicionário da educação do Campo. Rio de Janeiro, São Paulo: Escola Politécnica de Saúde Joaquim Venâncio, Expressão Popular, 2012. p. 587-596.

NASCIMENTO, F. R. et al. Desafios da gestão para organizações rurais da agricultura familiar no BrasilIX Iberian Conference on Rural Studies Smart and Inclusive Development in Rural Areas. [s.l: s.n.].

NEVES, D. P. Agricultura familiar. In: POPULAR, E. (Ed.). . Dicionário da educação do Campo. Rio de Janeiro: [s.n.]. p. 34-42.

NOGUEIRA, F. DO A. Continuidade e descontinuidade administrativa em governos locais: fatores que sustentam a ação pública ao longo dos anos. [s.1.] Fundação Getúlio Vargas Escola de Administração de Empresas de São Paulo, 2006.

O GLOBO. Linha do tempo: entenda a crise que culminou no impeachment Jornal O Globo. Disponível em: <https://oglobo.globo.com/brasil/linha-do-tempoentenda-crise-que-culminou-no-impeachment-20015867>. Acesso em: 8 set. 2017. PEREIRA, M. C. DE B. Revolução Verde. In: Dicionário da educação do Campo2. Expressão ed. Rio de Janeiro: [s.n.]. p. 687-691.

PINTO, I. C. DE M. Mudanças nas políticas públicas: a perspectiva do ciclo de política. Revista de Políticas Públicas, v. 12, n. 1, p. 27-36, 2008.

PIRES, V. B. L. Impacto social do Programa Nacional de Produção e Uso do Biodiesel (PNPB) no nordeste: 2008/2013. [s.1.] Universidade de Brasília, Faculdade de Agronomia e Medicina Veterinária, Programa de Pós-graduação em Agronegócio, 2015.

PORTO, S. I. Programa de Aquisição de Alimentos (PAA): política pública de 
fortalecimento da agricultura familiar e da agroecologia no Brasil. [s.1.]

Universidad Internacional de Andalucía, 2014.

PORTO, S. I. Contribuições do PAA e do PNAE à construção da segurança alimentar e nutricional: a experiência brasileira. 1. ed. Rio de Janeiro: [s.n.].

PORTO, S. I. A agroecologia e o Programa de Aquisição de Alimentos (PAA).

Disponível em: <https://www.cartamaior.com.br/?/Editoria/Meio-Ambiente/Aagroecologia-e-o-Programa-de-Aquisicao-de-Alimentos-PAA-/3/36284>. Acesso em: 27 dez. 2017 b.

RUA, M. DAS G. Análise de políticas públicas: conceitos básicos. p. 1-18, [s.d.]. SABOURIN, E. Origens, evolução e institucionalização da política de agricultura familiar no Brasil. Seminário sobre Agricultura Familiar Brasileira, p. 30, 2014.

SABOURIN, E. A disseminação de modelos brasileiros de políticas públicas para a agricultura familiar na América Latina. Brasília: [s.n.]. Disponível em: $<$ http://agritrop.cirad.fr/586172/1/Relatorio técnico cientifico final Projeto TRANSBRASILdocx.pdf>. Acesso em: 28 dez. 2017.

\section{SANTOS NETO, A. A. DOS. Desafios Para a Integração Da Política Territorial} Brasileira Com O Programa De Aquisição De Alimentos ( Paa ): Coalizões Do Território Águas Emendadas. [s.1.] Universidade de Brasília, 2016.

SÃO JOSÉ, J. A. B.; PEREIRA, G. DA P.; OLIVEIRA, M. L. R. O Programa Mais Gestão: impactos para a comercialização das cooperativas de agricultura familiar no Estado de Minas Gerais. Ano Pág, v. 38, n. 19, p. 13, 2017.

SARAVIA, E. Introdução a teoria da política pública. In: Políticas públicas. 1. ed. Brasília: ENAP, 2006. p. 21-42.

SECCHI, L. Políticas públicas: conceitos, esquemas de análise, casos práticos. São Paulo: Cengage Learning, 2010.

SILVA, M. G.; DIAS, M. M.; AMORIM JUNIOR, P. C. G. Mudanças organizacionais em empreendimentos de agricultura familiar a partir do acesso ao Programa Nacional de Alimentação Escolar. Revista de Economia e Sociologia Rural, v. 53, n. 2, p. 289304, jun. 2015.

SILVA, M. S. et al. Biodiesel e políticas públicas: uma análise crítica do PNPB e das 
políticas do setor agroenergético no estado da Bahia. RDE - Revista de Desenvolvimento Econômico, v. 16, n. 30, 2015.

SOUSA, C. S. et al. Mais Gestão: política de desenvolvimento rural para as cooperativas da agricultura familiar brasileiraCadernos de Agroecologia. Brasília: [s.n.]. Disponível em: <http://abaagroecologia.org.br/revistas/index.php/cad/issue/view/80>. SOUSA, C. S. Análise da concepção do Programa Mais Gestão: entre desenvolvimento e desafios. [s.1.] Universidade de Brasília, 2015. SOUZA, C. Políticas públicas: uma revisão de literatura. Sociologias, v. 8, n. 16, p. 2045, 2006.

SOUZA, D. F. DE. Considerações a respeito da estratégia da SAF/MDA de qualificar a gestão dos empreedimentos da Agricultura Familiar: foco na Metodologia Mais Gestão e Planos de Aprimoramento.Brasília, 2013.

SOUZA, H. Y. DE; SECCHI, L. Extinção de políticas públicas: síntese teórica sobre a fase esquecida do police cycle. Cadernos Gestão Pública e Cidadania, v. 20, n. 20, p. $19,2015$.

SPINK, P. Continuidade e descontinuidade em organizações públicas: um paradoxo democrático. Cadernos FUNDAP, v. 13, p. 9, 1987.

SPINK, P.; CLEMENTE, R.; KEPPKE, R. Continuidade e descontinuidade administrativa: uma análise de fatores que contribuem para a manutenção de programas, projetos e atividades públicas de êxito em governos locais brasileiros. Núcleo de pesquisas e publicações - EAESP/FGV/NPP, p. 62, 1997.

TREVISAN, A. P.; BELLEN, H. M. VAN. Avaliação de políticas públicas : uma revisão teórica de um campo em construção. v. 42, n. 3, p. 529-550, 2008.

UFRB, U. F. DO R. DA B. II Oficina da Rede de Universidades do Projeto Mais Gestão. Disponível em: <https://ufrb.edu.br/ccaab/eventos-1/1265-ii-oficina-da-redede-universidades-do-projeto-mais-gestao>. Acesso em: 1 out. 2017. 